Vanessa Mangione

\title{
Lord Byron's Descendants \\ The Byronic Hero in Lady Caroline Lamb, Charlotte Brontë, and Ellen Wood as a Feminine Critique of Constricting Gender Roles in the Nineteenth Century
}

\section{Introduction}

\subsection{The Byronic Hero}

About three things I was absolutely positive. First, Edward was a vampire. Second, there was a part of him - and I didn't know how potent that part might be - that thirsted for my blood. And third, I was unconditionally and irrevocably in love with him. (Meyer 171)

He closed his eyes, lost in his agonized confession. I listened, more eager than rational. Common sense told me I should be terrified ... [but] I was 
filled with compassion for his suffering, even now, as he confessed his craving to take my life. (Meyer 238)

In 2003, Stephenie Meyer, author of the Twilight Saga, had a dream about a girl and a vampire in a meadow. She turned her dream into a book and became one of the bestselling authors of our time (Lev Grossman). The first book was soon turned into a movie and its male lead, Robert Pattinson, became a star over night. By portraying the mysterious, handsome, guilt-ridden and tortured vampire Edward Cullen, Pattinson strongly evokes characteristics of a well-known literary persona, the Byronic hero. ${ }^{1}$ These characteristics combined with a bitter outlook on the world that has resulted from an incident against which he was powerless and can never break away from are qualities that are commonly connected to the Byronic hero. This persona seems to have struck a chord since it has aroused an intense emotional response within the female readership, precisely as it did back in 1812 when the first Byronic hero appeared in the form of Lord Byron's Childe Harold and won the public over. Henceforth, Byron's heroes dominated the literature of the Romantic period and emerged in numerous variations through the decades. Those heroes are represented in the term of the "Byronic Hero".

The Byronic hero has been a prominent figure in literary fiction since the early nineteenth century and still dominates popular modern romances. He appears, although slightly transformed, in modern vampire fiction, such as Stephenie Meyer's Twilight Saga, in novels by Anne Rice, but also as the dark lover in historical novels by authors like Barbara Cartland, Victoria Holt and Elisabeth Chadwick. They all make excessive use of the tortured hero. He appears in Margaret Mitchell's Gone with the Wind, where he emerges in the shape of Rhett Butler, a dandified version of the original dark lover. During the nineteenth century, the persona of the Byronic hero dominated sensational, Silver fork and Newgate novels. Famous authors like Oscar Wilde, Charles Dickens, Edward Bulwer-Lytton and Benjamin Disraeli are said to have been strongly influenced by Byron's creation and portrayed him in many varying and sometimes opposing forms, as the dark Gothic lover, the soulless seducer or the superficial dandy (Lutz 60).

During the Romantic period, a growing fascination with a wild and melancholy facet of nature arose. Thus the adjective "romantic" does not only refer to a specific literary genre but is attributed to the combination of beautiful and terrifying aspects of nature. Praz advocates in his book The Romantic Agony the thesis that a new erotic sensibility emerged within the Romantic period. According to him, this new sensibility was a perverse one in which contradicting sensations such as tenderness and sadism, pleasure and pain, and love and hate are inseparably connected to each other. Hence, Praz argues that the Romantics took pleasure in the

1 There has always been a notion to link Byron to vampires as Dr. Polidori's, Byron's physician, short story The Vampyre was thought to be written by Byron. Although both confirmed that this was not the case, the connection between Byron and vampires never ceased to be. 
horrid and saw beauty in the bizarre. ${ }^{2}$ Furthermore, he states that an interaction between pleasure and suffering has always existed but "became a common inheritance of the Romantic and Decadent sensibility through a particular chain of literary influences" (Praz xiv). An example of this connection between perverse sensations can be seen in Percy Bysshe Shelley's poem On the Medusa of Leonardo da Vinci: "Tis the tempestuous loveliness of terror" (1. 33). The combination of pleasure and pain is clearly demonstrated in this single line. Suddenly beauty was found in objects that actually should evoke a shudder. ${ }^{3}$

Accordingly, a novel sense of beauty arose which also changed the relationship to horror that was discovered as a new source of beauty and delight. Horror not only became a different form of beauty but also was suddenly one of its indispensable elements. Praz states that the "beautifully horrid" became "horribly beautiful" (27), and although this is not an entirely new concept, as it has existed before, only within the Romantic period has it been recognised and brought to attention. However, the concept of pain as an essential part of desire was entirely new. Another good example of this concept can be found in a different one of Shelley's works To the Skylark: "Our sweetest songs are those that tell of saddest thought" (1. 90). Praz comments on this concept of the sublime: "all through the literature of Romanticism, down to our own times, there is an insistence on this theory of the inseparability of pleasure and pain, and on the practical side, a search for themes of tormented, contaminated beauty" (28).

Within this new concept the Byronic hero was born. This literary persona is described by critics as "fatal homme" (Wilson, Introduction 7), a "passionate hero with a darkly mysterious past" (Elfenbein 9), carrying a burnt-out passion and secret sins ${ }^{4}$ He mainly appears as an immensely proud aristocrat, who tries to hide a secret and sinful past, and his tortured appearance evoked by his remorse is the very thing that attracts women. Furthermore, Thorslev states that he is primarily a lover, his passions are far more subjective and intense than those of other Romantic heroes; love is for him the one ruling passion in his life, on which he bases every other action. The Byronic lover remains faithful to his one and only love until his death. Moreover, Thorslev argues that an air of a fallen angel surrounds this persona, who is on a pilgrimage in search of relief for his past sins, for selfrestoration, although he knows that he will never find what he is seeking and that he will wander in eternal remorse $(136,148-50)$. Pesta adds that Byronic characteristics also include "warmth without light, heat without sun and a burning passion

2 Mentioned here is the sublime, a Romantic concept that describes an idea associated with awe, vastness, natural splendour and glory and strong emotion. It refers to an incomparable magnificence.

3 In A Philosophical Enquiry into the Origin of Our Ideas of the Sublime and Beautiful (1757) Edmund Burke discusses the connection between terror and the sublime and its distinction from beauty. In terror he saw obscurity, darkness, power, vastness, and solitude, while he associated beauty with light, delicacy, smallness and smoothness.

4 This notion characterizes the Romantic concept of love: Love is perpetual longing and pain. 
that is self-consuming in its intensity (62). Lutz agrees with Thorslev that the Byronic hero is primarily a lover; she adds that his whole existence is based on this all-consuming love that will however, never be fulfilled. ${ }^{5}$ Lutz defines the very essence of the Byronic hero most accurately:

The Byronic philosophy sees love as the ultimate, and only, essential truth and final resting place for one in this life. Love is the only force that still holds meaning. [...] The very foundations of love for the Byronic hero are based on failure and forgetting of what is possible. The Byronic hero in its purity can, by definition, never be redeemed by becoming a couple, he is interminably thrown back upon black despair; he is unremitting cast adrift into absence and dark night. In The Corsair, Conrad loses Medora because she pines away when she thinks he is dead. In The Giaour, Leila is murdered by her master because of her love for the Giaour, and the Giaour's life becomes one of vengeance against her murderer and then a tortured living in the past of his life. In Manfred, Astarte has died because of his unspecific sin. But finally the hero fails because this is the definition of the Byronic hero. He is the tormented melancholy failure who nears success and then fails and experiences eternal loss, the repetition of the impossibility of bliss. He retains his status as the outcast, the dangerous lover whose subjectivity is as large and as impoverished as the world. (52)

The Byronic hero has never had a chance of being either redeemed or fulfilled by his true love as his story often begins when it is already over, namely after the death of his love and he feels that his life and being have lost all meaning and purpose. Often he has been outlawed and robbed of his inheritance and status in society by envious relatives who have murdered his father. Thus, he turned him into a misanthrope who is isolated from society.

In addition, Thorslev states that "the Romantic heroes epitomized many of the most important aspects of Romanticism, and the Byronic hero shows the elements of every major type of Romantic hero" (4). Consequently, according to Thorslev, the Byronic hero is a combination of every major pre-existing type of hero. He represents characteristics of the "Child of Nature", "Hero of Sensibility", "Gothic Villain", "Faust" and "Cain" and "Prometheus". These Romantic heroes, whose genesis started in the Bible, and are then used by the likes of Shakespeare and then later Milton finally accumulate in the Romantic period in the Byronic hero. However, the question concerning the origin and development of Byron's creation continues to be debated.

Academic discussions are split into two groups. In one group, we find those who believe that Byron's heroes are direct descendants of the eighteenth-century Gothic Villain, and in the other group, we find those who position his origin

5 This concept of love is beautifully demonstrated in John Keats' Ode to an Grecian Urn. 
within the Bible, as does Thorslev. While I tend to be in agreement with the latter group, the first group does present some convincing arguments. Railo argues that Byron was mainly influenced by the works of Ann Radcliffe, seeing as her villain Schedoni in The Italian bears highly visible resemblance with Byron's protagonists in appearance. Both are described as having a high, white forehead, ebony curls, a dark piercing glance, a general beauty of countenance and a mysterious past (219). Nevertheless, he places the Byronic hero within an English tradition and claims that he is a purely English product, denying, among other things, the influence of Goethe and Schiller on Byron (219-224, 234). 6 Other critics argue that Byron's creation primarily stands in the tradition of Milton's Satan, who is a fallen angel; nevertheless a product of numerous influences, and his origins can be traced back to the bible. ${ }^{7}$

However, Byron himself gives the best description of his heroes in Lara:

There was in him a vital scorn of all:

As if the worst had fall'n which could befall

He stood a stranger in his breathing world,

An erring spirit from another hurled;

A thing of dark imaginings, that shaped

By choice the perils he by chance escaped;

But 'scaped in vain, for in their memory yet

His mind would half exult and half regret:

With more capacity for love than earth

Bestows on most of mortal mould and birth, His early dreams of good outstripped the truth,

And troubled manhood followed baffled youth;

With thought of years in phantom chase misspent,

And wasted powers for better purpose lent;

And fiery passions that had pour'd their wrath

In hurried desolation o'er his path,

And left the better feelings all at strife

In wild reflection o'er his stormy life;

But haughty still, and loth himself to blame,

He called on Nature's self to share the shame,

And charged all faults upon the fleshy form

She gave the clog the soul, and feast the worm;

'Till he at last confounded good and ill,

6 Eino Railo, 219-224, 234. However, Robert Woolf argues that Byron not only had read Goethe's Faust and was highly influenced by it, he also dedicated two of his plays to Goethe to demonstrate his admiration for him. Robert Woolf, Byron: A Dangerous Romantic? (Grasmere: Wordsworth Trust, 2003) 27.

7 For further discussion see: Andrew Elfbein, Peter Larson Thorslev, and Francis Wilson, (Introduction). 
And half mistook for fate the acts of will:

Too high for common selfishness, he could, At times resign his own or other's good,

But not in pity, not because he ought,

But in some strange perversity of thought,

That sways him onward with a secret pride

To do what few or none would do beside;

At this same impulse would in tempting time

Mislead his equally to crime;

So much he soared beyond, or sunk beneath,

And lodged by good or ill to separate

Himself from all who shared his mortal state ...

'Tis true, with other men their path he walked,

And like the rest in seeming did and talked,

Nor outraged Reason's rules by flaw nor start,

His madness was not of the head, but heart;

And rarely wandered in his speech, or drew

His thoughts so forth as to offend the view. (1. 313-348, 355-362)

The Byronic hero is here demonstrated as a mourning but simultaneously defiant man, whose characteristics as "fallen angel" are emphasised with a specific reference to Milton's Satan ("an erring spirit from another hurled", 1. 316). He has already been made cynical through occurrences outside his control and through the vice of man. He is haunted by a sense of crime, real or imagined.

In English Romantic Writers, Perkins characterises the concept of the Byronic hero as follows

The "Byronic Hero" [is] first portrayed in Cantos I and II of Childe Harold and thereafter developed variously in The Corsair, Lara, Childe Harold III and IV, Manfred and Cain. The figure had prototypes in the Gothic novels of the eighteenth century, in Chateaubriand's Réné and in the characters of Milton's Satan and of Napoleon as seen through Romantic eyes. The Byronic Hero continued to haunt nineteenth-century literature and philosophy. He is a man greater than others in emotion, capability, and suffering. Only among wild and vast forms of nature - the ocean, the precipices and glaciers of the Alps - can he find a counterpart for his own titanic passions. Driven by a demon within, he is fatal to himself and others, for no one can resist his hypnotic fascination and authority. He has committed a sin that itself expresses his superiority: lesser men could not even conceive a like transgression. Against his own suffering he brings to bear a superhuman pride and fortitude. Indeed, without the horror of his fate there could not 
be a splendour of self-assertion and self-mastery in which he experiences strange joy and triumph. (782)

Perkins expressly mentions both his fatality for others and his 'hypnotic fascination' which leads to the heroines' downfalls (in Jane's case to the necessity to flee from the Byronic power). However, like most critics, Perkins too excludes Byron's Don Juan from the concept of the Byronic hero. Thorslev argues that Don Juan seems strangely out of place when compared to Byron's other work because of its satiric style and uses this argument for leaving Don Juan out of his study (199). Railo, too, argues that Don Juan does not belong within the Byronic tradition, as the protagonist is ripped of his dark pose that is typical of the Byronic hero (241). Praz does not even mention him when he discusses the Byronic hero in his work. ${ }^{8}$ Although it might be assumed that the term "Byronic hero" refers to one specific character, this is not the case. Byron's protagonists differ immensely from each other, Elfenbein comments, "Don Juan pokes fun at the Byronic style which exhausted itself in Manfred" (40). What really lies behind the Byronic hero phenomenon and the reason why critics consider all of Byron's protagonist to be Byronic heroes, and why Don Juan also needs to be considered as a type of Byronic hero, is Lord Byron himself. The poet overshadows the characteristics of the Byronic heroes, and much of the Byronic conception is actually drawn from Byron himself and not from his heroes.

Various critics have commented on this phenomenon. Wilson, for example, supports this thesis by stating that Byron's personality was more influential than his poetry. According to Wilson, Byron not only portrayed the ultimate Romantic hero, but also hypnotised the whole of the Romantic generation and dominated the next (1). In addition, his life and scandals are still the subjects of various myths, and controversies about his life are still being discussed in a huge range of different biographies. Wilson estimates that more than 200 biographies have been written about Byron and every year new ones are published (1). This can be seen as a result of the strong connection between Byron's life and his prose. With the publication of Childe Harold's Pilgrimage in 1812, Byron became an immensely prominent figure. A downright frenzy about Byron and his work broke out which Annabell Milbank, later Lady Byron, summed up as Byromania to describe the con-

8 Furthermore, Torslev points out that Praz's focus on the Byronic hero is too narrow. He tries to demonstrate that the Byronic hero is a descendent from Milton's Satan and Ann Radcliff's villains but that he is also linked to the Marquis de Sade through his characteristics of the fatal and cruel lover. Additionally, he claims that Byron's creation is the ancestor of a long series of nineteenth-century vampires. But what he does not take into account is that Radcliffe's villains are evil through and through. They never feel redemption for their cruel deeds, where the Byronic hero is defined through his search for salvation. The connection to the Marquis de Sade is difficult to prove, too, as the Byronic hero may be a fatal lover but he is never cruel and is usually described as courteous and tender in his behavior towards women. As to the assumption concerning the vampire, there is only one reference in all of Byron's works in which one might assume that he is referring to a vampire (The Giaour l. 755). 
temporary mania for Byron and everything Byronic. His next poem The Corsair, which was published in 1814, sold 10,000 copies on its day of publication (Wilson 4). The poet Samuel Rogers commented that Byron's youth and rank combined with his "romantic wanderings in Greece" were the reasons why the world was "stark mad about Childe Harold" and its writer, for the identification of Byron with his aristocratic and world-weary hero was made straightaway (229). Nevertheless, the quality of the poetry is often left out when Byron and his success are discussed; contemporaries concentrated more on imitating his expression and style than on his poetic value. This attitude is still pursued even today; the Byronic hero as a concept and the Byronic Romantic are still being discussed, but his poetry is almost entirely left out of academic discussions. Thus, Wilson argues, the potency of his name is rather connected to a certain style and attitude than to the actual historic figure of Lord Byron (Introduction 9). In addition, Wilson reminds us that opposing concepts of the Byronic and Byron were and still are circulating:

Byronism has represented at the same time both solitary elegance and gross libertinism, physical indulgence and emaciation; the sharp dandy as well as the dishevelled wanderer are said to look "Byronic", and Byron was being erased officially at the same time as he was being recreated in the subculture of Byromania. (9)

Consequently, Byron became one with his protagonists and at the same time a figure of identification and desire in the public imagination; Byron became a star. The line between life and performance vanished, and they became the same thing. He even created a specific way to look for his self-portrayal as a Byronic hero', which numerous people tried to copy. Elfenbein adds that through his dominant Byronic character, Byron not only influenced and changed literary genres but also fashion, social manners, erotic experience, and gender roles of his time (8). He was a cultural phenomenon, one that had never existed before. He was portrayed and portrayed himself as Lord Byron as well as his protagonists, from the suffering Childe Harold to the satirical Don Juan. He played with the accusations of incestuous love for his half-sister Augusta Leigh and worked it into his poem Manfred, which only led to further speculation. Thus, as there was no distinction made between Byron and the Byronic hero, it is difficult to draw a line as to where the creator ends, and the creation begins.

Nowadays, Byronism is considered to be the first modern-style celebrity phenomenon. Nevertheless, the interest in the Byronic hero seems to have subsided in the 1960s. While during the first half of the twentieth century he was often referred to, and studies of the Byronic hero had appeared regularly, ${ }^{10}$ Thorslev

9 He would bend his head a bit and look out of the corners of his eyes to appear brooding and mysterious.

10 For discussions of the Byronic hero before the 1960s see among others: Mario Praz, The Hero in Eclipse in Victorian Fiction, (Oxford: Oxford University Press, 1959); Mario Praz, The Romantic Ag- 
wrote the last major study in 1962. Between the 1960s and 2006, Byron's creation seems to have been neglected or forgotten, and is only to be found in very few studies and articles. When mentioned in articles, critics only concentrate on specific facets of him, such as his function and appearance in works by George Eliot, Charles Dickens, Alexander Pushkin or Charlotte and Emily Brontë, but no booklength studies appeared. ${ }^{11}$ In 2006, Lutz's study The Dangerous Lover was published in which she revives the important and influential figure of the Byronic hero. Lutz notes that through the rise of feminism in the late 1960s, the literary persona of the dangerous lover, thus the Byronic hero, became an outcast within the critical literary world (12). Furthermore, the Byronic hero has always had a slightly negative connotation of marginalization, as it is thought that he appears mainly in romance novels, and that he mainly appeals to women. In any case, the romantic novel with a Byronic hero, the villain lover, at its centre, has still not been accepted as a distinct literary genre. Lutz, who argues that the dangerous lover plays a dominant role in today's romantic novels and cinema, also criticises this fact. Even if he appears mainly in female-coded genres, his existence needs to be recognised (ix). She also criticises the lack of a complete exploration of the dangerous-lover romance. Its history has not been thoroughly studied despite the fact that the villain lover, who became the Byronic hero, can be as far traced back as to the Elizabethan tragedy and is thus not only a figure that plays a part in subordinate literature but belongs to the literary canon (ix-x).

More importantly, Lutz's study is primarily a study about longing. It concentrates on the longing of the hero and scarcely considers the longing of his female counterpart, which still needs analysing. Lutz states that "Standing always under the sign of longing is the dangerous lover - the one whose eroticism lies in his dark past, his restless inquietude, his remorsefull and rebellious exile from comfortable everyday living." Furthermore, Lutz notes "When we long we encounter our own absence" (ix). According to this statement of Romantic ideas, the undefined longing of the Byronic hero is the reason why he goes out "into the anguished world in order to find, paradoxically, the self" (x). To find the "self" in an "other" and thus the wish and hope to be freed of the unbearable longing, to be redeemed through the love of this other, lies at the origin of the modern romance novel pattern. To find fulfilment and salvation in love is a privilege that has been denied to the original Byronic hero.

ony, (London: Oxford University Press, 1933); Eino Railo, The Haunted Castle: A Study of the Elements of English Romanticism (New York: Gordon Press, 1927); Jacques Barzun, "Byron and the Byronic", Atlantic Monthly (August, 1953); Charles Du Bois, Byron and the Need of Fatality, (London: Putnam, 1932).

11 See: William R. Harvey, "Charles Dickens and the Byronic Hero", Nineteenth-Century Fiction 24.3 (1969): 305-316; Sona Stephen Hoisington, "Eugene Onegin: An Inverted Byronic Poem", Comparative Literature, 27. 2 (1975), 136-152; Helen Brown, "The Influence of Byron on Emily Brontë" The Modern Language Review, 34. 3 (1939), 374-381. Sarah Wootton, "The Changing Faces of the Byronic Hero in Middlemarch and North and South, Romanticism 14.1 (2008), 25-35. 
The longing for something that cannot be achieved resembles Lacan's definition of "desire":

It is in the nature of desire to be radically torn. The very image of man brings in here a mediation which is always imaginary, always problematic, and which is therefore never completely fulfilled. It is maintained by a succession of momentary experiences, and this experience either alienates man from himself, or else ends in destruction, a negation of the object. (166)

Byron mainly places his protagonists in a situation where there is no longer hope, as the "other self", their true love, has already been lost. One of the first authors who actually placed the hero within reach of redemptive love is Charlotte Brontë, whose Mr Rochester could be saved by Jane Eyre.

Nevertheless, two questions come to mind: Why do critics believe that the Byronic hero is relegated to female-coded sub-genres only? Plus, why do they claim that this persona only appeals to female readers? As early as 1789 , Joanna Baillie argues in the "Introductionary Discourse" to her work Series of Plays on the Passions that as soon as the reader encounters someone who holds passionate feelings within him but tries to conceal them, a strong wish to reveal them overcomes us:

Let us understand, from observation or report, that any person harbours in his breast, concealed from the world's eye, some powerful rankling passion of what kind soever it may be, we will observe every word, every motion, every look, even the distant gait of such a man, with a constancy and attention bestowed upon no other. Nay, should we meet him unexpectedly on our way, a feeling will pass over our minds as though we found ourselves in the neighbourhood of some secret and fearful thing. (11)

Baillie does not differentiate between male and female reactions to these passions. Men as well as women are equally drawn to these secret feelings; they are both stimulated by them and an urge to discover them is awakened. Furthermore, the man who carries these strong passions suddenly holds an immense appeal for the people around him. Baillie continues:

If invisible, would we not follow him to his lonely haunts, into the midnight silence of his chamber? There is, perhaps, no employment which the human mind will with so much avidity pursue, as the discovery of concealed passion. (11)

Pinch comments on this passage "The very secretness of his passion not only incites people to discover it; it also makes him a strangely affecting being whose presence sends feelings to haunt us" (3).

Overall, neither Baillie nor Pinch differentiate between the wishes of men and women to discover the mystery behind those feelings. This leads to the question: Why has the need to discover the source of the guilt-ridden feelings of the By- 
ronic hero only been ascribed to women? McDayter addresses a problem that seems to lie at the root of the two previously asked questions: the division between art ("high- quality" literature) and mass culture (popular fiction). She argues that the denial of any desire in the process of academic literary criticism is the very reason why academics do not only ascribe the phenomenon of the Byronic hero but the phenomenon of Byromania itself to female hysteria (Byromania 9). Through the distinction between the male academic scholar, who analyses, and the female fan, who simply fantasises and is sometimes considered to be alarmingly enthusiastic, academic critics were able to dismiss the popularity of the Byronic hero as a female fancy. McDayter continues by stating that Byron and his poetry had as many male admirers as female, but the notion of fandom has been feminised and linked to hysteric women. Furthermore, critics in the nineteenth century tried to draw a line between critical readers, meaning men, and "hysterical readers of novels" meaning women. In order to ensure such a distinction, the whole realm of popular culture had to be ascribed to female fancies and was thus simultaneously marginalised (Byromania 15).

Knapp argues that the poet Samuel Taylor Coleridge tried very hard to "desynonymise" the perception of "enthusiasm" from "fanaticism", which was a hard task, as a differentiation was no longer made. Knapp writes that the overall opinion was that "just as enthusiasm must in a sense be quarantined, protected from social contagion that would degrade it to mere fanaticism, so poetry must be insulated from the modes of literality it both imitates and inspires" (42). However, Byron as a poet was not interested in differentiating between the enriching character of enthusiasm and proletarian fanaticism. McDayter supports Knapp's argument and adds, "On the contrary, Byron's literary fame seemed to act as a conduit for this disease, spreading his inflamed imagination to that of his readers, transforming his riotous fantasies into action" (18). This might be exactly one of the reasons for Byron's unprecedented success.

In addition, a scholar, as a critical analyst, should supposedly not only try to reveal the secret passions of the Byronic hero but also attempt to interpret them. This is apparently done by revealing the hidden sorrow, the "true" feeling of the Byronic hero could be discovered. However, McDayter states that trying to discover the truth behind the Other's passion and desire "is to conjure our own as the Other" (Byromania 13). Baillie suggests that the fascination the reader feels when he comes across such hidden passions is primarily attributed to the fact that such mysteries excite the reader's imagination to project his own truth into it. Thus, the reader draws on his own experiences, projects these into the secrets of the stranger, and only secondarily tries to discover the stranger's truth. Baillie deduces that this is an important procedure because "in examining others we know ourselves" (11). McDayter supports Baillie's argument. She states that by drawing on our own experiences to comprehend the mystery, already known passions are projected into it and thus the reader thinks he is able to understand the passions 
of the Other: "That which seduces us as a mystery is, in actuality, so very seductive because it is our desire we encounter as that of the Other" (Byromania 13). This conclusion is of great importance, as it challenges the former assumption that only women react to the Byronic hero because of some hysteric notions - it even challenges the assumption that only women are drawn to the mystery of the Byronic hero. Regardless, the Byron "fan", whether an enthusiastic reader or writer (who used Byron's literary persona) and the 'fan's' belief that there exists a hidden truth within the subject, is still looked down upon. For instance, Phyllis Grosskurth writes ironically:

The necessity to penetrate the hero's façade, to reach the sensitive heart that undeniably throbbed beneath the austere exterior became the determined purpose of every young woman who copied passages into her commonplace book. He might still be saved by a pure woman. (155)

She presents enthusiastic Byron readers as "screaming females" (159) who are naive enough to believe in the discovery of a hidden truth, while she herself declares in the introduction to her Byron biography to be a "seeker after truth" (xiii).

Where then is the line which separates the critics' and the fans' search for the truth? I suggest that the line is blurred, as already male contemporaries of Byron, learned and famous men, felt the attraction of his work and heroes and tried to identify the origin of his magnetism. In 1812, Jeffrey wrote that the secret of Byron "excited a kind of curiosity" as the "flashes of emotion and suppressed sensibility that occasionally burst through the gloom" would hit the reader like the force of the discovered truth $(2: 837)$. Walter Scott also stated that one could hardly resist the power of Byron's work "not only by many noble qualities, but by the interest of mysterious, undefined, and almost painful curiosity" that the reader feels while being confronted with the ferocity of his passions (176). Consequently, women writers who used the Byronic hero in their work were not hysterical, fanatic fans who wanted to copy his mysteriousness for "silly" romantic plots. On the contrary, female writers used the phenomenon of the Byronic hero to criticise standing gender roles and the threatening rise of the separate spheres ideology.

\subsection{The Separate Spheres Ideology}

The concept of separate spheres is based on a strict division of spheres into the domestic and the public, which developed in the late eighteenth century and dominated the whole of the nineteenth century. This artificially created concept coincides with the industrialisation and the rise of the middle class and had a huge impact on women's lives. The new invention of masculinity and femininity and the finding of new gender definitions played an important role in the confinement of the newly risen middle-class; it separated them from other classes. This separation between the sexes and their confinement to distinct spheres existed at every 
level of society and was one of the fundamental organizing characteristics of the middle-class society in the late eighteenth and early nineteenth century. ${ }^{12}$

Every part of a woman's life was affected by this ideology; she was supposed to stay at home and was not allowed to be involved in political discussion. Women were seen as "covert" humans, meaning they were perceived as "relative creatures" who were financially, emotionally, and intellectually dependent on their male relatives (Gleadle 51). Vickery writes that women have been linked to the domestic sphere since the time of Aristotle, but the term "separate spheres" emerged only recently with an entirely new character and was essential to constitute new limitations and oppression for women (383). The role of the 'Angel in the House' was ascribed to women and they were expected to live according to this image. This meant that women should be passive, sacrificing, loving, caring, silent, obedient, and submissive. ${ }^{13}$ Historians have suggested that the female education of the time was only focused on tasks that were important for domestic life. A woman's primary role was, as Morgan points out, the raising of children, as it was the mother who was supposed to transmit the current values to her offspring. A mother's influence on her children was seen as enormously important, in particular her influence on boys, as they were to become the citizens of the future. It was hoped that a strong moral influence at home would produce men with moral courage and strength (Morgan 192). Furthermore, it was thought that this "motherly" influence could eventually improve the whole of society, and it was therefore important that they kept up their moral mission. New restrictions came along through this idealization of women; they were bound to stay at home and not involve themselves in politics, because moving into the 'public sphere' could be a threat to their task and could therefore have damaging effects on the moral standards of a whole nation. There was a concern that if a woman was to involve herself in politics, she might not have enough time to concentrate on her actual duty, namely providing her husband with a safe haven from the public sphere and supervising the education of her children (Morgan 199-201). Sarah Ellis, a contemporary writer of conduct books and a self-appointed advocate of the separate spheres ideology, even declared that if a woman engages herself in the public

12 See Leonore Davidoff and Cathrine Hall, Family Fortunes: Men and Women of the Middle Class 17801850 (London: Routledge, 1987) ch. 3 for a rich discussion of domestic ideology.

13 The phrase the "Angel in the House", which aptly characterises the new role of women, was introduced in a poem by Coventry Patmore in 1854 and was next to Tennyson's "Idylls of the King" a best-selling poems at that time.. Patmore wrote the poem for his wife and the plot is rather simple, it is about the courtship and marriage of a young couple. The poem is central to the concept of the separate spheres ideology in light of how it idealises womanhood and dictates the virtues a woman should have. She should be sacrificing, loving, caring, silent, comforting, passive and should provide her husband with a domestic haven away from the severe world of business and politics. Virginia Woolf was the first one who used the term "Angel in the House" critically and turned it into an item of feminist criticism (see her essay "Professions for Women" [1929]). 
sphere (paid work, politics, etc.) she "ceases to be a lady" (qtd. in Davidoff and Hall 3). In other words, the separate spheres concept imposed bondage on women that permeated every aspect of their being. Rights and independence were denied to them, desires and passions had to be suppressed and the justification of there existence was connected entirely to their roles as mothers and wives. ${ }^{14}$

Until recently, feminism has represented Victorian sexuality in terms of opposites: Angel and fallen woman. This conception summarised the discourse of sexuality in the Victorian age, and it continues to direct the modern view of the correlation between women and sexuality in the nineteenth century. Reynolds and Humble note that:

(T)he sense of being torn between two incompatible positions typifies much twentieth century feminist criticism ... Stimulated in particular by the work of Michel Foucault, feminists have made many fruitful readings of a wide range of Victorian images which explore the relationship between femininity and sexuality. Time and again the contradictory nature of this relationship has been brought to the fore. The complexity and prolificacy of the discourses surrounding female sexuality amply support Foucault's thesis that traditional images of Victorian Britain as refusing to acknowledge sexuality have been mistaken. (1-2)

Reynolds and Humble proceed by arguing that the public discourses concerning sexuality, which state that a woman is either the angel in the house, submissive and sexually passive, or a "sexually charged and demonic mad-woman-in-theattic" (2) cannot be seen as private reality. They judge the common understanding of Victorian sexuality as a dyadic model as out-dated, since "common sense suggests that the Victorians' angelic feminine ideal is entirely suspect" (3). They allude to the fact that for women the Victorian was not a static epoch but ever changing. It started with the invention of the separate spheres notion and the creation of the angel of the house and ended with the fragile females in "bloomers, in offices, in higher education, and driving motorcars" (4-5). Still, the word "Victorian" is still associated with "prudery, repression, hypocrisy, smug confidence, and uncompromising patriarchy" (5).

Nevertheless, a tendency to set up boundaries and establish certainties through classification and categorising was commonplace during the Victorian period. This tendency is particularly evident in its application to sexuality, which led to an oppressive ideology, a division of female and male experiences ${ }^{15}$ and the categorisation of women as "pure" or "impure". However, in the approach of female sexuality within the Victorian period, tensions and contradictions were seen that easily

14 It must be mentioned that contemporary discussions result in the realization that the reality differed immensely from the idea of the separate spheres. The Angel in the House was not to be found, the concept, however, brought along restrictive conventions for women.

15 For a detailed presentation of the public sphere read Jürgen Habermas 1989. 
challenge the idea of a dyadic model. ${ }^{16}$ While it was argued that men's sexual urges were regrettable but not uncommon, women were seen as unnatural, mad, and abnormal when experiencing sexual desire (Reynolds and Humble 6-7). Within this ambivalent attitude towards sexuality, the symbolic importance of Byron and his hero becomes evident. Moglen explains that:

The ideal by which Byron attempted to define his life expressed not only personal but collective longings of psychic and social liberation. But the reality of his circumstances betrayed the potency of the forces which obstructed freedom and thwarted realization. In his own relationship with women, and in the relationships which he created for his heroes, the poet expressed the complex destructive and self-destructive attitude which refine romantic. (31)

\subsection{Julia Kristeva: The Symbolic and the Semiotic}

Kristeva's theory of the "semiotic" and the "symbolic" demonstrates that such a denial of the self and an absolute devotedness to a social construct can never be achieved. According to Kristeva "every social practice ... is articulated like a language" (author's emphasis) ("The System and the Speaking Subject" 25). Furthermore, she states:

Every social practice, as well as being the object of external (economic, political, etc.) determinates, is also determined by a set of signifying rules, by virtue of the fact that there is present an order of language; that this language has a double articulation (signifier/signified); that this duality stands in an arbitrary relation to the referent; and that all social functioning is marked by the split between referent and symbolic and by the shift from the signified to signifier coexists with it.

One may say, then, that what semiotics had discovered is the fact that there is a general social law, that this law is the symbolic dimension which is given in language and that every social practice offers a specific expression of that law. ("The System" 25)

Thus, Kristeva's interpretation of "symbolic" can be seen in the style of Lacan's technical term "Law of the Father" which belongs to his definition of the "Symbolic Order". Lacan describes it as the moment when s/he must abide to the symbol of the phallus as the embodiment of the Law of Fathers and accordingly

16 Reynolds and Humble suggest that, among others, the vast number of prostitutes, Victorian women's clothing and the rise of the "New Women" are all evidences of the overtly challenge of the dyadic model. Furthermore, representations in novels or paintings, of Victorian heroines show them as sexually powerful beings. In the course of their study, Reynolds and Humble identify various efforts to recover resume and recover female, middle-class sexuality. 
must accept the thereby accruing castration. The recognition of this castration is required in order to enter into society as an established individual; nevertheless, it simultaneously demonstrates that this society is a patriarchal and oppressive one. As Kristeva puts it:

[...] the symbolic - and therefore syntax and all linguistic categories - is a social effect of the relation to the other, established through the objective constraints of biological (including sexual) differences and concrete, historical family structure ("Revolution in Poetic Language" 97).

Thus, the symbolic is associated with authority, order, repression, and control, with family and normalcy. Furthermore, it is seen in connection with the "conscious", meaning an "orderly surface realm of strict distinctions and laid-down structures through which language works" (Barry 123-124). The symbolic function is the place of "unitary" law for the subject, the place for renouncing pleasures (drives) that come up against social censorship. It is also the place where the closed sign is established (the linear division of the sign) through the absence of the rejected or repressed object (possible signifiers).

By contrast, the semiotic aspect of language is a violent force disrupting the symbolic order. Its social practice is connected with the maternal rather than the paternal. Kristeva argues that the semiotic does not belong in the same category as logic and order, she describes it with the terms displacement, repulsion, rejection slippage and condensation ("Revolution" 97). It continuously endangers the stability of the symbolic categories, such as the law and images that sustain and support culture. She does not only link it with the feminine, in particular to the mother's body ("Revolution" 95), but also to the "poetic language", which she describes as "the semiotic disposition will be the various deviations from the grammatical rules of the language" ("The System" 28).

As Barry states, in summarizing Kristeva's idea of the semiotic: The semiotic is the "unconscious" of a text emerging into and disrupting the conscious or the surface of meaning. "[The semiotic is] a disruptive incursion into rational, previously stable structures [as] they are shown in dreams, poetry, modernist and experimental writing" (Barry 124). The semiotic is thus seen as everything that deflects from the symbolic. However, the symbolic and the semiotic cannot be considered as two different kinds of language, only as two different aspects of it, which are always connected in every given sentence.

In the following, I will draw on Kristeva's discourse of the semiotic and symbolic to present and discuss the imposed restrictions on women in nineteenthcentury Britain. Lady Caroline Lamb's Glenarvon, Charlotte Brontë's Jane Eyre and Ellen Wood's East Lynne, appear particularly suitable for the discussion. First, because they were written by women who had to live within the limits of the boundaries that were imposed on them because of their gender. Secondly, because as the novels were written in different decades of the nineteenth century, different 
interpretations of the Byronic hero are given, by the novelist. All three female novelists demonstrate considered and typical interpretations, through different responses to this literary persona, depending on the decade they wrote in and by which they were influenced. They thus offer several levels of imitation, revision, and rejection of the Byronic hero in their novels; still, they all use him to excite female emotions. Furthermore, the female character's struggle to comply only with the symbolic order will be depicted though Kristeva argues that such a compliance is not achievable. It will also be shown how the authoresses present the symbolic and semiotic in their work. Although it has been demonstrated that the Byronic hero fascinates men as well as women, the focus lies on how the literary persona excites, triggers, and catalyse repressed female desires. These tend to be enforced to such an extent that it results in an explosion of female sexual desire, which ends most of the time in disaster and eventually in death. Thus, female novelists use the Byronic hero to criticize constricting gender roles.

\section{Lady Caroline Lamb's Glenarvon}

Everybody wishes to run down and suppress the vital spark of genius I have, and truth, it is but small (about what one sees a maid gets by excessive beating on a tinder-box). I am not vain, believe me, nor selfish, nor in love with my authorship; but I am independent, as far as mite and bit of dust can be (qtd. in Douglass, Introduction xxviii).

From the moment Glenarvon was published in 1816, it has been reduced to an assumed biographical account of the scandalous affair between Lady Caroline Lamb and Lord Byron. At the time of the novel's release, Byron was not only at the height of his popularity, but had also only recently agreed to a separation from his wife Annabella Milbanke, a cousin of Lamb's. Two weeks before the publication, he had left England for a self-chosen exile, as the scandalous rumours about a sexual relationship with his half sister Augusta Leigh became more and more oppressive. Additionally, the very public affair of Lamb and Byron had stirred a craving for more savoury details. Butler notes:

Enormous curiosity about Byron's life already existed, but no biographies had appeared. Understandably, the public eagerly scanned Glenarvon for clues that would reveal the mysterious author of Childe Harold I and II and the Oriental Tales. Even Goethe, though the novel bored him dreadfully ... read it from cover to cover under the impression that he was gleaning reliable information about Byron's private life. (37)

Therefore, after Lamb's novel was published, it not only became an immediate success but was also eagerly scanned for clues that would reveal Byron's true identity. Furthermore, Glenarvon has been read as a "compulsive act of confession" 
(Douglass, Introduction xxix). Olney suggests that Lamb intended the novel "primarily as an act of contrition and humility; a public confession of $\sin$ " (275), although he is not specific as to which sins she confesses. Clubbe states that the novel "forced itself out of her: she had to write it as much as Byron had to write his confessional poems" (205). ${ }^{17}$

Glenarvon was first published on the 9th of May 1816. In June, the public had already demanded a second edition, a third edition was published in the same year and a fourth in 1817. As already mentioned Glenarvon was considered a kiss-andtell story of Lamb's and Byron's liaison, a roman à clef. ${ }^{18}$ The novel is a curious mix of different genres, including, the political and historical novel, novel of manners, literary-social satire, and Gothic romance. The plot itself is generally considered to be confused, over-complex, and absurd (Franklin xiv). Douglass even describes it as an "angst-filled tryst and overwrought exclamation of love, pain and selfrecrimination" that is "tiresome in its repetition" (Introduction xxxix). It tells the story of the married Calantha, ${ }^{19}$ a virtuous girl, who falls desperately in love with the revolutionary Lord Glenarvon. Calantha is generally viewed to reveal more about Lamb herself, sexually and biographically. Set against the backdrop of the Irish revolution in 1798, bit by bit the plot evolves around Glenarvon, who in his multiple disguises as the child-murdering Viviani and the fatalistic Glenarvon, seduces almost every female character. He betrays them and leaves them to madness and doom, just as he abandons his revolutionary followers who see him as their leader in the fight for independence. Lamb not only depicts Glenarvon's mysterious hypnotic charm but also demonstrates the resulting dilemma for women when they give into their desires.

In the following, the focus not only lies on Lamb's novel but also on her life, as she is the author who had a passionate affair with Byron and consequently with the Byronic hero. Even more, she was the first writer who used the persona of the Byronic hero in a novel. She thus started a new literary trend that is even nowa-

17 The notion of female writing forcing itself out is discussed in Hélène Cixous' "The Laugh of the Medusa". She argues with the imagery of a volcano when discussing female writing in general. She states that "a female text cannot fail to be more than subversive. It is volcanic; as it is written it brings about an upheaval of the old property crust, carrier of masculine investments; there is no other way". Cixous sees the function of the final eruption to "smash everything, to shatter the framework of institutions, to blow up the law, to break up with the "truth" with laughter" (888).

18 This is justified, to some extent, since Lamb incorporated letters of Byron into the novel that some friends of his recognized as such. As a result, it was taken as a truthful account of their affair (Duncan Wu 143).

19 The name "Calantha" originates from John Ford's The Broken Heart (1633). Evidence for this assumption can be found in Glenarvon itself when Lady Augusta says: "At this moment you put me vastly in mind of it [Ford's tragedy]. You look most woefully. Come, tell me truly, is not your heart in torture? And, like your namesake Calantha, while lightly dancing the gayest in the ring, has not the shaft already been struck, and shall you not die ere you attain the goal?" (155). The connection with Ford's work alludes to Calantha's tragic end. 
days extremely popular and successful. In addition, Lamb was the first to use him to criticise unequal power relations between men and women. Because of her affair, she can give a first-hand account of the fatality of falling in love with a Byronic hero and of his "hypnotic fascination" of which Perkins writes. Furthermore, she had to endure the criticism and condemnation of society because she was not willing to comply with an oppressive patriarchal system. A demonstration of the criticism of this system in Glenarvon that oppresses women in several ways (e.g. through an inadequate female education) and forces them to repress their natural sexual desires will be given. Lamb uses the Byronic hero in the shape of Glenarvon as a trigger of female desire, who arouses this desire to such an extent that it can neither be repressed nor ignored.

\subsection{Lady Caroline Lamb: A Love-Mad Woman}

Lady Caroline went down in history as the woman whose obsessive love for Byron drove her insane. Deeds like the sending of her pubic hair, after Byron had ended their affair, only seem to add to this assumption. Her pubic hair, which was enclosed in a small locket, was delivered with the following letter:

I asked you not to send blood but Yet do - because if it means love I like to have it. I cut the hair too close \& bled much more than you need - do not you the same \& pray put not scizzors points near where quei capelli grow - sooner take it from the arm or wrist - pray be careful - \& Byron - tell me why a few conversations with the Queen Mothers ${ }^{20}$ always change you. ... When you left me I must one night be in your arms - \& now not even see you but in presence of a witness - oh I could scold - ... I will kneel \& be torn from your feet before I will give you up - or sooner be parted with you. (qtd. in Tuite 59)

The note clearly shows that she simply refused to accept the end of their affair and continued to pursue him.

Her scandalous behaviour and her very public pursuit of Byron led to the presumption that she must be mad. Byron himself helped to create the image of her as an adulterer and persecutor; he openly mocked her pursuit of him and presented her love letters as amusement to Whig society. Wu notes that his "disparaging assessment has led some to regard her as little more than one of the more bizarre features of his love-life" (140). Byron wrote to John Moore in 1816 "It seems to me that if the authoress had written the truth, and nothing but the truth the whole truth - the romance would not only have been more romantic, but more

20 Lamb refers here to Lady Melbourne, Caroline's mother-in-law, and Lady Oxford, who both had amorous liaisons with Byron. 
entertaining". Concerning his likeness in Glenarvon he comments that it was a "bad picture" as he had "sat not long enough" for it (qtd. in Clubbe 214).

In addition, Lamb is known for coining the famous formula describing Byron as "mad, bad and dangerous to know". However, this was not her first impression of Byron but a conclusion after years of reflection. Although less known but yet still adding to her reputation of an insane woman, were Byron's comments, calling her "mad and malignant", and a "monster" who "cannot be in her senses" (Douglass, "Madness of Writing" 53). Additionally, he wrote in a letter to Lady Byron "[H]er whole disposition is a moral phenomenon (if she be not mad) it is not feminine - she has no real affection ... but everything seems perverted in her she is unlike every body I know - \& not even like herself for a week altogether" (qtd. in Douglass "Madness of Writing" 53). In other words, Byron himself helped to spread the rumour of her supposed insanity. Accordingly, Lamb's formula gets under this aspect a whole new quality.

Wilson reminds us that Lamb is still remembered as a woman who could not differentiate between fiction and reality. Her name was and is a synonym for the melodramatic to this day; it was even used by contemporaries, including Byron, as an adjective for "self-indulgent emotionalism" ("An Exaggerated Woman" 195). In addition, he points out that Caroline's behaviour applied to the "myth of desiring women" which depicts them as being "damaged and damaging", as "unnatural, theatrical, deceptive, duplicitous, witch-like" and "sexually excessive" ("Exaggerated" 199). All of those characteristics were applied to Lamb, and thus her work has merely been viewed with the focus on the sexual, rather than the political, on the scandalous affair, rather than on the critic within. McDayter states that Chew, a well-established Byron critic, evaluated Glenarvon as "the product [of Lamb's] hysteria" and therefore, McDayter argues "can be [according to Chew] summarily dismissed, aesthetically, and politically, in a single satisfying stroke. It is about sex, not a "legitimate" literary subject such as politics" ("Hysterically Speaking" 155). Chew is not alone with his poor opinion of Lamb's work. Cecil regards it as the "merely outpouring of a diseased sexuality" (qtd. in Kelsall 138) and further as "a deplorable production, an incoherent cross between a realistic novel of fashionable life and a fantastic tale of terror, made preposterous by every absurd device" (qtd. in Graham 95). Up until recently, numerous critics agreed that the only merits of the novel were the powerful depiction of the heroine Calantha and her affair with Glenarvon because of their biographical aspects. ${ }^{21}$

Tuite discusses the decade long double standard of the handling of the affair; she states that the relationship between Byron and Lamb confirmed his "seductive

21 Henry Blyth. Caro: The Fatal Passion. New York: Haper Collins, 1972. - Mabell, Countess of Airlie. In Whig Society 1775-1818, Compiled from the Hitherto Unpublished Correspondence of Elizabeth, Viscountess Melbourne, and Emily Lamb, Countess. Cambridge: Scholar Publishing, 2010. - Elizabeth Jenkins. Lady Caroline Lamb. London: Sphere, 1972. George Paston and Peter Quennell. "To Lord Byron": Feminine Profiles based upon unpublished letters 1807-1824. London: Murray, 1939. 
fatality" and her "banality" (61). Born Lady Caroline Ponsonby, her mother being Lady Bessorough and her aunt Georgiana, Duchess of Devonshire, Lamb grew up within one of the most powerful and influential circles of Regency England. Her aunt and mother were one of the few politically significant women of the time. Marie Antoinette, as well as the Prince of Wales belonged to her family's acquaintances and her future husband, William Lamb, would be Victoria's first Prime Minister. Accordingly, she belonged to England's social elite, which even enforced the public's interest in her life and scandals.

Extra-marital affairs were not uncommon in Regency England but they were only tolerated as long as they were kept private. With the publication of Glenarvon, Lamb not only violated this rule but also drew a satirical and critical picture of Regency's upper circles, only thinly disguising some of its most powerful members. This resulted in Lamb's social death. She became a social exile, mirroring Byron's self-exposed exile from England to the continent. Nevertheless, Tuite argues that their exiles varied immensely in their result as " $t$ t] he narrative and plot of exile is significant here because there is a sense in which the crossing over, as it were, from social death into literary fame or posterity, enacts a strategy of immortality that translates exile or ruin into redemption" (79). Accordingly, the aftermath of their exile differed because of their gender difference. Where Byron's short life on the continent lead to a change of his reputation from being a scandalous outlaw to having heroic fame, Lamb had to endure continued public humiliation that included a public diagnosis of insanity, and she was left no hope of posthumous redemption.

The significance of these background details lies in the critique of patriarchy and the symbolic in Glenarvon itself. Lamb's's life and reputation are examples of the consequences "desiring women" had to endure. She is one of these women who choose to give in to their passions: to object to Kristeva's repressive symbolic and indulge in the semiotic. The Byronic hero, as Lamb uses him in Glenarvon, has a very special relevance as she not only lived during the same era as Byron, but was also influenced by the same concepts and ideals as he was. ${ }^{22}$ Accordingly, Lamb's Glenarvon is closer to the original Byronic hero than those of her follower's are. In addition, she also knew the real Byron, hence she knew from firsthand experience how seductive and fascinating the "Byronic hero" was. She experienced how easily one could succumb to his charm, how short-lived his love was and how severely one was punished by society for surrendering to him. Having recognised society's double standard on sexual indiscretion, she protests it in Glenarvon:

22 On of those being the romantic longing, a longing that can and even should never be fulfilled. The fulfillment of this longing necessarily ends in tragedy and disaster as depicted in Glenarvon, as the "longing" itself is the essential expression of Romanticism. 
That which causes the tragic end of a woman's life [i.e. her reputation and social life], is often but a moment of amusement and folly in the history of a man. Women, like toys, are sought after, and trifled with, and then thrown by with every varying caprice. Another, and another still succeed; but to each thus cast away, the pang has been beyond thought, the stain indelible, and wound mortal. (278)

Neither contemporaries nor critics could appreciate Glenarvon for its critique on existing gender roles but the focus lay, as already mentioned, on the assumed insight into Byronism and Whig society. Even political events such as the Irish uprising in 1798 were not acknowledged. Critics like Solderholm, regardless of their recognition of her supposed hysteria and insanity as calumny, still do not recognise Lamb's work on its own account, but mainly in relation to Byron. Solderholm not only denies her any kind of originality, but also argues that her motivation "can be more generously understood as a spectral pursuit of her own kind of proto-Byronic, erotic-notoriety: an imitation of her ideal man" (26). Other critics follow in his steps and see Lamb's work as an imitation of Byron, as an attempt to create her own Byronic character in order to be close to him. ${ }^{23}$ Furthermore, critics who write favourably of her work and defend it against its more vehement opponents, only recognise the merits of her work in the supposed biographical and social depiction of Byron and Whig society and its confessional character. ${ }^{24}$

However, more recent critics do not agree that revenge or confessional outpouring were the motives behind Lamb's writing of Glenarvon and have recognised its critique of restricting conventions for women and hypocritical values in society. ${ }^{25}$ Douglass states that Lamb had mixed motives in writing the novel. Although agreeing that striking back at Byron and those who had humiliated her might have been one of them, he believes her main motive was that she wanted to "reveal wrapped values of society that knowingly continued to abide behaviour that was more criminal than her own" (Introduction xxx). Lamb criticises this condition by pointing to the corruption of Calantha's innocence by society, as the following paragraph shows:

Her reason by degree became convinced by the arguments which she continually heard; and all that was spoken at random, she treasured up as truth: even whilst vehemently contending and disputing in defence of her favour-

23 Among others, Barbara Judson discusses how similarities of Byron's and Lamb's work have recently been discovered and discussed but only to demonstrate the" inferiority and derivative nature of Lamb's work - her attempt to "play Byron," to appropriate his myth of personal authority for herself' (151).

24 John Clubbe suggests that Glenarvon works only when read as a satire (208) and mainly fails as a novel but could be considered as a self-analytic study oft the writer concerning her relationships with Byron, her husband William Lamb and Regency society (210).

25 To this critics belong, among others, Gishlane McDayter, Frances Wilson, Barbara Judson, Ducan Wu and Paul Douglass. 
ite tenets, she became of another opinion. So dangerous is a little knowledge - so unstable is violence. Her soul's immortal hopes seemed to be shaken by the unguarded jests of the profane ... she read till she confounded truth and falsehood, nor knew any longer what to believe: she heard folly censured till she took it to be criminal; but crime she saw tolerated if well concealed. (60)

The paragraph not only criticises society's hypocrisy but also mentions a more farreaching problem: the dangers of insufficient female education.

\subsection{Female Education; or the Fine Art of Hysteria}

Lamb is not the only woman whose personal and scandalous life has influenced the perception of her work, thus she was not the first (and not the last) to have her writing dismissed as emotional scribble. Mary Wollstonecraft, one of the most influential writers of the Romantic period commenting on the status of women, had to endure the same procedure. As Craciun comments, "Wollstonecraft's violent relationship with Imlay, and her resulting two suicide attempts in 1795 when he had moved in with another woman, dominated the reception of her work throughout the nineteenth century" (10). Lamb was not only familiar with Wollstonecraft's work, but also admired it tremendously. Glenarvon was highly influenced by Wollstonecraft's agenda which makes it particularly interesting for contemporary criticism, as feminists have discussed that "gender carries an ideology as distinctive as the political attachments highlighted by new historians" (Wu 145).

In a time in which Rousseau's Emile, or On Education (1762), an educational treatise, was immensely significant, restrictions on women because of their subordinate gender increased. Rousseau claims that men and women are fundamentally different, physically and intellectually. Furthermore, he suggests:

[T] he whole education of women ought to relate to men. To please men, to be useful to them, to make herself loved and honored by them, to raise them when young, to care for them when grown, to counsel them, to console them, to make their lives agreeable and sweet - these are the duties of women at all times, and they ought to be taught from childhood. (166)

It is obvious that Rousseau not only demands women to merely act within the sphere of what Kristeva calls the symbolic, he also strongly advises men to let their women act only within this sphere. Otherwise, severe consequences were the result, thus, he warns the male population that if women should be allowed to give in to their sexual desires:

(M)en would be tyrannized by women. For, given the ease with which women arouse men's senses and reawakening the depths of their hearts the remains of ardors which are almost extinguished, men would finally be their 
victims and would see themselves dragged to death without ever being able to defend themselves. (169)

As a result, in order to prevent female tyranny and domination, men should keep their female relatives in check and women's education should concentrate in every respect on pleasing men, and simultaneously on the repression of their own wishes.

Lamb is well aware of this agenda and criticises it vehemently in Glenarvon, demonstrating the dangers the world holds for an uneducated, and therefore easily impressed mind, as well as the effect of repressed desire on women. She agrees with the criticism Wollstonecraft expresses of such an education and sees the same dangers as Wollstonecraft did:

The education of women has, of late, more attended to than formerly; yet they are still reckoned a frivolous sex, and ridiculed or pitied by the writers who endeavour by satire or instruction to improve them. It is acknowledged that they spend many of the first years of their lives in acquiring a smattering of accomplishments; meanwhile strength of body and mind are sacrificed to libertine notions of beauty, to the desire of establishing themselves, - the only way women can rise in the world, - by marriage. And this desire making mere animals of them, when they marry they act as such children may be expected to act: - they dress; they paint, and nickname God's creatures. - Surely these weak beings are only fit for a seraglio! - Can they be expected to govern a family with judgment, to take care of the poor babes whom they bring into the world? (qtd. in Craciun 111)

Lamb adapted Wollstonecraft's critique on female education and incorporated it into Glenarvon. Accordingly, female education is often commented on in her work. Mrs Seymour, Calantha's aunt, has raised her daughters in the "proper" way and has diminished every spark of passion and desire in them. Lamb obviously attacks this manner of education through Lady Margaret, Calantha's aunt:

By these means, Sophia and Frances were already highly accomplished; their manners were formed; their opinions fixed; and any contradiction of those opinions, instead of raising doubt, or urging to inquiry, only excited in their minds astonishment at the hardihood and contempt for the folly which thus opposed itself to the final determination of the majority, and ventured to disturb the settled empire and hereditary right of their sentiments and manners ... "But, in your girls and in most of those whom we meet, how narrow are the views, how little the motives, by which they are impelled. Even granting that they act rightly, - that by blind following, where others lead, they pursue the safest course, is there any thing noble, any thing superior in the character from which such action spring?" (28-29) 
Lady Margaret criticises this conformity and inability to react to new situations, to have no opinions of your own and to bend unquestionably to society's standards. She also refers to Sophia's and Frances' lack of desire: “These are your pupils ... these paragons of propriety - these sober minded automatons ... I only wish I could shake off a little of that cold formality which petrifies me" (28). When she describes the upbringing intended for Calantha, it seems to be in the manner of Rousseau: "Now see how differently my Calantha shall appear when I have opened her mind, and formed her according to my system of education - the system which nature dictates and every feeling of the heart willingly accesses to" (28). Probably influenced by Wollstonecraft, Lamb condemns women like Lady Dartford and Sophia, who submit to the symbolic, to those "paragons of propriety" whose interests lie only in dresses and jewels. Based on Calantha's case, Lamb tries to demonstrate the dangers of an education that focuses on superficiality and not reason. She attempts to expand the world of female experiences and to extend it into the world of politics, poetry and passion and demands an improvement of the options for women.

The topic of female education, or rather the inadequacy of female education is of the utmost importance here, seeing as for Lamb the repression of desire and passion starts in the education of girls. They are not seen as reasonable beings, and reason is not exercised, they are not taught how to control their desires, only to deny them. The fate of the heroines in Glenarvon are an open attack on Rousseau's philosophy concerning female education they demonstrate the ridiculousness and the outspoken danger of an education that focuses on innocence only. Consequently, when suddenly confronted with the public sphere or "outside world" they have no guidance. McDayter points out that while these women are still girls they only appear submissive, controlled, and restrained but as soon as they mingle with the "outside" world and are confronted with passion, desire, and sexual lust "they reveal an ephemeral nature of this passivity". She continues to say that "under the seemingly calm surface is a positive torrent of repressed and denied desires only barely restrained by the enforcement of social restrictions and cultural laws" ("Hysterically Speaking" 164-165).

We are told that this is the case with Calantha: "Her feelings indeed swelled with a tide too powerful for the unequal resistance of her understanding: - her motives appeared the very best, but the action which resulted from them were absurd and exaggerated" (29). Embodying the Rousseauian idea of feminine fragility and charm, Calantha, when still a child, was spoiled by all: "[T]he wildest wishes her fancy could invent, were heard with the outmost scrupulous attention" (29). She never learned to control the always-changing "impulses of her feelings" and thus grew up to become "more than usually ignorant, backward and uninstructed" (30). McDayter comments that although Calantha's depiction as a Rousseauian heroine does not follow exactly his conventional education, she still has to live with all its restrictions and repressions, even though she is aware of how weak 
and unprepared her education has made her ("Hysterically Speaking"164). This proves Calantha's self-assessment:

"I am not like those I see: - my education, my habits, my feelings are different; I am like one uncivilized and savage; and if you place me in society, you will have to blush every hour for the faults I shall involuntarily commit.

Besides this objection, my temper - I am more violent - ..." (49)

Again, Lamb's source for this explication of education comes directly from Wollstonecraft's $A$ Vindication of the Rights of Woman. Both women have penetrated and understood the dilemma such an education beholds for women. The idea of a proper lady was a fixed concept; every female aberration that challenged this concept was scrupulously judged by society. A desiring woman violated the idea of "natural femininity", and the belief that masculinity and femininity were biological parameters of identity. Concerning their sexual identities, as Wilson states, they had two options to choose from, to be the "passive object or active subject of desire". Nevertheless, Wilson proceeds "the expression of desire was traditionally associated with the masculine and the sexual power which this position ideally represents ... any expression on the woman's part is seen as kind of theft" ("Exaggerated Woman" 204). Calantha, as Lamb herself, thus becomes "unnatural" and is judged as a disfiguration of femininity. Desiring and longing women become, in their expression of their passion for men, "unsexed" beings. Women are only expected to fulfil men's desires within the symbolic.

Contrarily, they are also raised to be sensual beings. They are explicitly taught how to use their bodily facilities to arouse men, and how to neglect their minds. As Wollstonecraft puts it:

Taught from their infancy that beauty is a woman's sceptre, the mind shapes itself to the body, and roaming around its gilt cage, only seeks to adore its prison .... . Women, confined ... having their thoughts constantly directed to the most insignificant part of themselves, seldom extended their thoughts beyond the triumph of the hour. But were their understandings once more emancipated from the slavery to which the pride and sensuality of man and their short-sighted desire, like that of a dominion in tyrants, of present sway, has subjected them, we should probably read of their weakness with surprise. (qtd. in Craciun 128)

They are intentionally kept ignorant of reason and have only their bodies to turn to whose desires they are not allowed to articulate, as it is considered as "unfeminine" and "unnatural". However, a woman's way to express her desire is over her body, as she has been taught since childhood how to use it to seduce men and eventually catch a husband.

Accordingly, using the example of Calantha and her fall, Lamb demonstrates the dangers of being forced to comply to the symbolic solely. Without being al- 
lowed to connect with the semiotic, long repressed desires break free in a destructive explosion. As men allow women to consider themselves as their queens, they put them on a pedestal of beauty and sensuality. Nevertheless, this role is shortlived, since men have the power to put them back in their place as subordinates whenever they wish to. Accordingly, women were trapped; no matter what they decided to do, they were judged for it. Depicting Calantha as a girl educated after Rousseau's conception of female education, her fall lies ahead. Lamb's feminist approach, to criticise the repressive restrictions for women in a patriarchal system, concentrates, among others, on the double standards of sexuality. Franklin points out that while society is prizing "extreme sensibility as highly "feminine", it simultaneously "punished any resulting impropriety in women while condoning outright libertinism in men" (xiv).

Moreover, women are kept intentionally innocent, and when suddenly confronted with the real world, they are not fit to cope, as Lamb demonstrates. In the first detailed description of Calantha, the narrator presents her as rather haughty and with much potential for self-destructive behaviour:

Her feelings indeed swelled with a tide too powerful for the unequal resistance of her understanding: - her motives appeared the very best, but the actions which resulted from them were absurd and exaggerated. Thoughts, swift as lightening, hurried through her brain: - projects, seducing, but visionary crowded upon her view: without a curb she followed the impulse of her feelings; and those feelings varied with every varying interest and impression ... It was thus, with bright prospects, strong love of virtue, high ideas of honour, that she entered upon life. (29)

Lord Avondale decides to deprive her of her Rousseauian innocence and open her eyes to see the world how it really is. Although having only good intentions in mind, namely to free Calantha from all her former restrains and oppression and thus to liberate her "true nature", Lord Avondale is all too radical:

Eager to oppose and conquer those opinions in his wife, which savoured as he thought of bigotry and prudish reserve, he tore the veil at once from her eyes, and opened hastily her wondering mind to a world before unknown. He foresaw not the peril to which he exposed her: - he heeded not the rapid progress of her thoughts - the boundless views of an overheated imagination. At first she shrank with pain and horror, from every feeling which to her mind appeared less chaste, less pure, than those to which she had long been accustomed; but when her principles, or rather her prejudices, yielded to the power of love, she broke from a restraint too rigid, into a liberty the most of dangerous from its novelty, its wildness and its uncertainty. (52-53) 
The description of her character and Avondale's act of "freeing" or "waking" his wife from a sheltered and simultaneously oppressive world is again pointing to the origin of the dilemma, the poor education of female sensibilities. Consequently, as McDayter states, "abruptly released without careful direction or instruction, Calantha indulges herself in an orgy of indiscretion and sensuality ..." ("Hysterically Speaking" 165). As a result, the liberation of these women from their chains of ignorance and naivety unintentionally leads to tragedy.

\subsection{Institutionalised vs. Passionate Love}

Lamb thus paves the way for the following explosion of female hysteria released by Glenarvon. She tries to explain why these women never had a chance to act any differently, how unjustifiable the condemnation of their behaviour actually was. She clearly sees the blame in the failure of society and in the demand to deny true love:

"From the deep recesses of a guilty, yet not humble heart, in the agony and the hopelessness of despair", said Calantha. "I acknowledge before God and before man, that for me there is no excuse. I have felt, I have enjoyed every happiness, every delight, the earth can offer. Its vanities, its pleasures, its transports have been mine; and in all instances I have misused the power with which I have been too much and too long entrusted ... Tell them I do not hope that my example can amend them: they will not turn from one wrong pursuit from me; they will not compare themselves with Calantha... Yet when they read my history - if amidst the severity of justice which such a narrative must excite, some feelings of forgiveness and pity should arise, perhaps the prayer of one, who has suffered much, may ascend for them, and the thanks of a broken heart be accepted in return." (279-278)

Having recognised her faults and taking full responsibility for them, Calantha nevertheless hopes that she will not be condemned too severely by women and hopes for their compassion and understanding.

The criticism proceeds in Lamb's depiction of marriage and love in Glenarvon. To be or to get married does not simultaneously mean to be in love; the bestdepicted marriages in Glenarvon are those which lack love. Lady Selwyn's relationship with her husband is described as an equally beneficial agreement for both parties, a secure kind of alliance. Lady Selwyn even speaks against a marriage based on love:

"After all, a wife is only pleasant when her husband is out of the way. She must either be in love, or outer love with him. If the latter, they wrangle; and if the former, it is ten times worse. Lovers are at all times insufferable; but when the holy laws of matrimony give them a lawful right to be so 
amazingly fond and affectionate, it makes one sick." "Which are you, in love or out of love with Mr. Selwyn?" - "Neither, my dear child, neither. He never molests me, never intrudes his dear dull personage on my society. He is the best of his race, and only married me but of pure benevolence ... [he] took me as his mate, because I let him play at cards whenever he pleased. He is fond of cheating, he never can get any one but me to play with him." (77)

Described here is what Graham calls a "mechanical marriage", obviously belonging into the realm of the symbolic. Lady Selwyn argues that a union that is based on love is bound to fail. She tries to explain to Calantha that the moulding into symbolic structures is necessary to ensure a successful marriage. However, this institutionalised love is connected to slavery throughout the novel. ${ }^{26}$ Images of masters, slaves, chains, but also of shackles, subservience, and obedience are continuously depicted in connection with this kind of love. Calantha proclaims that her marriage to Lord Avondale will neither cost her her freedom, nor turn her into a slave "dear as he was, her freedom was even dearer ... she would never become a slave and a wife" (49). What Calantha fails to understand is the fact that she was never free to begin with and that her husband is able command over her as he wishes. ${ }^{27}$ In Glenarvon, men hold an advantage when it comes to love. Graham argues that:

The problem with the Avondales' marriage ... arises in part because, for men, love is not enough. It may enslave for a time, but the world holds other fascinations: military affairs for Avondale... Women, especially married women, have no such recourses when the chains of love grow heavy. There is nothing to do but love again. (117)

Calantha later on recognises this circumstance and declares, "Marriage is the annihilation of love" (99).

The power relation between male and female characters as depicted in Glenarvon gives a demonstration of patriarchal values but reveal also ambivalence towards them. The "love" between Lord Avondale, as a representative of patriarchy, and Calantha is, accordingly, one based on the ideals of the symbolic. Kelly argues that love, passionate love as that between Calantha and Glenarvon is depicted as an

extra-social absolute, [a] timeless plane of experience which clearly must rival "virtue" ... and it is love very different from the love embodied in the social institution of marriage which Calantha has already experienced with

26 For a more detailed exploration of this interplay of love and slavery see Peter Graham, Ghislane McDayter ("Hysterically Speaking"), and Gary Kelly.

27 For a further discussion of the master/slave relationships in Glenarvon see Peter Graham and Ghishlane McDayter ("Hysterically Speaking"). 
Avondale, and found, as social experience is, to be merely a relative thing, not extra-social, not absolute, and certainly not timeless. (14)

Glenarvon, as a Byronic hero, is the embodiment of this extra-social love, or in other words, he belongs to the realm of the semiotic. Repressed passions and desires, some of which women were never even aware of, are awakened through his presence. Kelly proceeds with an explanation of his interpretation of Kristeva's symbolic and semiotic, in his words, the social and extra-social. He argues that the plot evolving around Calantha belongs to the private, extra-social world of passion, whereas she is surrounded by "a crowded, complex, confusing, and deceptive social world" (16).

With the appearance of Glenarvon, the plot of the novel is reduced to affairs of passion, be it relationships between men and women, or revolutionary acts. Passion, love and desire function as a bridge between male and female worlds of experiences; they reduce the plot to the interaction between men and women. In the novel the individual as well as everything belonging to the semiotic like passion, or a woman's world of experience, has to surrender and be repressed in order to comply with the symbolic structure of public, social and traditional patriarchal values. This is depicted in the love-triangle between Calantha, Avondale and Glenarvon, and through a clash of institutional love with passionate love. The symbolic and semiotic are treated in society as two separate orders, which are not supposed to collide. However, as Kristeva argues, the one cannot exist without the other; subordination to a dominant patriarchal system of social convention through neglect and repression of the "female world" of emotional experience is doomed to fail. Accordingly, under the calm surface, the heroines in Glenarvon are emotional time-bombs that are waiting to explode.

\subsection{The Byronic Hero: Catalyst of Repressed Desires}

Lamb uses the Byronic hero as the activator of the explosion of repressed female desire he is used as a form of criticism of institutionalised love and of the emotional oppression of women. Glenarvon is portrayed as a fatal seducer, a betrayer of the weak and oppressed, of women, and Irish rebels. He combines in equal measures Satanism and sexuality, which are both destructive for women, as the real Byron was. Braudy comments on Byron's power to activate the semiotic in women:

Byron is ... celebrated ... for the literary display of 'himself - a swirling whirlpool of almost sexual allure in which his audience might glimpse an image not of their public selves so much as those desires and aspirations that had seemed socially unfit or irrelevant, now writ large and grand. In letters that poured in to him ... spoke the voices of private loneliness and 
singularity in response to their public model and the catalyst of their own self-regard. (401)

Lamb condemns the Byronic hero as a libertine and criticises through this persona the sexual double standard (Glenarvon's social condemnation is incomparable with the women's condemnation, as it is does not exist virtually) but also brings him into play as a catalyst of female passion. Calantha's first meeting with Glenarvon is described as follows:

She gazed for a moment upon his countenance - she marked it. It was one of those faces which, having once beheld, we never afterwards forget. It seemed as if the soul of passion had been stamped and printed upon every feature. The eye beamed into life as it threw up its dark and ardent gaze, with a look nearly of inspiration, while the proud curl of the upper lip expressed haughtiness and bitter contempt; yet, even mixed with these fierce characteristic feelings, an air of melancholy and dejection shaded and softened every harsher expression. Such a countenance spoke to the heart, and filled it with one vague yet powerful interest - so strong, so undefinable, that it cold not easily be overcome. (118)

Many of the already discussed characteristics of the Byronic hero are included in this quotation, ranging from the "soul of passion", "dark and ardent gaze" to the immensely and immediate attraction women feel in his presence.

Calantha felt the power, not then alone, but evermore. She felt the empire, the charm, the peculiar charm, those features - that being must have for her. She could have knelt and prayed to heaven to realize the dreams, to bless the fallen angel in whose presence she at that moment stood, to give peace to that soul, on which was plainly stamped the heavenly image of sensibility and genius. (118)

A fallen angel, a hidden secret, from which she would like to cure him and give his 'soul [...] peace': all the imagery of the ever-longing, dark, mysterious, fatal and dangerous lover is here evoked.

McDayter writes that Byron has been depicted as a "dangerously seductive, even mesmeric figure who could lead the masses into unthinking political violence through the "sublime terror" of his words" ("Hysterically Speaking" 158). Accordingly, Glenarvon's appearance frees Calantha, from the first moment of their meeting onwards, from the limitations of feminine ideals which she is expected to act upon. He stands as an example for a revolt against authority that in this sense is not only confined within the limits of the Irish rebellion against their English oppressors but operates also on a different level; as a female revolution against an 
oppressive patriarchal system. ${ }^{28}$ Sir Everard, Elinor's uncle, points out that his female relatives have been acting in extreme and for him incomprehensible ways since Glenarvon's appearance:

that lawless gang - those licentious democrats - those rebellious libertines; have imposed on the inordinate folly of my wife and daughters, who, struck mad, like "gave in the orgies of Bacchus, are running wild about the country, their hair disheveled, their heads ornamented with green cockades ... and Lady St. Clare, to the same of her sex and me, the property of a recruiting sergeants employed by one of that nest of serpents at the abbey, to delude others, and all, I believe, occasioned by that arch fiend, Glenarvon. (109)

As an icon of the Irish revolution Glenarvon appears to women as a violent force of emancipation; that is the reason why a big part of his attraction for women lies in his political enthusiasm. As Judson puts it fittingly "he stimulates wives and daughters of the gentry to mutiny ... Glenarvon's presence spurs women to break out" (161). However, Helen Small demonstrates that he is more than a fatal seducer. He quickly becomes the leader of the Irish uprising against the oppressive English rule and his main impact on others is to "drive them to madness of one kind or another" (118).

Nonetheless, Lamb tries to demonstrate through Glenarvon's appearance how unprepared "proper" and "virtuous" women are for the world. Calantha, never having been harmed by a man before or confronted with sexual desire, sees men as harmless creatures. Being the innocent girl she was raised to be, the narrator describes her as follows:

All that was base or mean, she, from her soul despised; a fearless spirit raised her, as she fondly imagined, above the vulgar herd; self confident, she scarcely deigned to bow the knee before her God; and man, as she read about him in history, appeared too weak, too trivial to inspire either alarm or admiration. (30)

A virtuous girl who shrinks away from everything evil and wrong, Calantha, in her naiveté, has no understanding of the things which occur around her. Girls like her, kept intentionally ignorant, are defenceless when left on their own, too trusting, and too inexperienced. While she might not consider that other people would be able to harm her deliberately and just for the fun of it, Lamb shows how easily these girls can become prey in male games of which they understand nothing. Gondimar, an acquaintance of Calantha, describes her virtues to Viviani, Glenar-

28 Various critics have discussed that the Irish uprising is a metaphor for female oppression, a revolution against a tyrannical, patriarchal system (England). For further discussions of the Irish rebellion being a struggle for female independence see, among others, Caroline Franklin, Gishlane McDayter, and Gary Kelly. 
von in disguise. He declares him that there has never been a woman of more virtue and of whose integrity he is more convinced of than Calantha's. He ensures Glenarvon of her purity and her love for her husband and child and mentions that even the seductive Glenarvon could never intervene. Whereupon Glenarvon reacts as follows:

Viviani [Glenarvon] smiled in scorn. "Gondimar, this Calantha, this fair and spotless flower of a woman, and, as such, she must be frail. Besides, I know that she is so in a thousand instances, though as yet too innocent to see her danger, or to mistrust our sex. You have often described to me her excessive fondness for music. What think you of it? She does not hear it as the Miss Seymour's hear it, you tell me. She does not admire it, as one of the lovers of harmony might. Oh no; she feels it in her very soul - it awakens every sensibility - it plays upon the chords of her overheated imagination it fills her eyes with tears and strengthens and excites the passions, which it appears to soothe and to compose. There is nothing which the power of music cannot effect, when it is thus heard. Your Calantha feels to a dangerous excess. Let me see her and I will sing to her till the chaste veil of every modest feeling is thrown aside, and thoughts of fire dart into her bosom, and loosen every principle therein ... She boasts too of the most unclouded happiness, you tell me and of the most perfect state of security and bliss; they who soar above others, on the wings of romance, will fall. Oh surely they will fall." (67-68)

This passage functions as an indication of things to come. The Byronic hero has laid his eyes on Calantha and will make sure that she will be woken from her imaginary world of institutional love and patriarchal conventions, as he recognised the semiotic in her. He is eager to prove that virtue and purity are only facades dictated by society, and that the semiotic in Calantha cannot successfully be repressed. Regardless of the unavoidable negative consequences, her fall from society, Glenarvon is determined to free her repressed desires. The motives behind such an act are only secondary for Lamb; the important part is that she brings the focus to the fact that women are often unaware of their semiotic side. Nevertheless, too rash a discovery of the semiotic can easily lead to a catastrophic outcome, since she lacks the ability and experience to react to it. Furthermore, she can also be taken advantage of, where men know of and are familiar with both the symbolic and semiotic, women are kept ignorant. Lamb uses Viviani/Glenarvon as a link that connects the women in the novel with the semiotic, but she also uses him to demonstrate how helpless and exposed these women are when confronted with it.

Furthermore, Graham notes that Glenarvon and Avondale are to a certain extent the same man; both love and belittle Calantha. Although Lord Avondale is depicted as a loving husband, he corrupts, even if involuntarily, her innocence by 
educating her (104-105). Glenarvon, on the other hand, wants to seduce and destroy her intentionally and enjoys his corruptive power over her "Remember when a word or look were regarded by you as a crime," he says halfway through his seduction of her, " " - how you shuddered at the bare idea of guilt. Now you can hear its language with interest: it has lost its horror: Ah, soon it will be the only language your heart will like."' (193). Through the comparison of these two men Lamb makes an important point, by emphasizing the parallels of the finest and most evil men in Glenarvon, she "generalize[s] the corruption of Calantha, to make it resonate as a sort of archetypal act: what men, even truly loving men, do to women ..." (Graham 106). Graham continues to argue that the role of men in the novel is to wound women; they are reduced to "stealing, staining, and breaking feminine hearts" (106). Lamb captured in Glenarvon some of Byron's most prominent characteristics; starting with the description of his appearance and his attraction to women (which I have already quoted on page 29) she connects them with the Byronic legend and thus produces an entirely new form of the Byronic hero as such, she "defrock[ed] him of his revolutionary authority" (Judson 155). Accordingly, Glenarvon only bears a vague resemblance to Byron. She does not describe him one-to-one, as the general idea of Byron could never grasp the real man but was always a misconstruction of reality.

The duplicity of the characters in the novel suggests a love-hate relationship with the hero-villain Glenarvon. Douglass comments:

The novel condemns Glenarvon and yet seeks to emulate him. This approach/withdrawal response is mirrored in the personalities of its multiple heroine-victims. Condemned by the women he wrongs, Glenarvon still obsesses them. They each repeat the same tale of passion, bereavement, and self-destruction. ("Madness of Writing" 60-61)

Glenarvon, as a Byronic hero, is free from any kind of restrictions as such as conventions or the restraints of love:

This heart has never stoop'd its pride

To slavish love, or woman's wile;

This mind has trac'd its own career, ...

Nor, moved by love, or hope or fear, ...

Then hope not now to touch with love,

Or in its chains a heart to draw,...

A heart ...

Sees nought above, nor deigns to cast

A look away on aught below. (119)

The song he sings at his and Calantha's first meeting which tells that he could never become a slave to love, operates as a kind of challenge for women that they take up. Therefore, he radiates a very special attraction, as he is not only free from but also completely uncommitted to love. 
Judson notes that the driving force behind Glenarvon's actions is a "taste for power" as well as the "will to dominate" (163). By seducing Calantha twice and betraying her to her family, he demonstrates his undeniable power over her. Nonetheless, in the end he has to pay for his crimes. After Glenarvon has wounded Lord Avondale in a duel and tries to flee to England. However, the ghosts of all the women he has betrayed haunt him. In a nightmarish scenario, these female ghosts drive him, in an act of revenge, to insanity; hell awaits Glenarvon.

\subsection{Elinor: Denied Desires Run Wild}

The denial of the female semiotic is not the only criticism Lamb expresses through Glenarvon on the patriarchal order of society. Another critique is the struggle against oppression and tyranny. McDayter explains that according to Burkean ideology, unmanageable and dangerous appetites and damaging passions have their origin in the female body ("Hysterically Speaking" 156). Consequently, the female hysteria that is set loose as soon as Glenarvon appears is an expression of uncontrollable female desire, about which Rousseau has already warned men. All the same, McDayter proceeds to argue that a Wollstonecraftian reading of Glenarvon allows for a very different perspective on the female situation. She states that the origin of "unmanageable and dangerous appetites and damaging passions" is not an expression of female desire "but rather the horrific symptoms of sexual and political oppression manifested in her body" ("Hysterically Speaking" 157). Thus, since women are not allowed to speak publicly, to defend themselves against oppression and a patriarchal system, or to even interact within the public sphere to better their situation, their protest has no outlet and manifests itself through the female body. She concludes that it is "precisely in the sexual body of Glenarvon's suffering heroines that we can find the physical manifestation of oppression and unspoken rage" ("Hysterically Speaking"157). She uses Sigmund Freud's interpretation of hysteria to support this argument. According to Freud: "Hysteria is a disease defined by the manifestation of unspoken desire upon the body of the subject" (qtd. in McDayter, "Hysterically Speaking" 164). Consequently, women have been cultured in the "fine art of becoming hysterics" (McDayter, "Hysterically Speaking" 164). As I have already stated, the Byronic hero as a symbol of revolt, libertinism, and passion only releases the violence and uncontrollability within these women. He is not the origin of the violence but its trigger, as it lies in the oppressive, traditional structures that dictate the repression of desire in female education.

The most hysterical of all these women is Elinor St. Claire, a more emotional alter ego of Calantha who is also destroyed by her love for Glenarvon. Elinor, who was raised by nuns and grew up in a convent, is apparently the woman to whom restrictions and repressions of desire were applied the most. In an attempt 
to keep her innocent in all imaginable ways, she has to suffer the most from conventional and traditional rules. Accordingly, the most apparent demonstration of how unguided liberation causes tragedy and of how repressed desires function in the body is demonstrated through her:

But for the deep flushes which now and then overspread St. Clara's cheeks, and the fire which at times animated her bright dark eyes, some might have fancied her a being of a purer nature than our own - one incapable of feeling any of the fierce passions that disturb mankind; but her voice was such as to shake every fibre of the heart, and might soon have betrayed to an experienced observer the empassioned violence of her real character. (61)

Again, Glenarvon senses the violence of the oppressed semiotic in her nature and is eager to release it, but only in order to gratify his own (sexual) desire. However, he could not have guessed the indomitable power he set free in Elinor. Presenting himself as a liberator of oppressive structures for the Irish as well as for women, he soon loses all control over the now emancipated former nun and is horrified and disgusted by that which he cannot control. With astonishing speed, which can only be explained by the immense amount of previously repressed passion, Elinor transgresses from an innocent, virtuous girl into a wild, masculine Amazon. The first meeting between Calantha and the the new Elinor is described as following:

Elinor came near: she raised her full black eye, and gazed with fearless effrontery upon Calantha.

It was the same face she had seen a few years back at the convent; but alas, how changed; - the rich and vivid crimson of her cheek, the deep dark brown of the wild ringlets which waved above her brown, the bold masculine manners and dress she had assumed, contrasting with the slender beauty of her upright form. She was dressed in uniform ... Elinor appeared desperate and utterly hardened: her presence inspired Calantha with a mixed feeling of horror and commiseration ... (114)

The extreme change of Elinor even unsettles her creator Glenarvon "Oh Elinor, I tremble at the sight of so much cold depravity - so young and so abandoned. How changed from the hour I first met you at Glenna!" (255).

Unlike Calantha, who has scruples about surrendering herself to Glenarvon, Elinor openly becomes his mistress and loves him with an incommensurable, burning passion. Where Calantha could still feel social restrains and even tried to live a life according to these, although she has already surrendered herself to Glenarvon, Elinor is different. She frees herself irrevocably from all feminine restrictions and even dresses like a boy, as Lamb herself did. ${ }^{29}$ She pursues a more radi-

29 Lamb claimed that she had written Glenarvon at night within the space of one month, dressed in page attire. It is also known that she visited Byron during their affair dressed as a page. A friend of Byron, Robert Charles Dallas, mentions one of those meetings in disguise: "While I was with 
cal way than the other women do, by breaking drastically with everything symbolic and exchanging it for the semiotic. In this manner, she intentionally commits a crime that is judged by society as vile and disgraceful, she openly lives as Glenarvon's mistress; she gives herself over to female desire and becomes an "unnatural" woman. Moreover, she leads a clearly rebellious existence as the leader of the Irish peasants and the prophetess of the Irish revolution. Even after Glenarvon abandons her and his revolutionary followers, she keeps faith in the revolt, fights like a man in battle and sets Glenarvon's ancestral home on fire, as an act of revenge.

Nonetheless, contrary to the heroines who devoted themselves to Glenarvon, Elinor does not perish after he has abandoned her. She is the only female who refuses to be shattered by a failed romance or to make his abandonment the centre of her existence. She is, in this respect, the most emancipated of all women in the novel. Her rejection of old traditions activated through her passionate love for Glenarvon and his eventual abandonment of her lead to a complete emancipation of her mind, a breaking from oppressive conventions and poisonous love. There is no way back for her. She is obviously the most hysterical of all women, and Calantha asks herself:

"And can a few short years thus harden the heart?" she exclaimed, "was St. Claire innocent, happy, virtuous? can one moment of error thus have changed her? Oh, it is not possible. Long before the opportunity of evil presented itself, her uncontrouled passions must have misled her, and her imagination, wild and lawless, must have depraved her heart. Alive was innocent: he who first seduced her from peace, deceived her; but St. Clare was not of this character. I understand - I understand the feeling which impelled her to evil. Her image hounds me. I tremble with apprehension. Something within me seems to warn me, and to say that, if I wander from virtue like her, nothing will check my course ... my ungoverned will has hitherto, my only law". (116-117)

In her pursuit for freedom, Elinor is clearly depicted as a Byronic heroine. In the end, she commits a Sappphoesque suicide when she leaps on horseback over the cliff into the sea and theatrically dies. Until then, she is defiant and unbowed and vehemently refuses to go back to her existence as a passive bystander and victim of a patriarchal society that had the power to lock her up in a convent.

Judson argues that Elinor's commitment to the Irish rebellion is depicted as pitted against Glenarvon's vocation of treachery for the Irish cause and is thus an assault against Byron and Whig society. Furthermore, she states that at first ap-

[Byron], the Lady's page brought him a new letter. He was a fair-faced, delicate boy of thirteen or fourteen years old, whom one might have taken for the lady herself. He was dressed in a scarlet hussar jacket, and pantaloons... He had light hair curling about his face, and held a feathered hat in his hand which completed the scenic effect of this urchin Pandarus. I could not bust suspect at the time that it was a disguise" (qtd. in Jenkins 57-58). 
parent similarities between Elinor and Lamb herself could be noted as they both (supposedly) played Byron "because she, too, is a darkly alienated poet, known to have been Glenarvon's mistress, thus set apart by obligatory crime and guilt" (166). However, Judson continues, differences become more and more apparent. Elinor starts to function as the "authenticity of Gaelic culture in stark opposition to the mummery of the Byronic hero" (166). Correspondingly, it has been argued that Lamb empathised with the political emancipation of Ireland and its longing to liberate itself from a too domineering England, since she recognised parallels between the repression of the Irish and the female struggle for autonomy. ${ }^{30}$ Consequently, the Irish rebellion against the English in Glenarvon has been read as a metaphor for a female revolt against an oppressive patriarchal system; both have been caused by the appearance of the Byronic hero.

Elinor's function as a Byronic heroine has barely been commented on although it is noticeable. Judson states that, in a real Byronic fashion, she renounces every conventional rule, starts to wear men's clothing, shatters her obligation of filial obedience, and chooses to live under her dying father's condemnation rather than going back to old values and restrictions (167). She possesses enough passion and devotion for the Irish cause to gain the rebels' confidence and to qualify as their leader. She is, like the Byronic hero, a fighter for justice who actively considers isolating herself from society in order to gain freedom. Nevertheless, Judson concludes "where the Byronic hero's "involuntary fault" is presented as confirmed hypocrisy and self-seeking mobility, St. Clare's rebellion against the corrupt institutions of family, colonial society, and British power is commended as heroic martyrdom in the best tradition of Roman virtue" (169). Where Glenarvon functions as the Byronic hero gone berserk, Elinor is his counterbalance, a fighter for equality and against oppression; as someone who detached herself completely from everything, whether they be conventions, or even love. Thus she says to Glenarvon:

"Alice dead - Calantha discarded! I heard the tale, but it left no credit with. - Can there be hearts so weak as thus die for love? ... [B]y thyself, thy [Glenarvon's] glorious self, I swear I will never return to virtue ... by these eyes ... by these shining looks ... by these lips, which prest by yours, have felt the rapturous fire and tenderness of love - virtue and I are forsworn: and in me, whatever I may appear, henceforward know that I am your enemy." (255-256)

However, critics have commented that there was no place for such an independent woman in English Regency society and that the future "holds no place for this proleptic figure of sexual and political liberty, who remains a prophet without honor in her own country" (Judson 168). ${ }^{31}$

30 For a further discussion see Barbara Judson and Ghishlane McDayter ("Hysterically Speaking").

31 See Ghislaine McDayter and Barbara Judson among others. 
Her end is thus anticipated. Elinor's fate clearly functions as a forewarning of how women are treated in society. It demonstrates how sexual repression affects the psyche. She personifies the consequences of the explosion of too long denied desires, the violence which occurs through this release. Elinor chooses to die rather than to rehabilitate herself in the eyes of society by conforming to the expectations of society. As McDayter describes it "death is the only alternative to slavery in this brutal world ruled by the "law of father" "Hysterically Speaking", 170). After setting fire to Glenarvon's ancestral home

she pressed the spur into his sides, and galloped in haste to the edge of the cliff, from which she beheld, like a sheet of fire reddening the heavens, the blazing turrets of Belfont. She heard the crash: she gazed in triumph, as millions of sparks lightened the blue vault of heavens; and volumes of smoke, curling from the ruins, half concealed the ravages of insatiate flame ... The waves of the foaming billows now reflected a blood-red light from the scorching flames ... (349)

Seeking her watery grave voluntarily, she chooses freedom over slavery, the semiotic over the symbolic. The theatrical setting, a fire-red sky, the wild, troubled ocean symbolise the tumult of her passion, the unspoken rage within that can never be controlled again. The flames can easily be read as a flaming sexual desire, which can also never be fulfilled. Accordingly, her suicide is her own kind of victory.

Graham argues that Glenarvon's heroines are doomed to failure and death, because they have to pay for their error, and the nineteenth-century novel demands such a punishment (102). However, I agree with critics like McDayter and Judson, as they argue that Lamb recognises the dangers of the repression of desires and knows that desire, if not expressed, will articulate itself through the female body. Women's radical breaking with conventions in Glenarvon, Elinor's inconsiderate giving in to the semiotic, the self-destructiveness of Calantha's and Elinor's passion, all this points to a reflective discussion of repressed desire.

\subsection{Conclusion}

Critics have tried to depict Lady Caroline Lamb as a hysterical woman in need of mastery, a concept that is not uncommon in Romantic criticism. She has also been reduced to a love-mad woman who wrote a novel as an act of revenge. Her work has been diminished to a biographical account of a very public affair so that the social criticism on gender power relations has been ignored. However, as I have tried to demonstrate, the origin of Lamb's supposed madness lay not in her incapability to rest but in society's prohibition of the female semiotic and in Byron himself. 
Lamb demonstrates in Glenarvon how passion and desire will find a way to break free and take over the body and mind. She uses the literary persona of the Byronic hero as a trigger and catalyst of female passion. Simultaneously, she transforms him through her own personal experienced with Lord Byron, and presents him as an inconsistent, fatal and cruel, but charismatic lover, who arouses female desire to such an extent that it can neither be repressed nor ignored. She not only started a new literary tradition by using the dangerous love for the first time in a novel, her depiction of this persona would become one of the most popular Byronic features in novels. Furthermore, other female writers would use the persona to criticise gender roles.

Lamb sees the origin of the "female dilemma" in an insufficient education. Avondale's and Glenarvon's attempt to reveal the "true" woman within from artificial social and cultural restrictions such as education, law, and social class, demonstrates how the idea of femininity has been forced upon women. Lamb exposes the oppressive power of the patriarchal system and its capability to repress women's semiotic side. Thus, Lamb's interest lies not in the punishment of the heroines' failure to resist the sexual temptation through remorse but in the emotional understanding and experiences of the "female world" that is oppressed by a patriarchal rule of social convention. The women in her novel had no other chance than to fail, as their education and traditional conventions prohibited them to learn reason, so that they acted on their desires only. Accordingly, Glenarvon is a presentation of the inevitable interaction between the symbolic and semiotic, a demonstration that neither order can stand alone. It is a depiction of the relationship between conventional patriarchal social values, the private world of passionate feeling and the consequences of being forced to comply with the symbolic only.

\section{Charlotte Brontë's Jane Eyre}

\subsection{Feminist Criticism}

Since its publication in 1847, Jane Eyre has been considered to be a novel that speaks particularly to women and about womanhood. In the twentieth century it became an iconic text in feminist criticism, which reads it as a woman's quest for independence and equality. From childhood on, Jane Eyre struggles to recount her own story, in order to defend and explain her life's choices, which are far from conventional, but also to let her voice be heard at a time when women were not supposed to have a voice of their own. Jane, however, dares to talk back and thus liberates herself from the repressing symbolic order. C.Kaplan states that feminist criticism has read Jane Eyre as a "revolutionary manifesto" as Jane is able to "nar- 
rate (if not direct) her own story" (72). Traditionally, the novel is seen as a form of resistance, or, as Gilbert and Gubar state, as "a pattern for countless others ... a story of enclosure and escape of difficulties Everywoman in a patriarchal society must meet and overcome" (256). Nevertheless, Jane also has to live within a patriarchal system in which she is expected to repress her desires. Although she is one of the first heroines to recognise and admit those desires, she needs a Byronic hero before she is able to free herself from oppressive conventions and let her passions free.

One of the first critics to note the new concept of this female selfdetermination in Brontë's novel was a contemporary of Brontë, Margaret Oliphant, a Scottish novelist and historical writer. She was the earliest critic to identify Jane Eyre as a transformation within the female tradition of writing, as Jane is more aggressive, independent and demanding than any female protagonist before:

Nobody perceived that it was the new generation nailing its colours to the mast. No one would understand that this furious love-making was but a wild declaration of the 'Rights of Woman' in a new aspect. (557)

Oliphant, although she recognises the new dynamics between men and women that the novel presents, vehemently criticises Brontë's radicalism in the novel, arguing that it gives young women a wrong impression of courtship and marriage.

In "A Room of Ones Own" (1929) Virginia Woolf saw Brontë as one of the women who had set the stage for the acceptance and recognition of female writers and their work. Yet she judges Brontë's writing as containing too much anger and rage in her authorial voice that she sees as a distortion of the narration. As Showalter comments on Brontë: "[P]erhaps no other writer of her time has impressed her mark so clearly on contemporary literature, or drawn so many followers onto her own peculiar path" (87). Either way, Brontë's Jane Eyre has a special significance in feminist criticism.

At a time when women were supposed to keep strictly within the bounds of female decorum in their writing, both in style and subject, an obvious double standard in literary works can be found. Accordingly, critics judged the literary works of female writers differently than those of their male counterparts. Consequently, female writers used male pseudonyms when publishing their works. During the mid-Victorian era, women had only few opportunities for using their talents to express their true identities. It was expected that they would be content with their lives within a confined and limited sphere; when in fact these restrictions and confinements drove many of them to madness by prohibiting their selffulfilment. In Jane Eyre Brontë demonstrates that all women are symbolically disinherited in a patriarchal society and that they have only a limited number of options to come to terms with their lot. A woman could forsake all worldly aspirations and pleasures and thereby deny her self, as the examples of Helen Burns and Eliza Reed show who retreat into the promises of religion. Alternatively, they 
could try to catch a husband who would care for them, as Georgina Reed and Blanch Ingram choose to do. In contrast to those two choices, Jane finds a way to express herself and to eventually balance her desires, which become almost overbearing with the appearance of Rochester, so that she is no longer able to ignore them and act within expected norms.

When Jane Eyre appeared in 1847 critics were eager to find out if Currer Bell, Brontë's pseudonym, was a man or a woman. Showalter comments that the character of Rochester in particular provoked a whole range of negative criticism ranging "from bafflement to horror" (115). ${ }^{32}$ Even though he was a convincing character, it was argued that no decent girl could ever love this brutish hero. Still, in the novel exactly such a girl loves him. Where men saw Rochester as tyrannical, female novelists recognised the value of such a hero, since the "brute flattered the heroine's spirit by treating her as an equal rather than as sensitive, fragile fool, who must be sheltered and protected" (Showalter 117). Even though Brontë confessed to her friend James Taylor that she had had difficulties in constructing a male character, her creation is still considered to be one of the most popular male protagonists in English literature:

In delineating male character, I labour under disadvantages; intuition and theory will not adequately supply the place of observation and experience. When I write about women, I am sure of my ground - in the other case I am not so sure. (qtd. in Showalter 109)

Rochester's character, however, was not as new and innovative as Showalter depicts it to be. He is actually a remnant of the previous Romantic period, since he is a direct descendent of Lord Byron's protagonists. Byron's influence on the Brontë sisters is indisputable; various forms of the Byronic hero pervade their works. Their idea of love in particular, as vital to give meaning to life and as fatal and as burdened with guilt, is a Byronic concept. Moglen even argues that the articulated ambitions of the original Byronic hero could be considered to be "the repressed needs and feared passions of Charlotte's "other" self" (26). She continues by pointing out that when Charlotte first heard of Lord Byron he had already died and his name had been linked interchangeably with everything that was prohibited and audacious. Nevertheless, as Gérin argues, Brontë provides her heroes with

32 Brontë however defends Mr Rochester against his critics: "Mr Rochester has a thoughtful nature and a very feeling heart; he is neither selfish nor self-indulgent; he is ill-educated, misguided; errs, when he does err, through rashness and inexperience; he lives for a time as too many other men live, but being radically better than most men, he does not like that degraded life, and is never happy in it. He is taught the severe lessons of experience and has senses to learn wisdom from them. Years improve him; the effervescence of youth foamed away, what is really good in him still remains. His nature is like wine of good vintage; time cannot sour, but only mellows him.” (Charlotte's Letter to W.S. Williams 14 August 1848 in: Wise, Thomas James and John Alexander Symington (Eds), The Brontës. Their Lives, Friendships and Correspondenc. Oxford: Basil Blackwell, 1989.) 
every Byronic characteristic and theme, such as "love, jealousy, treachery, ambition, courage, pride and daring", as well as with "quality satanic ruthlessness and demonic power" (2-3).

\subsubsection{An "Unwomanly" Woman}

The presentation of female desire in Brontë's novel outraged many readers. The novel addresses the stigmatization of female desire, as it does not depict Jane as a mere passive being or as a sexual, demonic assailer. The novel raises the awareness of the difficulties women had to communicate their desire. Female novelists challenged and questioned the codes of female behaviour through their depiction of fictional female characters. They tried to create a counter motion to advice literature that tried to regulate female behaviour. Mitchell and Osland comment that during the sixteenth century

women where regarded as inherently sexually voracious, driven by bodily desires that their inferior rational powers struggled to control, advice literature emphasized ... prohibitions that would establish a system of behavioural defences, chief amongst these being the scriptural case for obedience which men saw as the basic resolution to women's wiles and weaknesses. (6)

They continue by pointing out that from the 1630s onwards, conduct books changed their course from proclaiming that the dangers of female sexuality could be avoided through submissiveness to men by focusing more on female "modesty":

A modesty that in its broadest sense is no different form the moderation earlier enjoined on women in subjugating themselves to masculine authority as a 'due master' of their inferior status, but increasingly understood, or at least increasingly discussed, more narrowly as a personal delicacy that prompts a woman to shrink from notice or self-assertion. (6)

With the help of advice literature, critics could thus reconstruct the development of the "image of woman as lustful, loquacious, and wilful to one that is naturally rather than prescriptively chaste, silent and obedient" (6). The alteration from the idea that women's sexuality should be regulated through male authority to the concept that all women are naturally delicate, sensitive and modest, and that they instinctively shrink back from sexuality did not mean that one idea of femininity replaced the other. Mitchell and Osland argue, "in the social construction of womanhood, beliefs seem to have accumulated in layers" (7). This is why women on the one hand could be condemned as demonic, voluptuous and wilful beings 
and why, on the other hand, the existence of female sexuality could be denied altogether. ${ }^{33}$

Jane Eyre questions basic institutions and concepts of a bourgeois patriarchal society and can thus be considered to be a "ringleader of a feminist revolt against its stifling conventions" (Mitchell and Osland 175). It was Jane's discontent that drew the most fervent protestation, as she seemed unable to appreciate the "simple duties and pure pleasures" of a "proper" woman. The very temperament of Jane's passions, such as falling in love with her master Mr Rochester was judged as inappropriate, and having such passions at all was considered as indecent (Mitchell and Osland 177).

In this regard, Jane Eyre is a highly unconventional novel, as Jane declares her independence as an individual who will not be governed by conventions and traditional patriarchal beliefs, but only by her own conscience. However, she only narrowly escapes the charm of the Byronic hero who almost tempts her into living like him, ignoring and flouting divine power and laws. Ewbank notes that "measured against the criterion of womanliness which states that the pure feminine mind must, even theoretically or imaginatively, know no sin, no evil, no sexual passion [Jane Eyre and even Charlotte Brontë] could not but seem 'unwomanly"' (42). The very questioning of the established gender roles was thus seen as unfeminine, improper and scandalous.

It is difficult to assign the novel to a particular genre as it unites the romance with the woman question and various other social themes, such as class, patriarchy and religion. Jane Eyre voices the female hunger for sexual experiences and tries to provide a surrounding in which the expression of these sexual desires might be made possible and in which women are not condemned as mad when experiencing sexual urges.

Brontë gives a demonstration of the symbolic and semiotic order by placing characters in either the one category or the other. She thus reveals the dangers and consequences those orders hold for women if they are forced or chose to comply with only one. Jane will be confronted with a semiotic force in form of Mr Rochester, the Byronic hero who acts as a catalyst for Jane's strong inner sexual desires. She almost loses herself in both, the semiotic and symbolic, as she has difficulties resisting male sexual power, but eventually finds a way to balance these two orders.

33 Maynard comments that Michel Foucault was one of the first critics who concluded in his History of Sexuality that the Victorians were, contrary to popular belief, rather concerned with the subject of sexuality. It had been believed that within the Victorian period, sexuality was a topic which had been completely ignored. Foucault corrects this view when he discusses that on the one hand there were those who discussed the matter of sexuality quite openly, and on the other hand were those Victorians who vehemently ignored or even denied the matter of sexuality. Either way, the Victorians were obviously engaged in a ubiquitous discourse of sexuality (vii). Yet, the term Victorianism is still connected with the idea of repressed or ignored sexuality. 


\subsection{Symbolic and Semiotic}

Jane's development into a woman in nineteenth-century England is described powerfully and is worth to be carefully looked at. From childhood on, she is unable to comply solely with the symbolic, as the semiotic always forces itself to the surface. One of the most profound innovations of Jane Eyre, however, is the depiction of the symbolic and semiotic by dividing the characters' psyche into two parts of mind and body. This is illustrated through two contrasting characters: Helen Burns and Bertha Mason. These two women can be seen as the embodiment of the "unyieldingly dualistic" Victorian attitude towards female sexuality. While Helen is a clear personification of the symbolic, her counterpart Bertha is the personification of the semiotic. While Helen and Bertha are prominently read as two faces, or alter egos, of Jane, my reading of these two female characters will be focused on their role as the embodiments of the two orders and the resulting inescapability of their demise. These polar personalities serve Jane as warning against the separation of the symbolic and semiotic.

\subsubsection{Jane’s Inner Struggle}

Although raised in a patriarchal, symbolic tradition Jane's growth from child to woman is marked by unexpected and unparalleled outbursts of the semiotic in the form of rage and revolt against her oppressors, namely her cousin John Reed and her aunt Mrs Reed. When Jane defends herself against John's violent assaults, she is locked up in the red room, where she experiences a hysterical fainting fit. Gilbert and Gubar comment that the red-room experience induces Jane to withdraw into herself. They argue that the room, which was "stately, chilly, swathed in rich crimson, with a great white bed and an easy chair 'like a pale throne' looming out of scarlet darkness, perfectly presents her vision of the society she is trapped in" (257). It appears to me, however, that, instead of forcing Jane into herself, this incident marks the end of her submission to authorial power and introduces a new chapter in her life. When she wakes up, she carries the knowledge of the absolute necessity to protect herself against the symbolic. She realises that she needs to care for herself, as nobody else will do so. Furthermore, while defending herself against her cousin, as well as in the red room she experiences a previously unknown aspect of herself, an almost animalistic rage and passion. As Moglen notes, Jane awakens to a new "capacity of moral judgment and nascent senses of the self" (111).

While Gilbert and Gubar discuss Jane's following outburst against Mrs Reed and the corresponding comments of "something burst out of me" (13) and "a sound filled my ears, which I deemed the rushing of wings; something seemed near me" (14) as a suggestion of the existence of a "dangerous double consciousness" (Gilbert and Gubar 260). I rather understand her rebellion and outburst as 
her perception that a compliance with the symbolic will end in a life full of oppression and ultimately in the loss of the self in patriarchal traditions. In order to prevent this from happening, she needs to stand up against her aunt Mrs Reed, who acts as a representative of the patriarchal system. Thus, Jane confronts her:

Speak I must; I had been trodden on severely, and must turn; but how? What strength had I to dart retaliation at my antagonist? I gathered my energies and launched them into this blunt sentence:

"I am not deceitful!"...

"I am glad you are no relation of mine ... You think I have no feelings and that I can live without one bit of love or kindness; but I cannot live so and you have no pity ... And that punishment you made me suffer because your wicked boy struck me - knocked me down for nothing ... You are deceitful!"' (31-32)

Jane tells the reader that

Ere I had finished this reply my soul began to expand, to exult, with the strangest sense of freedom, of triumph, I ever felt. It seemed as if an invisible bond had burst, and that I had struggled out into unhoped-for liberty. Not without cause was this sentiment; Mrs Reed looked frightened. (31)

The child Jane already feels that she must stand up against the injustice and discrimination that she experienced at her aunt's house, despite her youth and indoctrinated submissiveness. Jane's semiotic side cannot be fully suppressed and surfaces over and over again. A dialogue between passion and reason, feeling and judgment, impulse and conscience, fire and ice starts.

\subsubsection{Female Education: or the Oppression of Female Sexuality}

After the outburst Mrs Reed sends Jane to Lowood School; a place where female sexuality is systematically diminished and repressed. Mr Brocklehurst, the director of the school, acts as an example of tyrannical and cruel male authority. He is the embodiment of institutionalised oppression that is based on class and sexual prejudice, a representative of the symbolic. He represents the abusiveness and oppression that women have to endure in a patriarchal society.

As various critics have noticed, Brocklehurst is presented as the evil wolf in Charles Perrault's "The Little Red Riding Hood." 34 He is a mixture of the devil himself and the evil wolf, a devourer of everything innocent. Gilbert and Gubar have stated how Mr Brocklehurst is the perfect example of the "Victorian superego" (260), because of his description in evident phallic terms during Jane's and his first encounter:

34 See Sandra Gilbert and Susan Gubar, Cyndy Hendershot, and Huang Mei among others. 
The handle turned, the door unclosed, and passing through and curtseying low I looked up at - a black pillar! Such, at least, appeared to me, at first sight, the straight, narrow, sable-clad shape standing erect on the rug: the grim face at the top was like a carved masked, placed above the shaft by way of capital. (26)

Hendershot points out that the fairytale of the "Little Red Riding Hood" has been read as a tale of female sexual initiation, consequently she sees Brocklehurst's comparison to the evil wolf as an act of sexualizing him and simultaneously presenting the "image of masculine sexuality as animalistic and dangerous" (167). His sexualisation is further emphasised by an imagery of a personified erection "it was Mr Brocklehurst, buttoned up in a surtout, and looking longer, narrower, and more rigid than ever" (58). Accordingly, male sexuality is presented as threatening. His function as an oppressor of female sexuality is emphasised through his speeches, for example, when he explains his actions to Miss Temple:

I have a Master to serve whose kingdom is not of this world; my mission is to mortify in these girls the lusts of the flesh, to teach them to clothe themselves with shame-facedness and sobriety - not with braided hair and costly apparel; and each of the young persons before us has a hair twisted in plaits which vanity itself might have woven; these, I repeat, must be cut off; think of the time wasted, of - . (56)

He systematically tries to desexualise the orphans who are entrusted to his care and his "obsession with feminine sexuality fuels Jane's sexualisation of his authorial power" (Hendershot 167). Presenting himself as a pious and spiritual man, he is an example of how men used religion to justify the imposition of their worldview on women and the poor.

At Lowood, the girls are not only starved to death but they are also denied all kinds of sensual pleasures. Signs of their femininity are methodically destroyed, as they are all clothed in the same brown dresses and deprived of their hair, which is their last symbol of their femininity. At school, they are supposed to be taught the kind of chastity that their future lives will require. Brocklehurst is on a mission "to mortify in these girls the lusts of the flesh"; he tries to accomplish this task by destroying not only the girl's individuality but he simultaneously "punishes and starves their sexuality" in order to "create an intensely spiritualised creature", namely "the angel in the house" (Showalter 97) while simultaneously representing masculine sexuality.

\subsubsection{The Self-Destructiveness of the Angel in the House}

Helen Burns represents the angel in the house and is thus a "perfect ... representation of the feminine spirit in its most disembodied form" (Showalter 97). Helen 
is the ideal victim for Brocklehurst's method of education, as she is pious, patient and submits completely to the symbolic order. She endures unjust punishment uncomplainingly, forgives the teacher's cruelty and entirely acknowledges the legitimacy of their punishment. Helen appears like a living martyr; her desire for death however, demonstrates how the total compliance to the symbolic results in violence against the self. Her total submission to her oppressors eliminates any kind of self-preservation; as a result, she is convinced of her inadequacy and her guilt for not being able to live up to their expectations leads to this desire for death. Thus, Helen's submissiveness and inability to live within the symbolic order let her consider death as her only chance of happiness:

No ill usage so brands its record on my feelings ... We are, and must be, one and all, burdened with faults in this world; but the time will come soon when, I trust, we shall put them off in putting off our corruptible bodies when debasement and sin will fall from us with this cumbrous frame of flesh, and only the spark of the spirit will remain, the impalpable principle of life and thought, pure as when it left the Creator to inspire the creature: whence it came it will return - perhaps again to be communicated to some being higher than man - perhaps to pass through gradations of glory from the pale human soul to brighten to the seraph! Surely it will never, on the contrary, be suffered to degenerate from man to fiend? No; I cannot believe that; I hold another creed, which no one ever taught me, and which I seldom mention, but in which I delight, and to which I cling; for it extends hope to all; it makes Eternity a rest - a mighty home, not a terror and an abyss. Besides, with this creed, I can clearly distinguish between the criminal and his crime, I can so sincerely forgive the first while I abhor the last; with this creed, revenge never worries my heart, degradation never too deeply disgusts me, injustice never crushes me too low. I live in calm, looking to the end. (50-51)

This passage shows how completely Helen has given up, not only on herself but also on the world; consequently, she almost excessively waits for her death to come.

Jane admires Helen's attitude immensely, and it has a deep impact on her: "It was as if a martyr, a hero, had passed a slave or victim, and imparted strength in the transit" (58). Helen's martyrdom however, is presented as saintly and at the same time as self-abnegating. Although she serves also as an example to instruct Jane in the virtues of patience, endurance and selflessness, her patience implies "a rational submission to the repressive conventions of Lowood, which she does not challenge" as well as a "resigned endurance of life as a burden from which will come release" (Eagleton 15). Eagleton sees in Helen's heroism a "heroic selfaffirmation" that is "a realization of the self through its inner surrender" (16). As her name a suggest, Helen "Burns" within; her suffering and religious passion 
indicates a renunciation of the (symbolic) world. Because of the complete denial of the importance of worldly desires, her passions are forced to consume themselves and her in an inward fire. Her absolute rejection of desires results in an internal self-immolation. She complies and tries to obey the laws of the symbolic at such an excessive degree that it becomes her vanishing point. In the end, she prevails over oppressive and tyrannical conventions. Her victory, however, is won through her early death, as this is the only way for her to escape the symbolic; her death frees her from all potential suffering.

Helen is not the only one who teaches Jane self-discipline. Miss Temple, the superintendent at Lowood School, is one of the few positive female role models who treat Jane with respect and compassion. After Helen's death, she becomes Jane's only friend and as long as she stays at Lowood Jane can pretend to be content, however:

From the day she left I was no longer the same: with her was gone every settled feeling ... I had given in allegiance to duty and order; I was quiet; I believed I was content: to the eyes of others, usually even to my own, I appeared a disciplined and subdued character ... I had undergone a transforming process; my mind had put off all it had borrowed from Miss Temple - or rather that she had taken with her the serene atmosphere I had been breathing in her vicinity - and that now I was left in my natural element, and beginning to feel the stirring of old emotions. (73)

Her former calmed discontent makes itself felt again and she knows that she cannot oppress or ignore them once more: "I felt that it was not enough: I tired of the routine of eight years in one afternoon. I desired liberty; for liberty I gasped; for liberty I uttered a prayer" (74). Here she realises that she could never be content with complying to the symbolic and that she wants more from life: “'Then,' I cried, half desperate, 'grant me at least a new servitude!'” (74).

She also desires independence and the longing for and acquiring of it is another important motif of the novel. For an unmarried woman independence is, in a wider sense, a matter of status and affects her self-esteem and personal identity.

\subsubsection{Repressed Desires Run Wild: or the Mad Woman in the Attic}

Where Helen Burns is the embodiment of the symbolic, Mr Rochester's wife Bertha Mason who is confined to the third story of Thornfield because of her madness is an embodiment of the semiotic. She stands as a symbol for suppressed female sexuality and through her Brontë raises the awareness of the amalgamation between sexual suppression and its consequence, namely madness. Various critics have argued that Bertha functions as Jane's dark alter ego (Gilbert/Gubar), or as an exemplum of the dangers of sexuality (Maynard). Like Helen, Bertha represents the Victorian discourse of female sexuality; she is the supposedly dangerous side, 
the wilful female, the fallen woman whose sexual hunger drives her into madness. However, it appears useful to discuss Bertha's madness both as unregulated female desire and as a consequence of patriarchal suppression of female sexuality. She embodies everything a woman had, according to the symbolic, to suppress, but yet in Jane's own words "could neither be expelled nor subdued by the owner" (185). Furthermore, Bertha functions also as a warning against complying fully with the semiotic, as a warning against having nothing of the passion controlling symbolic within oneself.

As Showalter comments, Bertha is the incarnation of the flesh, of "female sexuality in its most irredeemably bestial and terrifying form" (98) that is "a potential dangerous force that must be punished or confined" (98). Thus, Bertha's madness can also be translated into unregulated sexual desire. Female sexual appetite was considered as something unwomanly, even bestial. When Jane meets Bertha for the first time, the later is not even considered as a human being but is associated with a wild and dangerous animal that cannot be constrained:

In the deep shade, at the further end of the room, a figure ran backwards and forwards. What it was, whether beast or human being, one could not at first sight, tell: it grovelled, seemingly, on all fours; it snatched and growled like some strange wild animal: but it was covered with clothing and a quantity of dark, grizzled hair, wild as a mane, hid its head and face ... the clothed hyena rose up, and stood tall on its hind feet. (258)

Bertha embodies the resistance and defiance of repressive, symbolic cultural notions and gives herself fully to the semiotic that is expressed through an animalistic and masculine violence against others:

The maniac bellowed: she parted her shaggy locks from her visage, and gazed wildly at her visitors. I recognized well that purple face - those bloated features ...

'Ware!' cried Grace. The three gentlemen retreated simultaneously. $\mathrm{Mr}$ Rochester flung me behind him: the lunatic sprang and grappled his throat viciously, and laid her teeth to his cheek: they struggled. She was a big woman, in stature almost equalling her husband, and corpulent besides: she showed virile force in the contest - more than once she almost throttled him, athletic as he was. He could have settled her with a well-planted blow; but he would not strike: he would only wrestle. At last he mastered her arms; Grace Pool gave him a cord, and he pinioned them behind her: with more rope, which was at hand, he bound her to a chair. (258)

The paragraph does not even depict her as a woman but as an uncontrollable, wild animal which needs to be conquered as it is otherwise a threat to society.

Bertha embodies everything that lies beneath acceptable femininity. Her animal appearance and behaviour however, are the very consequence of her impris- 
onment and not its cause; or, as Showalter argues, "after ten years of imprisonment she has become a caged beast" (100). She is presented as a being that consists so thoroughly of passions and desires that it has lost its humanness. Not being able to repress these passions and desires any longer, they plunge out of her uncontrollably. She represents everything that could disrupt the symbolic in an extent that appears abjected; she is not able to articulate herself but through eccentric murmurs, threatening growling and snapping sounds - even her laugh is preternatural. All these sounds recall Kristeva's concept of the "semiotic chora" that is an essential part of the semiotic.

Her rage is shown through an emphasis on her 'big', 'corpulent' and 'virile' body that is linked with an extreme fury and a want for vengeance against her oppressors. As Bronfen notes, Bertha presents the female body as the dangerous "Other" to men; she is described as "cunning and malignant lunatic, maniac, monster, wild beast goblin and fury" (221). Her body is described as monstrous, as polluted and "mad, bad and imbruted" because of her Creole heritage (221). She is equally excessive as Helen is and falls short of the expected code. She stands as a symbol for the pure, uninstructed, diffuse, aggressive and sexual drives that constitute the semiotic and that must be controlled and restrained. Through the fire she sets at Thornfield Bertha tries to destroy the external, the symbolic that held her captive. Bronfen argues that Bertha's death states that she had to finally give into the "exertion that [her] body is equally termed by others as socially defective and physically corrupt" (222).

That Bertha was meant to be a critique on standing social gender bias and not as a critique on female sexuality is further underlined by in a comment by Brontë herself:

[Bertha's] character is shocking... [but] profound pity ought to be the only sentiment elicited by the view of such degradation, and equally true is that I have not sufficiently dwelt on that feeling; I have erred in making horror too predominant. (qtd. in Smith, Letters 3)

Accordingly, Bertha's example reveals both the sheer impossibility to comply solely with one order, as this eventually leads to death, which she has in common with Helen. It also reveals Brontë's warning of the violent force of denied desires which will ultimately explode.

Two alternatives of behaviour have been presented to Jane in the form of Helen and Bertha. First, the angel in the house, whose required angelic innocence lead to death. Secondly, she encounters a wild and uncontrollable woman, who lost herself in the semiotic, which leads to social rejection, imprisonment and in the end to death. However, it is important to notice that Bertha's total compliance with the semiotic is a result of the symbolic, whose required sexual suppression led to Bertha's madness. 
By assigning Helen and Bertha to the two contrasting orders, Brontë is able to criticise the contemporary discourse of the polar aspects of female sexuality and to demonstrate the risk women are exposed to if forced to comply to the symbolic only. Either they die because of repressed passions devouring them from within, or their desires find a way to break out of them uncontrollably so that they become mad and destructive. These two choices are presented to Jane, and although she knows what is expected of her, namely to become a second Helen Burns, to be submissive, patient and content, she has seen the dangers of such a compliant behaviour and rejects it. The other extreme however, to become like Bertha and give into her desires, is equally daunting.

\subsection{The Byronic Hero: Catalyst of Denied Passions}

Jane's departure from Lowood is not only a change of place but also temporarily the end of the dominance of the symbolic. At her arrival at Thornfield, she enters into the semiotic realm. Standing at the battlement of Thornfield and longing for more than a woman in her position can expect, for "a power of vision which might overpass that limit; which might reach the busy world ... I desired more of practical experience than I possessed", Jane addresses the reader:

Who blames me? Many, no doubt; and I shall be called discontented. I could not help it: the restlessness was in my nature; it agitated me to pain sometimes ... It is vain to say human beings ought to be satisfied with tranquility: they must have action; they will make it if they cannot find it. Millions are condemned to a stiller doom than mine, and millions are in silent revolt against their lot. Nobody knows how many rebellions besides political rebellions ferment in the masses of life which people earth. Women are supposed to be calm generally: but women feel just as men feel; they need exercise for their faculties, and a field for their efforts as much as their brothers do; they suffer from too rigid a restrain, too absolute a stagnation, precisely as men would suffer; and it is narrow-minded in their more privileged fellow-creatures to say that they ought to confine themselves to making puddings and knitting stockings, to playing on the piano and embroidering bags. It is thoughtless to condemn them, or laugh at them, if they seek to do more or learn more than custom has pronounced necessary for their sex. When thus alone, I not unfrequently heard Grace Poole's laugh. (95)

Jane's realization that the new servitude could not slake her inner restlessness paves the way for her to experience the semiotic.

After being confined within the symbolic and refusing to surrender to it, at Thornfield she will be confronted with a semiotic force that she cannot resist and that excites her deepest desires, and passions: the Byronic hero. All through her 
stay at Thornfield, a gothic setting underlines a certain dangerous and uncanny atmosphere; yet, Jane strongly renounces her fancies by trying hard to rely on reason only. This effort is scattered by the arrival of Mr Rochester. Her already acknowledged passions and desires are catalysed through his appearance to such an extent that Jane has to struggle hard in order to not lose herself completely in the semiotic.

The first description that Mrs Fairfax, the housekeeper at Thornfield, gives Jane of her new master already establishes Rochester as a Byronic hero: "[h]is character is unimpeachable, I suppose. He is rather peculiar, perhaps: he has travelled a great deal, and seen a great deal of the world, I should think. I daresay he is clever" (92). When Jane asks her, in what way Rochester is peculiar Mrs Fairfax answers:

I don't know - it is not easy to describe - nothing striking, but you feel it when he speaks to you: you cannot be always sure whether he is in jest or earnest, whether he is pleased or the contrary; you don't thoroughly understand him, in short - at least, I don't ... (92)

As numerous critics have already pointed out, Jane's and Rochester's first meeting is constituted within the perfect fairy-tale setting, accordingly it takes place in the semiotic realm. ${ }^{35}$ The moon illuminates a cold twilight-scenery; just moments before their first actual encounter Jane contemplates about her imagination, which was nourished by the stories of her childhood that Bessie, the maid, used to tell her:

In those days I was young, and all sorts of fancies bright and dark tenanted my mind: the memories of nursery stories were there amongst other rubbish; and when they recurred, maturing youth added to them a vigour and vividness beyond what childhood could give. As this horse approached, and as I watched for it to appear through the dusk, I remembered certain of Bessie's tales, which figured a North of England spirit, called a "Gytrash;" which, in the form of a horse, mule, or large dog, haunted solitary ways, and sometimes came upon belated travellers, as this horse was now coming upon me. (98)

Through this paragraph, Brontë not only places emphasises on that Jane is already in the semiotic realm but she also demonstrates the willingness of her protagonist to leave the real world behind and to decent into a realm of romantic love. It also constitutes Rochester within the context of demonised and animalised male sexuality. As soon as Rochester appears, he lures Jane into the interior world of dreams, desires and passions:

35 For a further discussion of fairy-tale elements in Jane Eyre see, among others: Sandra Gilbert and Susan Gubar, Huang Mei, and Helen Moglen. 
He had a dark face, with stern features and a heavy brow; his eyes and gathered eyebrows looked ireful and thwarted just now ... I felt no fear of him, and but little shyness. Had he been a handsome, heroic-looking gentleman, I should not have dared to stand thus questioning him against his will, and offering my services unasked ...

If even this stranger had smiled and been good-humoured to me when I addressed him; if he had put off my offer of assistance gaily and with thanks, I would have gone on my way and not felt any vocation to renew inquiries: but the frown, the roughness of the traveller, set me at my ease. (99-100)

As Cho notes, Rochester has an "unconventional look" that contains a "kind of proud detachment and passionate energy with which she feels instinctively comfortable and familiar" (105). Cho comments that Jane's description of Rochester's physicality is an anesthetization of his masculinity:

I had hardly ever seen a handsome youth; never in my life spoke to one. I had a theoretical reverence and homage for beauty, elegance, gallantry, fascination; but had I met those qualities incarnated in masculine shape, I should have known instinctively that they neither had nor could have sympathy with anything in me, and should have shunned them as one would fire, lightning, or anything else that is bright but antipathetic. (99)

By pointing out his physical irregularities of an "un-heroic looking, middle-aged dark man" and depicting his appearance as contrary to "handsome youth[s]', it is obvious that Jane is fascinated mostly with his "lack of beauty" (105). By constituting him as a "charismatic" and not "beautiful" man, Brontë gives an entirely new definition of masculinity. Rochester, the embodiment of this new type of masculinity, strikes Jane "with such an impressive anomalous charisma as to leave an audible mark on her "gallery of memory" in an unprecedented way" (Cho 105):

The new face, too, was like a new picture introduced to the gallery of memory; and it was dissimilar to all the others hanging there; firstly, because it was masculine; and secondly, because it was dark, strong and stern. (101)

Brontë portrays Rochester as man who is aware of his shortcomings and who is torn between admitting it and trying to uphold a masquerade of masculinity. Neither Jane, nor Rochester are described as attractive in a conventional way, this "lack" of attractiveness prepares the ground for their shared appeal. Jane apparently falls under the Byronic spell, although she tries to renounce the romantic encounter as something unimportant - "[t]he incident had occurred and was gone for me; it was an incident of no moment, no romance, no interest in a sense" (101) - she cannot stop thinking about him and their meeting, and she even imagines, or hopes, to hear his horse again. 
Rochester enters the novel in a mythical light, but the illusion of masterful and powerful masculinity is undermined instantly when he falls from his horse to the ground and is unable to mount it again. This first depiction of him demonstrates that he is aware of his insufficiency, as he is unable to maintain the fantasy of his authoritative masculinity. He needs to lean on Jane physically to remount his horse. Contrary to the original Byronic hero, who chooses isolation and prefers to go alone through life to repent his sins, Rochester instantly recognises his dependency on Jane overtly (Hendershot 182). The first hint to a wholly transformed interpretation of the Byronic concept has thus been given.

Jane appears not as the typical damsel in distress but, on the contrary, as his rescuer. She insists upon helping this fallen stranger before she goes on her way. Moglen points out that from the first moment on, Rochester belongs to Jane's interior (semiotic) world, he is her "object of need", "cause of anxiety" and Jane's answer to her "restlessness which disappears with his presence" (118). Returning to Thornfield Jane discovers that the stranger turns out to be her master, $\mathrm{Mr}$ Rochester. The next day he summons her to take tea with him; Jane is redeemed quickly from her initial shyness towards him because of his impatient and slightly arrogant manner "I sat down quite disembarrassed. A reception of finished politeness would probably have confused me [...] A descent quietness, under the freak of manner gave me advantage" (105). Furthermore, Rochester also values Jane's unconventional honesty and frankness, which he considers to be part of her charm "You puzzled me [...] it would please me now [...] to learn more about you." (117). Her frankness attracts him:

"You examine me, Miss Eyre," said he: "do you think me handsome?"

I should, if I had deliberated, have replied to this question by something conventionally vague and polite; but the answer somehow slipped from my tongue before I was aware: - "No, sir." (115)

Thus, their shared unconventionality is the very essence of their attraction for each other.

An emphasis on the circumstance that the Thornfield episode is situated within the realm of the semiotic is given by several hints to the dream world of fairytales. Rochester's comments towards Jane link her instantly to the romantic world of fairy-tale fancies:

"No wonder you have rather the look of another world. I marvelled where you had got that sort of face. When you came on me in Hay Lane last night, I thought unaccountably of fairy tales, and had half a mind to demand whether you had bewitched my horse; I am not sure yet”. (107)

Moreover, it seems that he prefers to perceive her as something "otherworldly", as Moglen has argued, since he insisted upon it by continually linking her to the 
realm of fairytales by calling her "nonnette" (115), "elf" (215), "elfish" (229), "fairy" (235), his "good genii" (113). Jane's "Otherness" draws him to her.

Gilbert and Gubar argue that Jane falls in love with Rochester "not because he is her master but in spite of the fact that he is, not because he is princely in manner, but because, being in some sense her equal, he is the only qualified critic of her art and soul" (266). Rochester, in turn, needs her; when Bertha sets his bed on fire Jane rescues him; when Bertha attacks her brother Richard Mason, he entrusts him to Jane's care so that he can get the doctor. The fact that Rochester is repeatedly rescued by Jane creates their sense of equality that becomes most apparent when Jane is the only one who is not tricked by Rochester's masquerade as an old gypsy woman in the course of his party entertainment, but recognises the man behind the pretence.

Rochester's Byronic character is further accentuated by the narration of his past in which he embraces this definition of himself:

"I was your equal at eighteen - quite your equal. Nature meant me to be, on the whole, a good man, Miss Eyre, one of the better end, and you see I am not so ... Then, take my word for it, I am not a villain; you are not to suppose that - not to attribute to me any such bad eminence; but, owing, I verily believe, rather to circumstances than to my natural bent; I am a trite, common-place sinner, hackneyed in all the poor, petty dissipations, with which the rich and worthless try to put on life ... You would say, I should have been superior to circumstances; so I should - so I should; but you see I was not. When fate wronged me, I had not the wisdom to remain cool; I turned desperate; then I degenerated. Now, when any vicious simpleton excites my disgust by his paltry ribaldry, I cannot flatter myself that I am better than he; I am forced to confess that he an I are on a level. I wish I had stood firm - God knows I do! Dread remorse when you are tempted to err, Miss Eyre; remorse is the poison of life." (119-120)

He combines all of the main Byronic characteristics; although he confesses that he is a sinner, he claims not to be villain; fate alone is to be blame for his downfall: "I started, or rather (for, like other defaulters, I like to lay half the blame on ill fortune and adverse circumstances) was thrust on to a wrong tack ..." (119). As Moglen notes, he was "made desperate", "degenerated" through "the misery of an enforced marriage [to Bertha Mason, who he was forced to marry by his father because of her dowry]" (118). After the death of his father and elder brother, he still has to suffer from the consequences of their pressure to marry for money; isolated from society by his mad wife he flees to the continent and seeks pleasure, repenting his choices incessantly. When Jane asks him if he could not be cured from his current state by repentance, he answers:

"It is not a cure. Reformation may be its cure; and I could reform - I have strength yet for that - if - but where is the use of thinking of it, hampered, 
burdened, cursed as I am? Besides, since happiness is irrevocably denied to me, I have a right to get pleasure out of life; and I will get it, cost what it may." (120)

Rochester sees himself as the victim of unfortunate circumstances. He embraces the role of a rebel, by refusing to follow symbolic orders and flouts society's laws. ${ }^{36}$ He willingly ignores divine laws, such as monogamy, and tries to create his own moral commandment; he wants to make Jane his wife even though he is still married to Bertha.

Furthermore, his appearance also meets all the requirements of a true Byronic hero. Jane mentions his 'dark face', 'heavy features' and 'dark brows', which are all physical Byronic characteristics. Moreover, there is Bertha, his dark secret, his mad wife whom he has locked up on the third floor and tries to hide from society. As Millgate notes:

Rochester behaves quite deliberately and self-consciously like a Byronic hero, taking up dramatic poses, singing Corsair songs, acting arbitrarily and inscrutably; he talks of his past in Childe Harold's terms; he delights in dressing up and playing exotic roles. When such a figure is presented through the still more naively Romantic imagination of the eighteen-year-old Jane Eyre the coloration becomes positively violent. (318)

Accordingly, Jane fully succumbs to the Byronic hypnotic fascination.

Repeatedly, Rochester is connected to fire. He often sits in front of the hearth and smokes, and Jane tells the reader that "Mr Rochester would like to see a cheerful hearth when he came in" (243). Lodge points out that this element "is generally associated with the inner life of passion and sensibility" (131). In addition, Jane regularly compares him with fire itself, she mentions that "a strange fire was in his look," (133) that he "receive[d] the light of the fire on his granite-hewn features, an in his great, dark eyes," (115) and she hopes that she will not be "exiled from the sunshine of his presence" (216). Accordingly, fire is connected to both domestic idyll as well as to Byronic passion. Throughout her stay at Thornfield, Jane is confronted with the dangers of fire, literally and metaphorically. She soon sees the essential necessity to keep it under control; otherwise, she will be at risk to be burned by it, as the Byronic hero's capacity of passion makes it impossible for her to resist him.

\subsection{The Escape from the Byronic Power}

In a moment of despair, when she fears losing Rochester to another woman, Jane strips away all disguises and lets her passion free:

36 The flouting of authoritative laws is a Byronic characteristic that can be found particularly in Byron's protagonists Lara, Conrad and Cain. 
"Do you think, because I am poor, obscure, plain, and little, I am soulless and heartless? You think wrong! - I have as much soul as you,- and full as much heart! [...] I am not talking to you through the medium of custom, conventionalities, nor even of mortal flesh - it is my spirit that addresses your spirit; just if both had passed through the grave, and we stood at God's feet as equal, - as we are!"

“As we are!" repeated Mr Rochester. (222)

Rochester replies likewise by throwing away all pretences and confesses his love for her. The rhetoric of equality that is developed is based rather on a spiritual basis than a sexual one. Whereas he tried through his first marriage to comply with the symbolic and to gain status and money, his behaviour now suggests that this second marriage attempt is instructed by the semiotic and is based on love, a love which might redeem him from his inner pain.

Soon after his affirmation of equality however, his talk changes into the rhetoric of enslavement. In his intention of loading Jane with all of his family jewels and other treasuries, Lambert sees a metaphor for a "threatened submergence of Jane's identity in his" (111). His behaviour suggests that Jane cannot become his equal, and what formerly drew him to her, her frankness and independent spirit, he now tries to oppress by treating her as his property.

"I will myself put the diamond chain round your neck, and the circlet on your forehead, - which it will become: for nature, at least, has stamped her patent of nobility on his brow, Jane; and I will clasp the bracelets on these fine wrists, and load the fairy-like fingers with rings [...] I will make the world acknowledge you as a beauty too." (227)

But Jane vehemently denounces this new behaviour of his, of him trying to turn her into his possession by referring to his former affair: "Do you remember what you said of Céline Varens? - of the diamonds, the cashmeres you gave her? I will not be your English Céline Varens." (237). She insists on being and staying herself; plain Jane, the governess (237), however, she comes dangerously close to losing her own identity and integrity.

As Maynard points out, Rochester's sexuality is of a "direct and responsive nature" (110) which Jane has difficulties to resist. It becomes more and more overwhelming and Jane struggles to keep him at a distance. His Byronic character emerges once again after the failed marriage ceremony when he glares at the battlements of Thornfield and declares that he will seize happiness even if it means to write his own law. His Byronic character however, does not define his ultimate nature but provides a colour and excitement to his personality. His Byronic overreaching derives not from a need to carry a bleeding conscience, but from an intense need to have a fulfilled relationship with Jane. All of his former sins derive from sexual needs; the novel shows his weakness and vulnerability, he is sexually 
active and emotionally needy. However, with Jane he sees his chance for true love and happiness.

Chase comments that Rochester obviously serves as "Charlotte's symbolic embodiment of the masculine élan" (107). Jane's feelings for Rochester are situated always in conflict with each other, he "draws her to him with a strange fascination" but she is simultaneously "repelled by his animalism and demonism" (107). Chase proceeds by noting that she is torn between her desire to submit herself to him and the knowledge that she cannot do so. Jane is captivated by the gentleness and passion in his every trait, ranging from his masculine appearance, to the mysteriousness of his self-proclaimed guilt to his many female conquests. However, I disagree with Chase when he states that Jane flees because she could not "endure the intensity of his passions" and that she only sees two options of behaviour in this situation: "meek submission" or a "flirtatious, gently sadistic skirmishing designed to keep the love at bay" (107). Chase clearly seems to forget the fact that Jane decides to return to Rochester even before she has heard of Bertha's death and Rochester's freedom. Accordingly, she is not scared by his passion for her, but of her passion for him, since she began to lose herself in the pure semiotic. It is not her fear of Rochester's sexuality, or the limited options of behaviour she can choose from, as Chase argues, but her recognition that she is not able to keep a balance between the symbolic and semiotic that induces her to leave him eventually. In the midst of all this, as Gérin notes, Jane is still able to break free from the Byronic enchantment, from "the voice that has lulled all her senses" (18):

My future husband was becoming to me my whole world, and more than the world - almost my hope of heaven. He stood between my every thought of religion, as an eclipse intervenes between man and broad sun. I could not, in those days, see God for his creature, of whom I had made an idol. (241)

Rochester catalyzes Jane's passions and desires to such an extent that she can no longer think clearly, and is at risk to surrender her whole identity to him.

Mei argues that the failed marriage attempt can be seen as a turning point where Jane leaves the realm of the fairy tale and is for the first time at Thornfield fully driven by reason (168-170). When Rochester tries to convince her that she should stay as his mistress, since she has no one else who could care for her, Jane comes close to giving in, but in the end she finds the power to resist him. Nevertheless, after a severe inward struggle, instead of finding a balance between the symbolic and semiotic, she chooses the symbolic:

This was true; and while he spoke my very conscience and reason turned traitors against me, and charged me with crime in resisting him. They spoke almost as loud as feeling, and that clamored wildly. "Oh, comply!" it said. "Think of his misery, think of his danger, look at his state when left alone; 
remember his headlong nature, consider the recklessness following despair; soothe him, save him, love him, tell him you love him and will be his. Who in the world cares for you? Or who will be injured by what you do?"

Still indomitable was the reply, "I care for myself. The more solitary, the more friendless, the more unsustained, I am, the more I will respect myself. I will keep the law given by God, sanctioned by man. I will hold to the principles received by men when I was sane, and not mad - as I am now. Laws and principles are not for the times when there is no temptation; they are for such moments as this, when body and soul rise in mutiny against their rigor; stringent are they; inviolate they shall be. If at my individual convenience I might break them, what would be their worth? They have a worth, so I have always believed; and if I cannot believe it now, it is because I am insane, quite insane, with my veins running fire, and my heart beating faster than I can count its throbs. Preconceived opinions, foregone determinations, are all I have at this hour to stand by; there I plant my foot." (279)

When Rochester recognises Jane's strength as a power that he cannot conquer, he loses himself momentarily and tries to seize her with violence. The Byronic hero has finally met his match in her spirit: "It is you, spirit, with will and energy, and virtue and purity that I want; not alone your brittle frame" (280). However, staying with Rochester would represent the abandonment of principle for the consummation of passion, so she decides to leave.

Although Rochester tries to persuade her to flout every symbolic law, Jane resists him by declaring her faith in virtue as her only principle for conduct and asserting her independence once and for all. However, it takes all her strength to free herself from the Byronic enchantment:

I felt an inward power - a sense of influence - which supported me (266)

I was experiencing an ordeal; a hand of fiery iron grasped my vitals. Terrible moment; full of struggle, blackness, burning! Not a human being that ever lived could wish to be loved better than I was loved; and him who thus loved me I absolutely worshipped; and I must renounce love and idol. One drear word comprised my intolerable duty - "Depart!" (278)

Gérin points out that Jane's "greatness of conduct does not derive from virtue, but from the degree of her infatuation, from her susceptibility to temptation", the sense of a "higher morality" which is presented here is "shown as a quality of the mind, and not as an observance of the law" (18). Nevertheless, opposing to the other Byronic heroes (Glenarvon and Levison), Rochester's Byronic brooding does not lead to a triumphant seduction of the heroine. On the contrary, after Jane leaves him Rochester is left alone and cannot escape pondering on his mistakes. For now, he fails to make her into the wife he has "sought for twenty years, 
and never before encountered" (192) and is left with the knowledge of his errors and failure in a true Byronic manner.

\subsection{The Last Confrontation}

Jane suffers in running away from Rochester; nevertheless, it is a necessary act to escape the purely semiotic. Before she can achieve a balance of the two orders however, she is once again confronted with the symbolic in the form of her cousin St. John Rivers.

St. John Rivers is the embodiment of sexual and sensual renunciation, and thus an opposing extreme to Rochester. Even physically, there is a contrast to be found; where Rochester is depicted as the dark Byronic hero, St. John is presented as a fair avenging angel. His total repression of sexuality seems to have transformed him into something dangerous and harmful. Like Bertha, he has indications of madness, but where Bertha's madness is connected to fiery passion, his madness derives from cold repressed desires. Like Helen's inner fire, St. John's repressed passions are self-consuming. Through him, Jane moves once again into a layer of the novel that is social and moral, rather than personally and sexually characterised but demonstrates the danger of repressed emotions. This time however, not female but male sexuality is repressed through a self-imposed renunciation of desire.

The contrast of Rochester and St. John lies not only in their physical appearance but also in their characters, which is demonstrated in their behaviour towards Jane. When St. John asks Jane to marry him, she thinks: "To me, he was in reality become no longer flesh, but marble. His eye was a cold bright, blue gem; his tongue, a speaking instrument - nothing more" (361). With inhuman strength, he directs his will towards self-sacrifice and tries to pressure Jane into the same direction. Even Jane's relationship to St. John is contrasted to Rochester, whereas the latter acknowledges Jane's independence and passion, St. John, on the other hand, tries to oppress it. However, like Rochester, he exerts an inexplicable power over Jane that she finds hard to resist:

By degrees, he acquired a certain influence over me that took away my liberty of mind; his praise and notice were more restraining than his indifferences. I could no longer talk or laugh freely when he was by, because a tiresomely importunate instinct reminded me that vivacity (at least in me) was distasteful to him. I was so fully aware that only serious moods and occupations were acceptable, that in his presence every effort to sustain or follow any other became vain; I fell under a freezing spell. When he said "Go," I went; "Come," I came; "Do this," I did it. But I did not love my servitude; I wished, many a time, he had continued to neglect me." (350) 
St. John makes her fear that her "vivacity is disdainful." Once again, Jane is trapped in the symbolic and St. John's influence over her even progresses. She is unable to fight and about to surrender her will and spirit to him. She is well aware that she is constantly torn between submission and revolt in his presence:

I know no medium; I never in my life have known any medium in my dealings with positive hard characters, antagonists to my own; between absolute submission and determined revolt. I have always faithfully observed the one, up to the very moment of bursting, sometimes with volcanic vehemence, into the other; and as neither present circumstances warranted, nor my present mood inclined me to munity, I observed carful obedience to St. John's directions (352).

Jane recognises and acknowledges the interdependency between the symbolic and the semiotic in herself, between self-oblivion and self-assertion, and although she usually breaks away when one of these forces becomes too powerful, she knows that she cannot defend herself against St. John Rivers:

As for me, I daily wished more to please him; but to do so, I felt daily more and more that I must disown half my nature; stifle half my faculties, wrest my taste from their original bent, force myself to the adoption of pursuits for which I had no natural vocation. He wanted to train me to an elevation I could never reach; it racked me hourly to aspire to the standard he uplifted. (351)

St. John is preparing to go to India as a missionary and he wants Jane to go with him as his wife, although he completely rejects the perception of her as a woman. Moglen comments that "he wants her to deny her sexuality (feeling/body) to subordinate that which is most vital in her to his own spiritual quest. St. John uses his predestinarian religious belief to make her to obey him, he argues that submitting to him would mean election; a refusal would make her a "castaway"' (364). He further argues: "God and nature intended you for a missionary's wife. It is not personal but mental endowments they have given you; you are formed for labor, not for love. A missionary's wife you must - shall be. You shall be mine; I claim you" (354). She rejects his judgement: "I am not fit for it; I have no vocation" (354). When she offers to accompany him as a sister, he refuses: "I, too, do not want a sister; a sister might any day be taken from me. I want a wife; the sole helpmeet I can influence efficiently in life, and retain absolutely till death" (357). He wants the power to completely control her as his wife. He wants to make her his property and turn her into an object. Jane recognises that being in a loveless marriage, being with St. John would be her death: "if I were to marry you, you would kill me. You are killing me now" (363).

She tries to resist the assumption that he is an agent of God but the temptation to give in is strong: 
I was tempted to cease struggling with him - to rush down the torrent of his will into the gulf of his existence, and there lose my self. I was almost as hard beset by him now as I had been once before, in a different way, by another. I was a fool both ties. To have yielded then would have been an error of principle; to have yielded now would have been an error of judgment. (368)

Nevertheless, in the end, she can resist him and the confrontation ends with a sharp attack on St. John's hypocrisy, arrogance and idea of love:

"I scorn your idea of love," I could not help saying, as I rose up and stood before him, leaning my back against the rock. "I scorn the counterfeit sentiment you offer; yes, St. John, and I scorn you when you offer it.” (359)

Jane finally recognises that St. John's heroic image is nothing more than a masquerade; he is merely a fallible, imperfect human being. Moglen argues that Jane was under the influence of St. John's sexual power but that her final refusal "yields awareness and self-discovery instead of dread annihilation" (139). Furthermore:

Much of the dangerous appeal of Rochester's sexuality had derived from a similar charisma power (a charisma not completely lacking, as masculine force, even in Brocklehurst and John Reed). That appeal is experienced by here fully - and finally, absolutely rejected. (139)

\subsection{An Independent Woman}

When the dangerous appeal of sexual power is finally broken, Jane can withstand and explore it without running into the danger of losing herself. She consciously chooses the semiotic, she chooses Rochester. The inner struggle between the symbolic and semiotic is ended and she once again can enter the semiotic, but this time with a new strength and on her own terms. Jane needed to resist the force of the symbolic power once again to be able to choose freely between the two orders. Rochester's call thus comes as a response of the need in herself for the semiotic: "I heard a voice somewhere cry, 'Jane! Jane! Jane!' noting more ... it spoke in pain and in woe - wildly, eerily, urgently" (369). From this moment on the temptation which St. John constitutes is forgotten and Jane hurries back to Thornfield to be with Rochester, even though she has not yet learned of Bertha's death.

When she arrives at Thornfield she finds it a ruin. She is told that Bertha set the mansion on fire and although Rochester tried to rescue her, died from a jump of the roof. After the destruction of Thornfield, Rochester has retreated to Ferndean, where Jane finds him maimed and blinded by the fire. The Byronic hero is broken and does no longer exist. Rochester's threatening sexual power is 
gone; he is now desexualised but redeemed through Jane's return by love. Whereas he was before a rebel, he is now Christianised and believes in the divine law. A true fairy-tale ending is now possible. When Rochester is courting Jane, she tells him that when they are married

"for a little while you will perhaps be as you are now, - a very little while; and then you will turn cool; and then you will be capricious; and then you will be stern, and I shall have much ado to please you: but when you get well used to me, you will perhaps like me again, - like me, I say, not love me. I suppose your love will effervesce in six months, or less" (228).

This is a reasonable and realistic conclusion when considering a union of dominance and submissiveness: the male, who is more powerful, will eventually tire of the weaker female. She will then be unable to satisfy him. The reversal of these gender roles is brought about by the decline of Rochester's dominant position, through the breaking of his Byronic power. In the end they are equals, Rochester now depends on Jane and she realises that "I love you better now, when I can really be useful to you, than I did in your state of proud independence, when you disdained every part but that of the giver and protector" (392). Rochester's reduction of power is precipitated by Brontë's realisation that, within the constraints of a common constellation of the male as a subject and the female as an object, a happy ending is impossible. Towards the end of the novel, in the face of traumatic events it becomes apparent that Jane and Rochester depend on each other, recognise their equality. When Rochester touches Jane now it is not motivated by sexual desire but because he perceives her as his "prop and guide" (395).

She returns to Rochester as a free individual, constrained neither by the symbolic or semiotic, but as her own woman who chooses for herself. She is completely independent and in every way his equal, if not even his superior. Thus, she announces to the reader "Reader, I married him" (395) as a sign of her emancipation. Now that the war of the orders within her has ended, she eventually embraces "woman's work". She reminds the reader that domesticity in itself is not the culprit, she has been given the opportunity to put higher duties of life before passionate love, but decided against it.

\subsection{Conclusion}

Jane is one of the first heroines in nineteenth-century literature who does not pretend to be content with her restricted role as a woman. She is torn perpetually between reason and emotion, the symbolic and semiotic, and in her search for equality and independence; she wants to find a means of balancing the dictates of both. By the examples of Helen, whose desire for death demonstrates how a total compliance with the symbolic results in violence against the self, and Bertha, 
whose fate raises the awareness of an amalgamation between sexual suppression and its consequence: madness, Jane is warned to comply solely with one order.

The Byronic hero catalyzes Jane's feminine desire for the male subject. Brontë knew that there could be no happy-ending where a Byronic hero was concerned, since he is too powerful and oppressive a character. Consequently, the hero needs to be broken, stripped of his power and crippled, in order to ensure a relationship of equality between Rochester and Jane. In the end, Rochester has to atone for his sins, which results in the loss of the role of the dominant male leader. Nevertheless, through his love for Jane, he is able to admit his dependence on her; he has discarded every sign of self-righteousness and pride. One of the first authors who actually placed the hero within reach of redemptive love is Charlotte Brontë, whose Mr Rochester could be saved by Jane Eyre. He accepts the existence of a higher power and loses his threatening power, with which he has put Jane's identity at risk. His blindness, from which he will eventually recover, is a symbolic immersion of the male hero in a feminine experience; men must learn how it feels to be helpless and to be forced into dependency.

Jane has eventually found a way to balance the two orders, an unconventional circumstance which forces her to live withdrawn from society at Ferndean in the forest, since society would not accept such an arrangement.

\section{Ellen Wood's East Lynne}

\subsection{Ellen Wood: Firm Moralist or Cultural Critic}

East Lynne by Ellen Wood was serialised from 1861 to 1862 in William Harrison Ainsworth's New Monthly Magazine and became an instant hit. When it was reprinted in three-decker form, it became an immediate success. It is said to have been sold more than two and a half million times by the end of the century and has been translated into various languages (Jay xxxviii). However, in the twentieth century it fell out of print and became forgotten. It underwent what Light calls "cultural squint" a result of the literary institution's "obsession with [...] elites" (11).

The novel depicts unequal power relations between men and women by focusing on Lady Isabel Vane, who after the death of her father, Lord Mount Severn, marries the country lawyer Archibald Carlyle. Carlyle purchases her father's estate East Lynne. Isabel marries Carlyle out of necessity as her father died without making any provisions for his daughter. Her love for Sir Francis Levison leads her to elope with him to Franc. When he abandons her she is once again homeless and penniless. Disguised as Mme Vine she returns home to become a governess to her own children. The total dependency of women on men and the demand to put institutionalised and before passionate love is clearly criticised. 
Critics have argued that East Lynne's powerful attraction to Victorian readers lay not only in the subject matter but in that she reinvented the "conventions of domestic realism but also employs seemingly anti-realistic devices roofed in the Gothic in order to convey a darker vision of the home" (Introduction: Ellen Wood, Writer 151). Thus, the sacred home suddenly became a place of secrets and lies. The consequence of placing the home within a Gothic setting "led to Wood rather than Wilkie Collins - being labelled as "the originator and chief of the sensational school" by commentators" (Introduction: Ellen Wood, Writer 151). Sensational novels describe a literary genre that was popular in the 1860s and 1870s. They have been characterized as "novels with a secret".

This genre was regarded as a completely new form of fiction by contemporary reviewers of the mid-Victorian literary scene that replaced the stereotypical form of the the domestic novel, the only proper one for female readers, from its position of dominance as it indulged the public craving for scandal. In this new novelistic mode, the heroines of the complicated plots about crime, bigamy, or adultery evolve in a passionate, devious and dangerous manner. The novels evoke the Victorian public's lust for scandal as they situated murders, mysteries, and social improprieties within respectable middle class or aristocratic homes. The sanctity of the family, as well as the stability of middle-class mores, was put into question, their narratives parallelizing the daily newspapers' contents of the newly instituted divorce courts. Furthermore, the stability of individual identity was challenged frequently by showing that a person's outer appearance and status could not be taken as proof of personality and motives.

To express both feminine desire and fears that were otherwise ignored by contemporary discourses, Wood used the supernatural which found a way into the home. Jaquet notes that the "non-realistic mode of the supernatural becomes a strategic choice for female authors in order to represent the often marginalized experiences of Victorian women" (245). She continues by pointing out that Wood "illuminates the operations of the supernatural ... as a form of investigation and redefinition of the domestic sphere" (245). Accordingly, the supernatural in Wood that is demonstrated, among others, through uncanny dreams and shadows, is connected to the domestic sphere, thus the author is able to present the various and different experiences of women. Dickerson argues that "the supernatural tale allows for play, speculation, investigation and redefinition" and is thus "presenting an important avenue for female writers to comment on their society" (148). The new motif of the family threatened from the outside, in this case by an aristocratic, dangerous male seducer, evoked both indignation and curiosity.

Many established critics thought that the primary function of art was to "elevate or purify" and as sensational novels did no such thing, they responded with moral outrage and dismay at the public approval of this new genre. Sensational novels exhibit a variety of characteristics of genres, such as melodrama, romance, gothic, realism, and Newgate fiction and thus can be seen as generic hybrids that 
are related to both sensational journalism and melodramatic theatre. They are mainly described as being "plot-driven" in contrast to "character driven". Therefore, they are often regarded as inferior to Victorian realism, both artistically and morally and as a sub-genre that is peculiarly feminine and mostly written by women to women (Harrison and Richard xii). Mitchell comments that sensational novels were and still are easily dismissed by critics as they lack reality. However, by dismissing them, she warns, one does not understand "the function of women's recreational reading", as "these books do not provide pictures of the contemporary scene" they "can be read to indicate the way women felt about the society they lived in" ("Sentiment and Suffering" 31).

Nevertheless, recent studies have shown that sensational novels were devoured by men and women alike. Mitchell explains East Lynne's immense success in that "readers were tired of the inane and impossible goodness in heroines. Really interesting women - and women worth writing a whole book about - had sexual experiences" (The Fallen Angel 74). The first novel to be critically dubbed "sensational" was Wood's East Lynne (1861). It eventually started a new literary trend, whose main exponents also included Wilkie Collins (The Woman in White, 1859; The Moonstone, 1868), Charles Reade (The Cloister and the Hearth, 1861) and Mary Elizabeth Braddon (Lady Audley's Secret, 1862). Though judged as heavily sentimental and crudely melodramatic, Wood's novel in particular enjoyed immense popularity due to the detailed and quite accurate representation of the worldview of its middle-class audience.

Another dominant discourse of East Lynne, apart from the woman question, is a panorama discussion of society which supposedly added to the novel's appeal for the middle-class reader. Wagner notes that East Lynne "forms a charting of the social and cultural competition between gentility in decline and [the middle class]", thus, it contains "increasingly complex representations of the aristocracy and landed gentry" and that Wood "seek[s] to negotiate shifts in the social construction of gentility as a cultural enterprise in the nineteenth century" (200). In other words, Wood contrasts the aristocratic and the middle class to demonstrate the moral superiority of the latter. The aristocracy in East Lynne is presented in a bad light; Lady Isabel's whole family, for example, has been nearly erased because of indulgence, decadence and wastefulness. Through her marriage with Carlyle, Isabel's transgression from one class into the other "symbolizes the failure of aristocracy" (A. Kaplan 45) and depicts the middle class as a new representative of morality and the law. Wynne argues that Wood demonstrates the middle-class's superiority by their way of obtaining prestige, namely through "discipline, determination, and disarmingly genial manners [they] inherit the power, property, and status of a class group she publicly emulates, but secretly envies and despises" (68). 


\subsubsection{The Byronic Hero's Transformation}

In the Victorian age, a new concept of Byronism was invented, as the Victorians applied their moral code to him. As a result, several interpretations of this hero and different emphasis on topics regarding the Byronic hero evolved. Accordingly, Carlyle used the concept in his work to focus on class issues, Brontë to focus on gender roles, Tennyson to discuss popularity and Bulwer-Lytton, Disraeli, and Wild to focus on sexuality (Elfenbein 10). Elfenbein notes that in the 1840s the romantic had to give way to the realistic novel, as Byron and his literary persona were connected to Romanticism, the rise of realism simultaneously entailed a rejection of the Byronic hero (146). Thus, a dualism of the Byronic perception evolved; although he did not lose his appeal to the reading audience, novelists (like Eliot and Wood) dealt with him more critically. His overtly sexual attractiveness becomes a reason of rejection, as morality and proper behaviour develop into conventions that were to be followed strictly. Accordingly, Wood presents the Byronic hero in form of Sir Francis Levison as an Iago-like character. He is a heartless, evil seducer; a vilified dandy, whose force of meaningless malevolence destroys lives. He is stripped of all "attractive" Byronic attributes, like mysteriousness, broodiness and obvious remorse; instead, he embodies negative, aristocratic characteristics, such as arrogance, indifference and extravagance.

\subsubsection{Differences of Opinion in Wood Scholarship}

Wood as a writer of sensation novels is perceived to be one of the most conservative and domestic writers. It has been argued that the narrator, who is strongly associated with Wood herself, favours the new middle-class family and thus serves the symbolic as she supports with patriarchal ideas through her harsh critique of female sexual desire and passion. ${ }^{37}$ A. Kaplan argues that "she [the narrator] can vividly appreciate the attractions of desire, but self-righteously sets itself against it in "lectures" to the reader" (46). She adds that "like Wood herself, the narrator cannot think outside of the discourse available within the fictive world and thus cannot conceive a world in which female desire would not destabilize the entire system" (46). Wynne comments that East Lynne is a "product of a conservative, rather old fashioned magazine" and that it "promoted views which blended comfortably with the magazine's house style" (64). However, she also points out that the only source of Wood's life is "her dutiful son's unsatisfactory biography" that "obscures and mythologizes one of the most prolific writers of the Victorian Period" (65). The picture of Wood, which is presented by her son Charles in his Memorial of Mrs Henry Wood (1894), is that of a "conservative, passive, nervous and domestic" woman. The contrasting picture of Wood however, that emerges more

37 For such an interpretation of Wood's intention see A. Kaplan. 
and more, is that of a "self-promoting, hard-working writer and editor" (65). For more than twenty years, she was the editor of The Argosy magazine and produced almost 40 novels and more than 300 short stories and articles. This suggest that Wood was herself a more interesting woman than she has been given credit for. Her son presents her writing not as a kind of work but as a peaceful hobby of a flawless, moral woman writer and his account "overlooks some of the more complicated elements of Wood's writing career to assure readers that her femininity was never compromised by her fame" (Introduction: Ellen Wood 153). Her son obviously realised the importance of presenting his mother as a delicate woman, in order to disguise her "unfeminine" energy of management skills and literary aspirations.

Critics like Maunder judge East Lynne to be "a host of contemporary moral, social and scientific anxieties to the fore" and comment that the "moral contamination of the wife and mother gone mad with uncontrolled sexual longing" is severely punished, as Wood presents it as a "threat to the individual family unit and broader morality of the nation as a whole" (59). Nevertheless, critics like Showalter argue that Wood had a "powerful appeal to the female audience by subverting the traditions of feminine fiction to suit their own imaginative impulses, by expressing a wide range of suppressed female emotions, and by trapping and satisfying fantasies of protest and escape" ((1977) 158). Accordingly, the character of Wood-criticism is dualistic, as she is either depicted as a stern moralist or as "the emancipated daughter of Charlotte Brontë and a cultural critic" (Introduction: Ellen Wood, Writer 152).

\subsubsection{Feminist Criticism}

In the second half of the twentieth century, feminist criticism discovered a new interest in the novel, as it powerfully describes a maternal melodrama and is concerned with the restrictions imposed on women in order to become the perfect woman. Wynne comments that nowadays East Lynne is considered as "the archetypal woman's novel, its mixture of sentiment and sensation forming a model for later examples of popular romantic fiction" (61). She continues to argue that, "Wood's famous address to the reader as "Lady - wife - mother" is an exhortation to women to bear any burden in the cause of domestic unity and appears to establish East Lynne firmly as women's fiction" (61).

Feminist criticism has put its focus on Lady Isabel as exemplifying the "tensions and restrictions associated with Victorian codes of femininity" (67). However, feminist critics have mainly emphasised Isabel's role as a mother and read East Lynne as a maternal melodrama. Thus, A. Kaplan sees Isabel's story as a melodramatic warning against disproportionate feelings for her children. Cvetkovich also focuses on the melodramatic plot surrounding Isabel by describing East Lynne as a "drama of effects" that "transforms a narrative of female 
transgression into a lavish story about female suffering that seems to exceed any moral or didactic requirement that the heroine be punished for her sins" (98-99). Cvetkovich joins the group of critics who perceive Wood's excessive punishment for Isabel as a means to demonstrate her adultery and abandonment of her family as unpardonable. Wynne also argues that the "enjoyment for readers [lies] more in Barbara's triumph over Isabel rather than its capacity to generate tears" (67). Here she disagrees with Langbauer who perceives it to be a "weepy melodramatic" novel and comments that "all female characters cry hysterically throughout it" (227). All these feminist critics lay their focus on either Isabel's excessive maternal feelings, the appeal of the novel to female readers because of its melodramatic mood and the ability to 'generate tears' or on Isabel's excessive suffering as a warning for the female population to stay within their assigned sphere. What they fail to mention is what Showalter points to: that Wood "expressed female anger, frustration, and sexual energy more directly than had been done previously" (1999, 158).

Moreover, a closer reading of Wood's works suggests that her novels and East Lynne in particular, are concerned with the exposure (supposedly unconsciously, as has been argued) of the difficulties, economic and ideological, women had to endure. While excessive women are always severely punished in her works (usually through imprisonment or death) this is done in a way "which some critics have suggested smack "of rebellion against constraints of the respectable plot" (Introduction: Ellen Wood, Writer 151).

To read Wood's East Lynne as a pure condemnation of the fallen Isabel and thus a propagating of middle-class values is too simplistic a reading, as the novel is more complex than that. It is also possible to read the text as both a critique on the emotional restrictions imposed on women in the nineteenth century and the shortcomings of bourgeois masculinity. The Byronic hero, here stripped of any positive quality and presented as a pure seductive villain, acts again as a catalyst of desire that induces the heroine to flee the restrictions of the passionless, symbolic sphere.

\subsection{Lady Isabel: Propriety vs. Desire}

East Lynne differs in its structure from Glenarvon and Jane Eyre. Where in the latter two novels the heroines meet the Byronic hero and are confronted with the temptation to give in to the semiotic only after their lives within the symbolic has been presented, Lady Isabel encounters the Byronic hero right from the start. Thus, she is immediately torn between sexual desire and decorum, as she meets Sir Francis Levison only shortly after her very first meeting with Archibald Carlyle, a fact on which the narrator comments: 
Strange - strange that she should make the acquaintance of those two men in the same day, almost in the same hour: the two, of all the human race, who were to exercise so powerful an influence over her future life! (15)

Accordingly, she is confronted from the very beginning with the temptation of the semiotic but is still too firmly positioned within the symbolic to act on it.

In the first part of the novel, she is presented as the lucky, successful heroine, who is at the heart of love and domesticity. Carlyle meets Lady Isabel Vane for the first time when he visits her father, Lord Mount Severn, in order to enquire about the opportunity to buy his country estate East Lynne. His first impression of Lady Isabel is described as follows:

Who - what - was it? Mr Carlyle looked, not quite sure whether it was a human being: he almost thought it more like an angel.

A light, graceful, girlish form, a face of surpassing beauty, beauty that is rarely seen, save from the imagination of a painter, dark shining curls falling on her neck and shoulders smooth as a child's, fair delicate arms decorated with pearls, and a flowing dress of costly white lace. Altogether, the vision did indeed look to the lawyer as one from a fairer world than this ... Mr Carlyle had not deemed himself a particular admirer of woman's beauty, but the extraordinary loveliness of the young girl before him nearly took away his senses and his self-possession. (11)

Representing the perfect, delicate, fragile attributes of femininity, Isabel is already depicted as a dependant, childlike woman. She is the embodiment of the ideal notion of femininity. Immediately after her meeting with Mr Carlyle, she sets out to visit old Mrs Levison, where she is introduced to Captain Francis Levison. He is described as a "young and elegant man" (14). The narrator continues:

He was deemed handsome, with his clearly-cut features, his dark eyes, his raven hair, and his white teeth: but, to a keen observer, those features had not an attractive expression, and the dark eyes had a great knack of looking away while he spoke to you ...

Few men were so fascinating in manners (at times and seasons), in face, and in form, few men won so completely upon their hearer's ear, and few were so heartless in their heart of hearts. The world courted him, and society humoured him: for, though he was a graceless spendthrift, and it was known that he was, he was the presumptive heir to the old and rich Sir Peter Levison. (14-15)

While the outward characteristics, as the dark hair and eyes, and his masculine features are still depicted as attractive and mesmerising, the repugnance and dangerousness of this character is instantly established. Isabel cannot elude his charm. A. Kaplan comments that a Christian undertone is used to demonstrate her dilemma; thus, Isabel is linked to "the figure of Eve in the Garden of Eden and 
perused by 'snake' Levison" (35). This becomes apparent when Levison breaks her cross on her necklace that had been given to her by her mother. Her mother gave it to her as a talisman on her deathbed and told her to look at it when in "distress, or in need of counsel" (17). Not only can the breaking of the cross by Levison be seen as a premonition of things to come, but A. Kaplan argues that the "breaking signals Isabel's aloneness and vulnerability to the 'snake' Levison" and that he is "ready to step into the gap left by her mother's death" (36). Accordingly, she points out that "right from the start she experiences a merging sensation with Sir Levison" (36). The Byronic hero evokes unknown desires in Isabel and she succumbs to his charm completely, as the following paragraph demonstrates:

He spoke in a tone of thrilling gentleness, gratifying to the ear but dangerous to the heart. Lady Isabel glanced up, and caught his eyes fixed upon her with the deepest tenderness, a language hers had never yet encountered. A vivid blush rose to her cheek, her eyelids fell, and her timid words died away in silence. (19)

Levison is able to arouse sexual desires in her that she has never experienced with Carlyle. The difficulties to favour an institutionalised for a passionate love are thus anticipated.

\subsubsection{The Fading Angel in the House}

When Isabel is left homeless, penniless and dependant on relatives who do not want and dislike her, she marries Carlyle, as he is able to offer her a stable home that was once her own, East Lynne. Yet, when he proposes, Isabel is not sure if she can accept his offer:

It was a perplexing debate that Lady Isabel held with herself in the solitude of her cambers ... Isabel was little more than a child, and as a child she reasoned, looking neither far nor deep: the shallow, palpable aspect of affairs alone presenting itself to her view. That Mr Carlyle was not of rank equal to her own, she scarcely remembered: East Lynne seemed a very fair settlement in life, and in point of seize, beauty, and importance, it was superior to the home she was now in. She forgot that her position at East Lynne as Mr Carlyle's wife, would not be what it had been as Lord Mount Severn's daughter; she forgot that she would be tied to a quiet home, shut out from the great world, from the pomps and vanities to which she was born. She liked Mr Carlyle much, she liked to be with him, she experienced pleasure in conversing with him; in short, but for that ill-omened fancy which had 
crept over her, there would have been danger of falling in love with $\mathrm{Mr}$ Carlyle. $(120-121)^{38}$

Isabella muses:

"So far it looks favourable," mentally exclaimed poor Isabel, "but there is the other side of the question. It is only that I do not love Mr Carlyle, but I fear I do love, or very nearly love, Francis Levison. I wish he would ask me to be his wife! - oh that I had never seen him.” (121)

The difficulties to follow are all presented in these two paragraphs: Isabel's childlike character hinders her ability to perceive things more clearly. In a society where women are not supposed to act for themselves, she has never learned how to take care of herself. She has neither home nor friends to turn to, consequently, accepting Mr Carlyle's proposal would get her out of her dilemma. Although a quiet home suits her, she is not prepared for the eventual boredom, uselessness and powerlessness that awaits her at East Lynne. In addition, she does not love her husband but yearns for another man. With so many obstacles already in the way, Isabel is bound to fail.

Throughout her marriage with Carlyle, she remains a child-like woman, a passive angel and decorative object. In order to support her he invites his brusque half-sister Cornelia to live with them at East Lynne to help Isabel run the household. However, the strong-minded unmarried woman soon takes over. Consequently, Isabel is miserable, she is unable to defend herself against Cornelia's subtle abuses or tell her husband about it; she is homeless and powerless within her own home. At the first meeting of the two women, Cornelia's dominance and Isabel's helplessness is already established. After Isabel and Carlyle have arrived home from their honeymoon, and the two women have been introduced to each other, Isabel asks if she could have some tea but Cornelia denies it to her:

“Tea!" ejaculated Miss Corny. "So late as this! I don't know that they have boiling water. You'd never sleep a wink all night, ma'am, if you took tea at eleven o'clock."

"Oh - then never mind," replied Lady Isabel. "It is of no consequence. Do not let me give you trouble." ...

Meanwhile, Lady Isabel sat down and burst into tears and sobs. A chill had come over her: it did not seem like coming home to East Lynne. $\mathrm{Mr}$ Carlyle entered and witnessed the grief.

38 Although my focus does not lie on the class discourse, I have to point out that Isabel's shortcomings, which have been contrasted to Barbara Hare's abilities, and which are ascribed to her aristocratic ancestry, are enforced by middle-class notions. It is Carlyle, the middle-class lawyer, who is responsible for Isabel's inability to develop. Through his overprotective manner (letting his sister run his household), his inability to perceive Isabel's unhappiness, and his secretiveness which let to her elopement, he is responsible for her fall. 
"Isabel!" he uttered in amazement, as he hastened up to her. "My darling, what ails you?"

"I am tired, I think," she gently answered; "and coming into the house again made me think of papa. I should like to go to my rooms, Archibald, but I don't know which they are." (142)

Through her child-like character, Isabel is unable to voice her wishes; she feels her powerlessness and has no other means to express it than through tears.

Although she has been idyllically happy in the beginning of her marriage, Isabel regresses more and more into dependency, childlike behaviour, and idleness neither her character nor her abilities have the chance to develop, as she is treated like a naive girl. She feels hurt because her husband pays her less attention as soon as the honeymoon is over. It is her only wish to be with Carlyle but since he has to attend to his business he is gone most of the day. Mitchell suggests that Isabel thought it was a woman's business to maintain a perfect relationship with her husband, and as she is unable to do that, she perceives herself as a failure. This feeling of inferiority originates in Isabel's idea that "if she were a better woman, somehow, he would love her more" (The Fallen Angel 81). Furthermore, Mitchell argues that since their betrothal the "marriage and husband are the focus of her feelings of inferiority" and through her ultimate elopement "she strikes at [him] by using the weapon which is most effective in the battle of sexes" "Sentiment" 42). Isabel has nothing else to do than to wait for him; thus, she gets bored, listless and feels empty without him. Even though she is loved and cherished by him, she is not allowed to grow up. Mitchell points out that she "stands to him as a child to a parent" (The Fallen Angel, 80) as the marriage advances, the feeling of emptiness and a need to be loved becomes her normal condition. She spends her time with reading novels, and painfully bears Carlyle three children, which weakens her to such an extent that she becomes an invalid. Sick, faint, fragile and oppressed by her sister in law, Isabel slowly pines away in her own home. Accordingly, the suppression and repression of her desires and her inability to communicate her unrest to her husband, leads to an endless downward spiral, resulting in her fading away and would eventually have lead to her death, as angels were supposed be content no matter what.

In addition, she is tortured by an irrational and unfounded jealousy of her husband's friend Barbara Hare. As already mentioned, Barbara's brother Richard is involved in a murder case and the suspected murderer. Barbara, who is convinced of his innocence, turns to Carlyle for help. Isabel sees Barbara as a rival for his affections since she is actually is deeply in love with Carlyle. Isabel overhears a conversation between two servants, in which they discuss Barbara's love for Carlyle; she is convinced that he has never loved her:

[The overheard conversation] might not, indeed would not, have made so great an impression upon her had she been in strong health, but she was 
weak, feverish, in a state of partial delirium; and she hastily took up the idea that Archibald Carlyle had never loved her, that he admired her and made her his wife in his ambition, but that his heart had been given to Barbara Hare.

A pretty state of excitement she worked herself into as she lay there, jealousy and fever, ay, and love too, playing pranks with her brain ... her pallid cheeks were burning with a red hectic, and her eyes glistened with fever. (180)

Again, the state Isabel is kept in is clearly criticised by Wood. If the people around her had some confidence in her and her abilities, she would have the chance to grow up and would not work herself into such a fit. However, there is nothing else for her than to lie down, and as a result, her jealousy runs wild. A Kaplan points out the dilemma in which Lady Isabel is situated within the symbolic. While she completes Carlyle's world, she herself is quite incomplete. She is even deprived of the action and power of her domestic role. Thus, "she is left in a position of lack and as the object of the male gaze [Carlyle/Levison] and of the jealous female gaze [Barbara/Cornelia]" (38).

Isabel's doctor recommends that she should be send to France to recover, as he is concerned for her life. Isabel, who sees the sending away as a means for Carlyle to be with Barbara, is anxious to leave home and wishes to at least take her children with her, as she cannot stand the idea to be parted from them. Cornelia, however, denies her that wish. She makes her feel guilty about the expenses Carlyle had to spend, and since Isabel is already a high cost factor, she suggests Isabel should be content and stop being presumptuous. Thus, miserable, jealous, and lonely Isabel leaves for France, where she meets upon Sir Levison. A. Kaplan notes that Isabel's longing to take her children with her originates in a "fear of separation, individuation and emotional autonomy" which she is not used to. Consequently, Isabel's repressed desire for Levison quickly emerges again and he fills the emotional gap left by her isolation. Ann Kaplan continues to argue, "her desire forced itself upon her physically, in a way rare in fictional representations of female characters" since "the novel locates Isabel within the power relations of patriarchy, she cannot consciously accept herself as a desiring subject" (37). Consequently, her desire expresses itself through her body:

After an interval, there appeared another, a tall, handsome, gentlemanly man. Her eyes fell upon him; and - what caused it that caused every nerve in her frame to vibrate, every pulse to quicken? Whose form was it that was thus advancing, and changing the monotony of her mind into tumult? It was one of whom she was soon to find had never been entirely forgotten [Captain Levison]. (205) 
Through his presence and the attention he pays her, Isabel quickly recovers. She is well aware of her feelings for him. Even more, the Byronic power has such an effect on her that she starts to feel like a young and happy girl again:

She did not dare to analyse her feelings, but she was conscious that all the fresh emotions of her youth had come again. The blue sky seemed as of the sweetest sapphire, the green fields and the waving trees were of an emerald brightness, the perfume of the flowers was more fragrant than any perfume had yet seemed. She knew that the sky, that the grassy plains, the leafy trees, the brilliant flowers were but as they ever had been ... and she knew that the change, the sensation of ecstasy, was in her own heart. No wonder that she shrank from self-examination.

The change from listless languor to her present feelings brought the hue and contour of health to her face far sooner than anything else could have done. (209)

In case of Lady Isabel, the appearance of the Byronic hero does not only generate repressed sexual passion, which she does not feel for her husband, but it simultaneously seems to save her life. Where she did not improve under her husband's care, the mere presence of Sir Levison heals her.

For Isabel, Carlyle and Levison are representatives of the symbolic and semiotic; her compliance with the symbolic almost led to her death. Repressed desire, idleness, powerlessness, helplessness turn her into a mere shadow, a decorative object, a child-like woman. Her inability to withstand Cornelia's tyranny add to her fading away. Wood obviously uses Isabel as an example of what happens to women if they are too weak and incapable to defend themselves in an oppressive patriarchal system; they turn into shadowy victims. Thus, the encounter with the semiotic immediately revives Isabel's will to live. However, Isabel is not yet willing to give into the semiotic and to leave the symbolic; on the contrary, she tries to fight it:

She knew - and she could not stifle the knowledge, however she might wish to do so - that it was not the place or the sea-air which had renovated her heart and her countenance. But she clasped her husband's arm the closer, and inwardly prayed for strength and power to thrust away from her this dangerous foe, that was creeping on in guise so insidious. (210)

Wood obviously criticises the idea of the angel in the house and demonstrates how impossible it is to fulfil this role. Through the example of Isabel, Wood reveals the dangers if women are not allowed or not able to express themselves. Isabel had married without love, because there was no other choice for a woman in her position. As a married woman, she suffers not only from jealousy, but also from isolation, boredom, lack of money, and powerlessness. "Her frustration and 
depression is obviously enforced by the strictness of her role, which prohibits women from expressing their sexual feelings." (Sterner 201-202)

By taking away from them any chance to keep themselves busy with useful tasks, by forcing them to comply with the symbolic, they ultimately take away their will to live. They settle for convenience and repressed feelings, by putting them on a pedestal and keeping them as a decorative object: the angel in the house fades away and eventually dies. She also points out that to comply with the symbolic inevitable results in a shadowy existence for women. Thus, Isabel's biggest flaw in the first half of the book is to marry out of convenience and not out of love. Wood hints that where passion is absent, mere goodness is not enough. Accordingly, the main criticism is of oppressive, social conventions and of Carlyle who fails to perceive her misery.

\subsection{Carlyle: Failing of Patriarchy}

As various critics have already pointed out Carlyle stands for the epitome of Victorian middle-class values. He has been described as "uncomplicated, sensible, rational, cautious, moderate" as a "good citizen" who is "kind and involved in his work" (A. Kaplan 40). Furthermore, his "solid, respectable manliness, rationality, calmness in the face of turmoil, control in face of loss and crisis, dedication to work and service to community" constitute him as a rational rather than emotional man (A. Kaplan 44). Wood describes him as follows:

He was a very tall man of seven-and-twenty, of remarkable noble presence. He was somewhat given to stooping his head when he spoke to any one shorter than himself; it was a peculiar habit, almost to be called a bowing habit, and his father had possessed it before him, when told of it, he would laugh, and say he was unconscious of doing it. His features were good, his complexion was pale and clear, his hair dark, and his full eye-lids drooped over his deep grey eyes. Altogether it was a countenance that both men and women liked to look upon, the index of an honourable, sincere nature; not that it would have been called a handsome face, so much a pleasing and distinguished one. (7)

Where Levison is described as attractive and beautiful, Carlyle's advantages lie in his character. Pykett, however, points out that "although he is the very model of "manly" honour and restraint, he occupies an ambiguous gender position", since he is "initially dominated by his competent, combative and masculine half-sister Cornelia" (120). Moreover, he is "consistently blind to the tension in his own home" (120). Pykett defines two reasons that explain his blindness and reveals his share of blame on Isabel's fate: 
This [blindness] is partly, because he is, as a man, presumed to be inherently incapable of fathoming the mysteries of the domestic sphere, and partly because he is frequently absent from it and habitually preoccupied with the concerns of the masculine world of work. In other words, Carlyle demonstrates a structural masculine incomprehension of the domestic: the novel implies that men's position within the family simply does not equip them to read the signs of the domestic sphere ... . In this respect he is seen as, to some extent, responsible (through ignorance and inefficacy) for Isabel's dilemma. (120)

Pykett concludes: "The well-intentioned, but ignorant and hence unsympathetic husband, is in part responsible for a difficult domestic situation for which his wife pays the price of banishment and exile" (120).

McCusky comments that East Lynne warns of the dangers of the separate spheres, as Carlyle's strict separation of the public and domestic sphere eventually results in the destruction of his family. This destruction is brought upon through the privacy that is thus gained, as it produces "secrecy, silence, and reserve" that "too often upset the personal relations upon which the community itself depends on" (372). His professional reserve estranges him from his wife. Although his secret meetings with Barbara are innocent, Mangham notes, "his resolution to keep his private and professional lives separated (by not telling Isabel) leads his wife to suspect he is having an affair" (134) which results in her running off with Levison. He hardly ever expresses his emotion a fact that makes Isabel insecure of his love to her. She tries to confront him:

"What is it that she wants with you so much, that Barbara Hare?"

"It is a private business, Isabel. She has to bring me messages from her mother."

"Must this business be kept from me?"

He was silent for a moment, considering whether he might tell her. (258)

He eventually decides against it and thus gives Isabel ground for questioning his faithfulness:

She did not put faith in a word of the reply. She believed he could not tell her because her feelings, as his wife, would be outraged by the confession: and it goaded her anger into recklessness. Mr Carlyle, on his part, never gave a thought to the supposition that she might be jealous: he had believed that nonsense at an end years ago. He was perfectly honourable and true, giving her no shadow of cause or reason to be jealous of him: and, being a practical, matter-of-fact man, it did not occur to him that she could be so. (258)

Wood obviously questions the strict division of the spheres and the resulting lack of complicity between men and women. She points to its dangers, as misunder- 
standings can easily occur. Mangham continues by pointing out that although Carlyle is "hardly the deceptive tyrant" the "lack of communication between him and Isabel (as augmented by his professional status) is a significant factor in the breakdown of his marriage" (136).

Furthermore, A. Kaplan argues that Isabel seeks a "satisfaction of a passionate, merging feeling" that she experiences a "desire for the loss of the self in the Other" (38). Carlyle's calm, distanced and rational character prevent such a kind of merging. Levison's seductiveness, on the other hand, and "his own desire to possess [her] make such a projection easy" (38). As Isabel stands to Carlyle as a child to a wise and overawing father, she is afraid of telling Carlyle of her attraction to Levison or of Cornelia's abuses; she is unable to reveal her secrets:

[His] strong arm of shelter round her; a powerful pillar of protection, him upon whom she leaned; why did she not confide herself to him as trustingly as a little child? Simply because her courage failed. Once, twice, the opining words were upon her lips, but come forth they did not; and then the carriage stopped at East Lynne, and the opportunity was over. (225)

McCusky comments here that "again and again the failure to speak candidly, even from the best of motives, ultimately erodes individual trust and leads to disaster" (372).

Langbauer also notes Carlyle's shortcomings, although Wood obviously tried to create the "perfect" male, which she "pieced together by changing emphasis on old literary clichés of gender", thus, she "makes him authoritative, say, rather than overbearing" (240). Although Carlyle fails in the end to live up to the idea of the 'perfect' male, Wood's attempt to create a different character demonstrates the need to do so: "[The] attempt to transform what may be an inevitable patriarchal grammar through new inflections reveals the oppressiveness of its categories even while failing to transform them" (240). Thus, East Lynne implies that Carlyle's bourgeois standard of living is the true cause of Isabel's fall. Pykett comments that in sensation fiction "men and women are shown as being foreign countries to each other ... In such narratives marriage, the presumed site of union and mutual understanding, is revealed as, in fact, a state of mutual isolation, secrecy, and misunderstanding" (50). This notion can obviously be applied to Carlyle's and Isabel's marriage.

\subsection{The Byronic Hero as the Seductive Villain}

When Isabel finally gives in to her passion for Levison, she is governed by enraged feelings of jealousy and revenge on seeing Carlyle and Barbara together in the dark. Levison, who is with Isabel, finally reveals his true colours by supporting Isabel's suspicion through lies. He tells her that he saw her husband and Barbara Hare enjoying a tête-à-tête by moonlight (271). His role as an evil seducer, a vilified 
dandy, becomes now apparent. In contrast to other Regency dandies in the Silverfork novels, however, Levison tastelessly overdresses: "He would wear diamond shirt-studs, diamond pins; brilliants, all, of the first water" (55). Additionally, he would put perfume on his gloves; he is a man full of excesses.

The following passage characterises Isabel's feelings as explosive and energetic; accordingly, at that moment of uncontrolled passion, she stands in the semiotic realm.

Lady Isabel almost gnashed her teeth; jealous doubts which had been tormenting her all evening were confirmed. That the man who she hated - yes, in her blind anger, she hated him then - should so impose upon her, should excuse himself by lies, lies base and false, from accompanying her, on purpose to surpass the hours with Barbara Hare! Had she been alone in the carriage, a torrent of passion had probably escaped her. (271)

Isabel's feelings are portrayed as a 'torrent' that requires an explosive outlet. Levison takes advantage of the situation and begins his seduction of Lady Isabel; in this scene his dangerous nature is described at length:

$\mathrm{He}$, that bold bad man, dared to put his arm around her; to draw her to his side; to whisper that his love was left to her, if another's was withdrawn. She was most assuredly out of her senses that night or she never would have listened.

A jealous woman is mad; an outraged woman is doubly mad; and the illfated Lady Isabel truly believed that every sacred feeling which ought to exist between man and wife was betrayed by Carlyle.

"Be avenged on that false hound, Isabel. He was never worthy of you. Leave your life of misery, and come to happiness."

In her bitter distress and wrath, she broke into a storm of sobs. Were they caused by passion against her husband, or by these bold and shameless words? Alas! alas! Francis Levison applied himself to soothe her with all the sweet and dangerous sophistry of his crafty nature. (271)

Consequently, Isabel does both: she listens to Levison's false promises and gives in to her own sexual desires. The affair however, is only short lived. After he conquers her, he loses all interest in Isabel. They elope to France where he leaves her alone for most of the time, and Isabel quickly starts to regret her action. Her sexual desire soon dies away and is replaced by a growing repulsion. In his meaningless cruelty, he confesses that he has lied to her and that she had never really had a reason to doubt her husband's faithfulness. Although he had promised to marry her when she got pregnant, she finds out that he has no intention to do so and that her child will be illegitimate. As soon as Levison inherits his long awaited title and fortune, he abandons Isabel completely. At this point, she has already stopped caring for herself but she still hopes that he will be willing to marry her for their 
child's sake. When her hope is crushed, she finally decides to leave him. Wood thus demonstrates how differently the power relations between men and women are apportioned. Isabel depends solely on Levison's willingness to marry her in order to be able to be rehabilitated and to legitimaize their child. Levison, on the other hand, has neither responsibility nor obligations towards Isabel.

Lutz notes that the persona of the purely evil seducer is the Victorian version of the dangerous lover. In the middle of the century, the evil seducer was a very prominent figure in stories serialised in magazines. Usually, the narrative would present an aristocrat who would seduce a lower-class girl, generally to ruin and leave her. Where a typical Byronic hero would feel remorse after his evil deed and seek repentance, the newly evolved evil seducer is stripped of any Byronic characteristics except for his appearance and his fatality. Moreover, unquestionably he does not regret his malicious deeds. Lutz argues that this development can clearly be seen a "class allegory and certainly as a reaction against the Byronic hero" (76). She continues by pointing out that the "narratives represent the dangerous lover not as an unquiet soul searching for absolution or death, but rather as only dangerous (but still titillating in his dangerousness)" (76). He ultimately becomes a mere source of harm for those around him.

Lucas' review of East Lynne in The Times focuses upon Wood's representation of Sir Francis Levison, rather than on Lady Isabel's story. Lucas argues that this is one of the better sensation novels, yet is puzzled as to why Wood should heap so much ignominy on Levison's head:

$[\mathrm{H}] \mathrm{e}$ is hated and despised by all his acquaintance, not expecting even the woman he espouses [...] All this crime and retribution for an ordinary performer who is merely up to the standard of a walking gentleman is excessively onerous, and we know of few cases in fiction of such rigorous treatment as that of Sir Francis Levison.(6)

One expects Levison to be punished for his seduction of Lady Isabel, yet the extensive list of humiliations he faces before he finally ends his days in prison is, as Lucas suggests, unusual in fiction. The didactic undertone of Levison's seduction of Lady Isabel reveals that the idleness, wastefulness and cruelty of such men are harmful to society as a whole; his punishment needs to make an example. There is no purpose behind his seduction of women which leads to the destruction of families. Lutz comments that he

does these things without any sort of magnetism, personal power, or clear desire. As a purely transgressive force, he still does not create a serious rift or interruption in given norms, as a rebellious Romantic would seek but rather serves to uphold the generally understood moral structure based on heterosexual marriage and monogamy. (76-77) 
In contrast to the Romantic rebel, the evil seducer does not want to change social norms:

The Victorian antihero, on the contrary, can always be recuperated into a heterosexual discourse of crime and punishment. He may stand out starkly in his dangerous eroticism initially, but as the novel draws to a close, he is punished, chastened, and somehow brought under the shadow of propriety. (77)

Thus, in the end Levison is convicted of the murder he tried to pin on Richard Hare and is sentenced to be shipped overseas where he is condemned to hard labour. Although he cannot be legally punished for his seduction of Lady Isabel, he is hated by all for his evil deed and shunned by society; even his own wife is not sorry to have seen the last of him. Wynne points out that Levison's downfall and humiliation is completed when he is "denied the "dignity" of death when he is found guilty of murder" but punished to hard work (77).

Accordingly, unlike the original Byronic hero who falls and survives as failure, the evil-seducer character, like Levison, must be punished when confronted with his crimes.

\subsection{Madam Vine: The Suffering Heroine}

Through her elopement, Isabel forfeits not only home and family, but also her social position, and self-respect as well. She learns in a devastating way that her desire for sexual fulfilment is impossible, as Levison emerges as the villain. Her punishment for giving in to her sexual desires and forgetting any morality is instantaneous, as Levison soon starts to neglect her, refuses to marry Isabel and to make their child legitimate. The overt didacticism and moral implication used by the narrator to tell the second part of Isabel's story, a story of suffering and remorse has been interpreted in different ways. Thus Wynne argues that "Isabel's downfall gives Wood and middle-class readers a pretext to gloat over the downfall of aristocracy" (67). She continuous by arguing that "Barbara, with her bourgeois values of prudence and propriety, eventually replaces the frail, childlike Lady Isabel" and although

the reader is encouraged to feel sympathy for her dilemma [nevertheless] Wood's focus upon her suffering and in particular the obvious delight she takes in detailing her mutilated body and agonies of remorse, lets suggest that she experienced a range of complex response to Isabel, including a covert satisfaction in witnessing the downfall of aristocracy. (69)

Wynne reduces Isabel's story to Wood's aversion against the aristocracy and her delight in portraying its downfall. However, this is too simplistic a reading of East Lynne, as there is much more to it than class rivalry. 
Critics like Mangham argue that one of the main motifs of the novel is the failure of the family, which "appears to hinge, almost entirely, on the ungovernable passions of the wife and mother Isabel" (129) and the threat Isabel's elopement presents to the nuclear family. Furthermore, he comments that the moral tone of the narrator "echoes mid-Victorian, conformist claims that the control of female emotion is crucial to the health and preservation of the middle-class way of life" (132). A. Kaplan joins Mangham and Wynne when she argues both that the narrator clearly "serves patriarchy in her severe critique of female desire" and at the same time endorses the new middle-class family" (46). She continues by pointing out that only the middle class is able to keep a balance between desire and its release in the novel. Furthermore, she argues that the main critique lies on desire and "the necessity of control a socially inscribed desire"; more specifically "it is especially female desire that is the problem and in the case of Isabel ... [her] desire brings about disaster" (47). A. Kaplan does not perceive Levison as the evil seducer who takes advantage of Isabel's misery but merely as "the willing and available vessel for evoking and receiving their sexual desire" (47). As has been demonstrated, those readings of the novel are obviously too partial and alternatives need to be considered.

Isabel loses her illegitimate child in a train accident and is herself disfigured beyond recognition. She is wounded so severely that the doctors have no hope for recovery and a notice containing the announcement of her death is sent to the papers. Taking the name of Madam Vine, she supports herself as a governess. Overwhelmed with the longing for her children, she returns to England to take up the position as governess to her own children. In England, at her old home, is where her punishment really starts. She does not only suffer from the loss of place in her family but she has to watch the Carlyle's and Barbara's marital bliss, and instead of motherly love she has to give her own children the cool attention of a governess.

The narrator explicitly urges the audience to learn from her mistake:

Never had she experienced a moment's calm or peace, or happiness, since the fatal night of quitting her home. She had taken a blind leap in a moment of wild passion; when, instead of the garden of roses it had been her persuader's pleasure to promise her, (but which, in truth, she had barely glanced at, for that had not been her moving motive), she had found herself plunged into an abyss of horror from which there was never more any escape... a lively remorse, a never-dying anguish, took possession of her soul forever. O reader, believe me! Lady - wife - mother! should you ever be tempted to abandon your home, so you will awake! Whatever trials may be the lot of your married life, though they may magnify themselves to your crushed spirit as beyond the endurance of woman to bear, resolve to bear them; fall down on your knees and pray to be enabled to bear them: pray for patience: pray for strength to resist the demon that would urge you so 
to escape; bear unto death, rather than forfeit your fair name and your good conscience; for be assured that the alternative, if you rush on to it, will be found far worse than death. (283, my emphasis).

This moral prescription of purity, duty, obedience, and conformity describes the constricted role of the Victorian woman. Consequently, the urgency of this message suggests that "she felt herself speaking to a large and desperate audience" (Showalter 1999, 172). The sympathy and identification female readers felt with Lady Isabel led simultaneously to a rejection of the "perfect" Barbara. Margaret Oliphant, for example, could far more identify with Isabel's plight than with Barbara's propriety:

When [Isabel] returns to her former home under disguise of the poor governess, there is not a reader who does not feel disposed to turn her virtuous successor to the door, and reinstate the suffering heroine, to the glorious confusion of all morality. (170)

Furthermore, it has been argued that Wood intended her pitiable heroine as an object lesson to other women. Although a sympathetic, it is nevertheless a powerful one, as it is considered as a lesson "in the necessity of suppressing sexual desire and passion" (Introduction to Ellen Wood, 152). Critics argue that Wood's attitude towards this subject is apparent: a woman who leaves her husband for another man must necessarily suffer the consequences. This is part of a providentially designed pattern, in which good is repaid and evil punished. Isabel's misfortunes are an accurate representation of the dilemma of Victorian women. According to Showalter, the story:

expresses the sense of hopeless dependency, the lack of alternatives in the lives of Victorian gentlewomen. Detail by detail, Mrs. Wood builds up her case study of women's position in a patriarchal society ... Mrs. Wood condemns her heroine's weakness and folly, but also gives the reader a sympathetic documentary of Lady Isabel's empty hours, her loneliness, isolation, and hopelessness ... ("Family Secrets" 110)

Showalter continues by pointing out that although Wood "adopts a moral and prudential tone" she nevertheless "clearly sympathizes with the wife who is neither deceived nor mistreated but sexually frustrated and bored to death" (1999, 172). Sterner supports this statement when he argues: "[Isabel] falls due to her own feminine weakness, her inability to live up to the Victorian woman's idealization" (200). Thus, unrealizable demands were the reason for her failure. 


\subsection{Conclusion}

To argue that East Lynne is intended as an example for women to demonstrate the necessity to suppress their sexual desires as their acting out would only end in disaster is to disregard Wood's obviously sympathetic treatment of Isabel's dilemma. Although Isabel's passions are the reasons for the destruction of her family, the text implies that the shortcomings of Carlyle, embodiment of the ideal of bourgeois masculinity, are responsible for Isabel's fall. Even though readers should reject Isabel for her actions, both the description of her marital misery and the detailed depiction of her repentance lead to a questioning of the restricting social convention. Her fading away within the symbolic left her no choice than to break out, as it would have led to her certain death.

The representation of masculinity in East Lynne is reduced to only two models. Firstly, the good but morally overwhelming father, up to which standards Isabel cannot live. Secondly, the villainous lover, who ruins her. The Byronic hero, although the trigger and catalyst of her sexual desire, is here stripped of every Romantic notion and presented as a shallow, evil seducer, whose villainy knows no end. In the second part of the novel, Levison's villainy is emphasised. He is portrayed as an experienced seducer and eventually revealed as a murderer. Thus, Isabel is more and more perceived as a victim. Wood's portrait of Isabel's character and the description of her marital relationship lead to sympathy and pity, not to a condemnation of the heroine.

The dialogism of the text, meaning the subversive sub-text that arises from the circumstance that Wood wants the reader to think two contradictory things at once, to condemn and to identify with Lady Isabel, is clearly intended as a critique on the patriarchal system. This points to Wood's intentions, both to criticise the strict social conventions for women and the shortcomings of masculinity. In this way, East Lynne challenges the very norms it seems to support and pictures the contradictions of the ideal woman.

\section{Conclusion}

Through their novels, Lady Caroline Lamb, Charlotte Brontë and Ellen Wood, three female writers, partake in the chief debate of their age, the debate between rights and duties. By means of characters and plot, these women writers express their view in the debate. They criticise and condemn ideals and values of a society dominated by the ideology of patriarchy and its oppressive stance towards women. All three demonstrate, in similar ways, the severe consequences of an ideology that demands the repression of female desire and total female submissiveness. Where Lamb and Wood reveal by the examples of Calantha and Isabel how under the surface a torrent of repressed and denied desire is only barely re- 
strained, Brontë creates a heroine who refuses to be dominated by a tyrannical ideology.

Julia Kristeva's declaration of the interdependency of the symbolic and symbiotic is correct, as none of the female characters is able to comply with one order only. The attempt either leads to self-destruction (Helen), madness (Bertha), or an unrestrained shift to the semiotic (Calantha, Elinor, and Isabel), which eventually ends in death. Even Jane, the most emancipated and independent of these women and the only one who is able to balance the two orders and therefore rewarded with a happy ending, has difficulties in not losing her identity in the semiotic (Rochester) or symbolic (St. John River).

A notable parallel between the novels is the means by which women are confronted with the semiotic; namely through the appearance of the Byronic hero. The interpretation of this literary persona depends on which image of Lord Byron influenced the novelists, such as the real man Byron, the heroes of his poetry, his myth, or a mixture of the three. It also depends on the decade the writer was living in. Where Lamb and Brontë approach the Byronic hero from a more Romantic view, Wood applies a strict moral code on him, strips him of anything Romantic and depicts him as a shallow, evil seducer. Nevertheless, each of these female writers use the Byronic hero as a critique on restricting gender roles, as his appearance presents the hopelessness of the situation in which women are located in. Within the dominant ideology of patriarchy, female sexuality, which simply cannot be repressed completely, is considered unsustainable and unacceptable. There is no place for desiring women in society, thus the only consequences for them are either isolation (Jane) or death, as the examples of Calantha, Elinor, Helen, Bertha, and Isabel clearly demonstrate. Lamb, Brontë, and Wood draw on the Byronic hero's function as a fatal lover, who overpowers and in most cases destroys the women he encounters, to draw attention to the female dilemma.

The popularity of the Byronic hero nowadays is indisputable; he is found in a vast number of novels and movies, all resulting in a happy ending. Most notably, his role as a brooding vampire is steadily gaining popularity. However, he is no longer used as a means of criticism but as a romantic object of female desire. This transformation still needs to be explored. 


\section{Bibliography}

Primary Literature

Baillie, Joanna. A Series of Plays: In Which It Is Attempted to Delineate the Stronger Passions of the Mind. London, 1789

Brontë, Charlotte. Jane Eyre. Ed. Richard J. Dunn. New York: W.W. Norton \& Company, 1987.

Byron, George Gordon Noel, Baron (2009). Byron's Poetry and Prose. Select. nd ed. Alice Levine. New York: W.W. Norton, 2009.

Lamb, Lady Caroline. The Whole Disgraceful Truth: Selected Letters Lady Caroline Lamb. Ed. Paul Douglass. New York: Palgrave McMillain, 2006.

Shelley, Percy. "On the Medusa of Leonardo da Vinci", "To the Skylark."The Complete Poems of Percy Bysshe Shelley. New York:The Modern Library of New York, 1994. 621; 640.

Wood, Ellen. East Lynne. Ed. Jay, Elisabeth. New York: Oxford University Press, 2008.

Secundary Literature

Airlie, Mabell Countess of. In Whig Society 1775-1818, Compiled from the Hitherto Unpublished Correspondence of Elizabeth, Viscountess Melbourne, and Emily Lamb, Countess. Cambridge: Scholar Publishing, 2010.

Barry, Peter. Beginning Theory: An Introduction to Literary and Cultural Theory. Manchester: Manchester UP, 2009.

Henry Blyth. Caro: The Fatal Passion. New York: Haper Collins, 1972.

Braudy, Leo. The Frensy of Renown: Fame and its History. Oxford: Oxford UP, 1986

Bronfen, Elisabeth. Over Her Dead Body: Death; Femininity and the Aesthetic. Manchester: Manchester UP, 1992

Butler, Eliza Marian. Byron and Goethe: Analysis of a Passion. Nottingham: Nottingham University College, 1992.

Chase, Richard. "The Brontës, or Myth Domesticated." in Forms of Modern Fiction. Essays Collected in Honor of Joseph Warren Beach. Ed. William Van O'Connor. Minneapolis: Univ. of Minnesota Press, 1948.102-119.

Cho, Sonjeong. An Ethics of Becoming: Configuration of Feminine Sexuality in Jane Austen, Charlotte Brontë and George Eliot. New York: Routledge, 2006. 
Cixous, Hélène. "The Laugh of the Medusa," trans. Keith Cohen and Paula Cohen, Signs 1.4 (1976).

Clarke, Michael M.. “Brontë's Jane Eyre and the Grimm's 'Cinderella”'. Studies in English Literature, 1500-1900. 40.4 (Autumn 2000): 695-710.

Clubbe, John. "Glenarvon Revised - and Revisited". The Wordsworth Circle 10.2 (1979): 205-217.

Craciun, Adriane, ed. Mary Wollstonecraft's A Vindication of the Right of Woman: $A$ Sourcebook. London: Routledge, 2000.

Cvetkovich, Ann. Mixed Feelings: Feminism, Mass Culture, and Victorian Sensationalism. New Brunswick: Rutgers UP, 1992.

Davidoff, Leonore, Catherine Hall. Family Fortunes: Men and Women of the Middle Class 1780-1850. London: Routledge, 1987.

Dickerson, Vanessa. Victorian Ghosts in the Noontide: Women Writers and the Supernatural. Columbia, Mo: UP of Missouuri, 1996.

Douglass, Paul. “The Madness of Writing: Lady Caroline Lamb’s Byronic Identity". Pacific Coast Philology 34.1, (1999). 53-71.

— "Introduction." The Works of Lady Caroline Lamb. Pickering \& Chatto, 2009. xxvii-xlv.

Eagleton, Terry. Myths of Power. Basingstoke: Palgrave Macmillan, 1975.

Elfenbein, Andrew. Byron and the Victorians. Cambridge: Cambridge UP, 1966.

Ewbank, Inga-Stina. Their Proper Spheres: A sSudy of the Brontë Sisters as early- Victorian Female Novelists. London: Arnold, 1966.

Francis, Jeffrey. The Romantics Reviewed. Contemporary Reviews of British Romantic Writers. Part B. 5 vols. Ed. Donald H. Reiman. New York: Garland, 1972. 2:837.

Franklin, Caroline. "Introduction.” Glenarvon: Volume I, by Lady Caroline Lamb. London: Routledge/Thoemmes Press, 1995: v-xxii.

Gérin, Winifred. “Byron's Influence on the Brontë's." Keats-Shelley Memorial Bulletin 15,(1966): 1-20.

Gilbert, Sandra and Susan Gubar. "A Dialouge of Self and Soul: Plain Jane’s Progress." The Brontë Sisters: Critical Assessments.3 vols. Evaluation of the Novels: Agnes Grey, Wuthering Heights and The Tenant of Wildfell Hall. Ed. Eleanor McNees. Mountfield: Helm Information, 1996. 254-283.

Gleadle, Kathryn. British Women in the Nineteenth Century. Basingstoke: Palgrave Macmillan, 2001.

Graham, Pete. Don Juan and Regency England. Charlottesville: UP of Virginia, 1990.

Grosskurth, Phyillis. Byron: The Flawed Angel. London: Hodder \& Stoughton, 1997.

Grossman, Lev. "Stephenie Meyer: A New J.K. Rowling?" Time U.S. Online, n.pag. 24. April 2008. 
Habermas, Jürgen. The Structural Transformation of the Public Sphere: An Inquiry into a Category of Bourgeois Society. Cambridge, Massachusetts: The MIT Press, 1989.

Harrison, Kimberly and Richard Fantina, eds. Victorian Sensations: Essays on a Scandalous Genre. Columbus, Ohio: Ohio State UP, 2006.

Hendershot, Cyndy. The Animal Within: Masculinity and the Gothic. Ann Arbor, Mich.: UP of Michigan, 1998.

Jaquet, Alison. "The Disturbed Domestic: Supernatural Spaces in Ellen Wood's Fiction." Women' Writing 15:2 (2008): 244-258.

Jenkins, Elisabeth. Lady Caroline Lamb. London: Cardinal, 1974.

Judson, Barbara. "Roman à Clef and the Dynamics of Betrayal: The Case of Glenarvon." Genre: Forms of Discourse and Culture 33.2 (2000): 151-69.

Kaplan, Ann. "The Political Unconscious in the Maternal Melodrama: Ellen Wood's East Lynne." Gender, Genre and Narrative Pleasure. Ed. Derek Longhurst. London: Unwin Hyman, 1989. 31-50.

Kaplan, Carla. The Erotics of Talk: Women's Writing and Feminist Paradigms. New York: Oxford University Press, 1996.

Kelly, Gary. Women, Writing, and Revolution 1790-1827. London: Clarendon Press, 1993.

Kelsall, Malcolm. "The Byronic Hero and Revolution in Ireland: The Politics of Glenarvon.” Byron: Poetry and Politics: Seventh International Byron Symposium, Salzburg 1980. Ed. Erwin A. Stürzl and James Hogg. Salzburg: Inst. für Anglistik \& Amerikanistik, Univ. Salzburg, 1981. 137-151.

Knapp, Steven. Personification and the Sublime: Milton to Coleridge. Cambridge: Harvard University Press, 1985.

Kristeva, Julia. "The System and the Speaking Subject." The Kristeva Reader. Ed. Toril Moi. New York: Columbia UP, 1986. 24-34.

— "Revolution in Poetic Language." The Kristeva Reader. Ed. Toril Moi. New York: Columbia UP, 1986. 89-137.

Lacan, Jacques. The Seminar of Jaques Lacan, Book II: The Ego in Freud's Theory and in the Technique of Psychoanalysis, 1954-1955. Ed Jaques-Alain Miller. New York: Norton, 1985.

Lamb, Lady Caroline. Glenarvon. Ed. Deborah Lutz. Kansas City: Valancourt Books, 2007.

Lambert, Elisabeth Zetzel. The Face of Love: Feminism and the Beauty Question. Boston: Beacon Press, 1995.

Langbauer, Laurie. "Women in White, Men in Feminism." Yale Journal of Criticism, 2:2 (1989 Spring): 219-243.

Liggins, Emma, and Andrew Maunder. "Introduction: Ellen Wood, Writer." Women's Writing, 15:2 (2008): 149-156. 
Light, Alison. Forever England: Femininity, Literature and Conservatism between the $W$ ars. London: Routledge, 1991.

Lodge, David. Language of Fiction. London: Routledge, 1966.

Lucas, Samuel. "Review of East Lynne.” Times, 25 January 1862, 6.

Lutz, Deborah. The Dangerous Lover: Gothic Villains, Byronism, and the NineteenthCentury Seduction Narrative. Columbus: Ohio State University Press, 2006.Mangham, Andrew. Violent Women and Sensation Fiction: Crime, Medicine and Victorian Popular Culture. Basingstoke: Palgrave Macmillan, 2007.Maunder, Andrew. "'Stepchildren of Nature': East Lynne and the Spectre of Female Degeneracy, 1860-1861." Victorian Crime, Madness and Sensation. Ed. Andrew Maunder and Grace Moore. Aldershot: Ashgate, 2004. 59-71.

Maynard, John. Charlotte Brontë and Sexuality. Cambridge: Cambridge University Press, 1984.

McCuskey, Brian W. "The Kitchen Police: Servant Surveillance and Middle-Class Transgression." Victorian Literature and Culture 28.2 (2000): 359-75.

McDayter, Ghislaine. Byromania and the Birth of Celebrity Culture. Albany, NY: State University of New York Press, 2009.

— "Hysterically speaking: Lady Caroline Lamb's Glenarvon.” Romantic Generations: Essays in Honor of Robert F. Gleckner. Ed. Ghislaine McDayter, et al. London, England: Associated UP, 2001. 155-77.

Mei, Huang. From Fanny Burney to Charlotte Brontë: The Transformation of a Dream. Ann Abhor, Mich.: Univ. Microfilms Internat., 1989.

Meyer, Stephenie. Twilight. London: Atom, 2007.

Millgate, Jane. "Narrative Distance in Jane Eyre: The Relevance of the Picture." Modern Language Review, 63 (1968): 315-319.

Mitchell, Maera, and Dianne Osland. Representing Women and Female Desire from Arcadia to Jane Eyre. Basingstoke: Palgrave Macmillan, 2005.

Mitchell, Sally. The Fallen Angel: Chastity, Class and Women's Reading 1835-1880. Bowling Green: Bowling Green University Popular Press, 1981.

— "Sentiment and Suffering: Women's Recreational Reading in the 1860s." Victorian Studies, 21:1 (1977:Autumn):29-45.

Moglen, Helene. Charlotte Brontë: The Self Conceived. New York: Norton, 1976.

Morgan, Simon, “'A Sort of Land Debatable': Female Influence, Civic Virtue and

Middle-Class Identity, c.1830-c.1860.” Women's History Review 13, 2 (2004), 183-209.

Oliphant, Margaret. "Modern Novelists-Great and Small." Blackwood's Edinburgh Magazine, 77 May (1855): 557-59.

— “Novels.” Blackwood's Magazine, 94, (August 1863): 170.

Olney, Clarke. "Glenarvon Revisited." University of Kansas City Review, 22 (1956): 271-276. 
Paston, George and Peter Quennell. "To Lord Byron”: Feminine Profiles based upon unpublished letters 1807-1824. London: Murray, 1939.

Perkins, David. English Romantic Writers. New York: Harcourt \& World, 1967.

Pesta, Duke. "Darkness Visible': Byron and the Romantic Anti-Hero." Lord Byron. Ed. Harold Bloom. Philadelphia: Chelsea House Publishers, 2004.. 5985.

Pinch, Adela. Strange Fits of Passion. Epistemologies of Emotion, Hume to Austen. Stanford: Stanford University Press, 1996.

Praz, Mario. The Romantic Agony. London: Oxford University Press, 1933.

Pykett, Lyn. The Improper Feminine. London: Routledge, 1992.

Railo, Eino. The Haunted Castle: A Study of the Elements of English Romanticism. New York: Gordon Press, 1927.

Reynolds, Kimberly and Nicola Humble. Victorian Heroines: Representation of Femininity in Nineteenth-Century Literature and Art. New York: New York Press, 1993.

Rogers, Samuel. Table Talk. New York: Appleton, 1856.

Rousseau, Jean-Jaques. Emile, or On Education (1762). Translated and introduced by Allan Bloom. New York: Basic Books, 1979.

Scott, Walter, "Review of Childe Harold's Pilgrimage, Canto III", in The Quarterly Review 16 (October 1816-January 1817): 172-206.

Showalter, Elaine. "Family Secrets and the Domestic Subversion." The Victorian Family. Ed. Anthony S. Wohl. London: Croon Helm, 1978.

- A Literature of Their Own: From Charlotte Brontë to Doris Lessing. London: Virago, 1999.

- A Literature of Their Own: From Charlotte Brontë to Doris Lessing. London: Virago, 2009.

Smith, Margaret, ed. The Letters of Charlotte Brontë: With a Selection of Letters by Family and Friends, Volume II. 1816-1855. Oxford: Clarendon Press, 2000.

Solderholm, James. "Lady Caroline Lamb: Byron's Miniature Writ Large.” KeatsShelley Journal: Keats, Shelley, Byron, Hunt, and Their Circles, 40 (1991): 24-46.

Sterner,Mark. "The Changing Status of Women in Late Victorian Darama." Within the Dramatic Spectrum. Ed. Karelisa Hartigan. Lenham: University Press of America, 1986. 199-212.

Tuite, Clara. "Tainted Love and Romantic Literary Celebrity." ELH 74.1 (2007): 59-88.

Torslev, Peter Larson. The Byronic Hero: Types and Prototypes. Minneapolis, Minn.: University of Minnesota Press, 1962. 